\title{
DOSES DE NITROGÊNIO E DE MAGNÉSIO AFETANDO ASPECTOS PRODUTIVOS E BIOQUÍMICOS DOS CAPINS COLONIÃO, TANZÂNIA-1 E VENCEDOR
}

\author{
BEATRIZ DIAS CORRÊA \\ Engenheira Agrônoma
}

Orientador: Prof Dr. Francisco Antonio Monteiro

Dissertação apresentada à Escola Superior de Agricultura "Luiz de Queiroz", da Universidade de São Paulo, para obtenção do título de Mestre em Agronomia, Área de Concentração: Ciência Animal e Pastagens.

PIRACICABA

Estado de São Paulo-Brasil

Novembro-1996 


\section{DOSES DE NITROGÊNIO E DE MAGNÉSIO AFETANDO ASPECTOS PRODUTIVOS E BIOQUÍMICOS DOS CAPINS COLONIÃO, TANZÂNIA-1 E VENCEDOR}

BEATRIZ DIAS CORRÊA

Aprovada em: 16.12.1996

Comissão julgadora:

Prof. Dr. FRANCISCO ANTONIO MONTEIRO

ESALQ-USP

Prof. Dr. HERBERT BARBOSA DE MATTOS

ESALQ-USP

Prof. Dr. LUÍS ROBERTO DE ANDRADE RODRIGUES

FCAVJ-UNESP

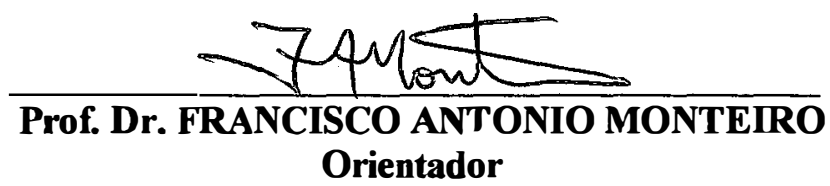


Ao meu pai, a minha mãe "in memorian" e aos meus irmãos e cunhados,

\section{OFEREÇO.}

Ao Alexandre,

DEDICO. 


\section{AGRADECIMENTOS}

Ao Prof. Dr. Francisco Antonio Monteiro pela excelente orientação, pelo apoio e pela amizade desenvolvida.

Ao Prof. Dr. Quirino Augusto de Camargo Carmello, pela amizade, ajuda e sugestões.

Ao Prof. Dr. Antonio Roque Dechen pela amizade e incentivo.

Ao Prof. Dr. Luiz Antonio Gallo pelas sugestões e auxílio prestados para metodologia na determinação da atividade da enzima glutamina sintetase.

A todos os professores do Curso de Ciência Animal e Pastagens pela dedicação e conhecimento transmitidos.

Aos estagiários de Nutrição Mineral de Plantas pela ajuda, dedicação e amizade.

Aos funcionários do Laboratório de Nutrição Mineral de Plantas Edinéia Cristina Scervino Mandoni, Fernando Éder Ré, Lúcia Helena S. P. Forti, Lurdes Aparecida Dário de González, Mirtes Ventura Sesso, Nivanda Maria de Moura e Sueli Maria Amaral Campos Bovi pelo apoio à realização das análises.

Aos funcionários do Centro de Biotecnologia Agrícola- CEBTEC, Enio Tiago de Oliveira e Antonio Francisco de Campos Amaral pelo auxílio nas análises enzimáticas.

Aos companheiros de curso e amigos, especialmente Ana Aparecida da Silva, Anacleto Ranulfo dos Santos, João Batista Rodrigues de Abreu, Júlio César Raposo de Almeida, Maria Cecília Nogueira de Sá Pinto, Renata Aparecida Martim e Waldssimiler Teixeira de Mattos pelo carinho, ajuda e incentivo.

Ao CNPq pelo apoio financeiro e institucional prestado para a realização deste trabalho. 


\section{SUMÁRIO}

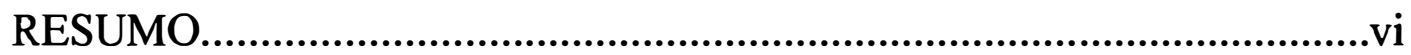

SUMMARY ....................................................................................

1. INTRODUÇÃO....................................................................................

2. REVISÃO DE LITERATURA............................................................

2.1. A espécie Panicum maximum …………………………................. 03

2.2. Nitrogênio em gramíneas forrageiras................................................04

2.3. Magnésio em gramíneas forrageiras..................................................

2.4. Atividade da redutase do nitrato........................................................11

2.5. Atividade da glutamina sintetase.........................................................14

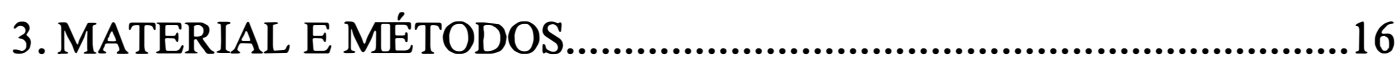

3.1. Condições de instalação e condução do experimento........................16

3.2. Tratamentos, soluções nutritivas e delineamento experimental..........17

3.3. Coleta do material vegetal................................................................17

3.4. Determinações no material vegetal...................................................19

3.5. Análises estatísticas............................................................................

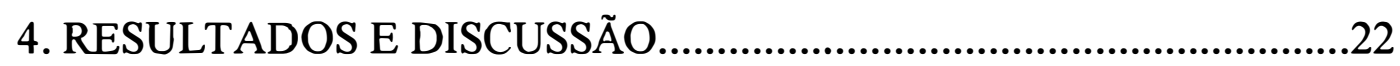

4.1. Produção de matéria seca da parte aérea.............................................22

4.2. Produção de matéria seca das raízes....................................................30

4.3. Número de perfilhos.......................................................................

4.4. Atividade da redutase do nitrato............................................................35 


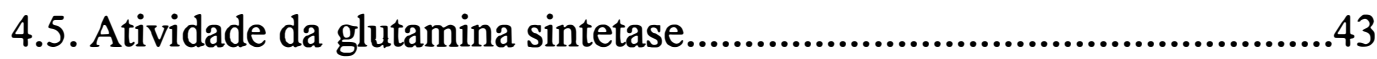

4.6. Concentração de nitrogênio nos tecidos vegetais..............................43

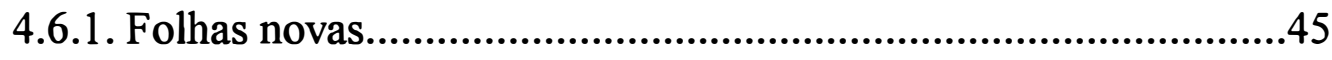

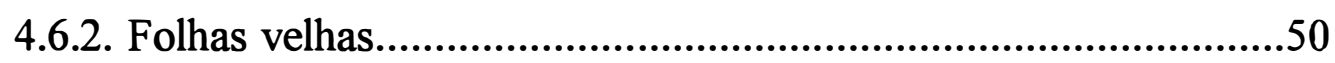

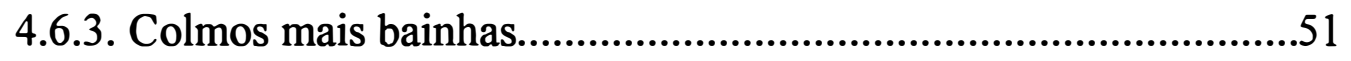

4.7. Concentração de magnésio nos tecidos vegetais...................................54

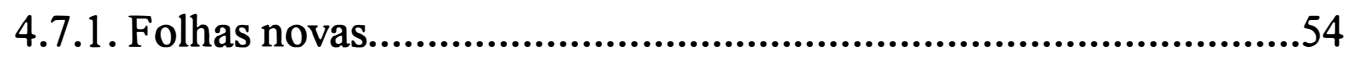

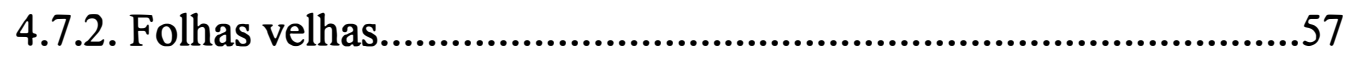

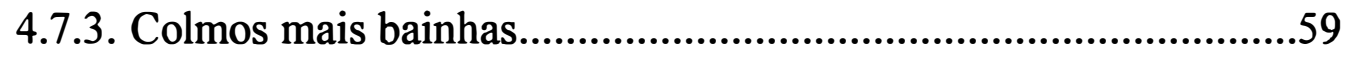

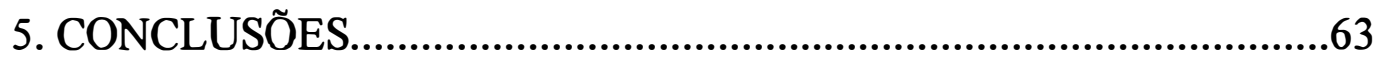

REFERÊNCIAS BIBLIOGRÁFICAS...............................................65 


\title{
DOSES DE NITROGÊNIO E DE MAGNÉSIO AFETANDO ASPECTOS PRODUTIVOS E BIOQUÍMICOS DOS CAPINS COLONIÃO, TANZÂNIA-1 E VENCEDOR
}

\author{
Autor: Beatriz Dias Corrêa \\ Orientador: Prof. Dr. Francisco Antonio Monteiro
}

\section{RESUMO}

Foi realizado um experimento em casa-de-vegetação utilizando solução nutritiva com os cultivares Colonião, Tanzânia-1 e Vencedor de Panicum maximum Jacq, de dezembro de 1995 a fevereiro de 1996, com o objetivo de avaliar o efeito de doses de nitrogênio e de magnésio sobre a produção de matéria seca, perfilhamento, atividade das enzimas redutase de nitrato e glutamina sintetase e concentrações de nitrogênio e de magnésio nas partes das plantas.

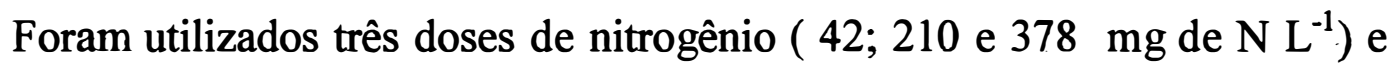
duas doses de magnésio ( 4,8 e $48 \mathrm{mg}$ de $\mathrm{Mg} \mathrm{L}^{-1}$ ). O delineamento utilizado foi o de blocos ao acaso, com quatro repetições, em esquema fatorial $3 \times 2 \times 3$ ( 3 doses de $\mathrm{N}, 2$ doses de Mg e 3 cultivares) perfazendo um total de 72 vasos. A atividade da redutase de nitrato foi determinada, respectivamente, aos 27 e 26 dias no primeiro e segundo crescimento, e a atividade da glutamina sintetase aos 35 e 33 dias. As plantas foram colhidas 35 e 33 dias após a aplicação da solução definitiva, para o primeiro e segundo cortes, sendo separadas em lâminas novas, lâminas velhas, colmos+bainhas. Por ocasião do segundo corte foram também coletadas as raízes.

Os resultados mostraram efeitos significativos das doses de nitrogênio na produção de matéria seca da parte aérea total e das raízes, no número de perfilhos, na atividade da redutase do nitrato e na atividade da glutamina sintetase. As concentrações de nitrogênio e de magnésio nas partes da planta aumentaram com as doses de nitrogênio. A resposta às doses de magnésio 
ocorreram em algumas variáveis. Os cultivares se comportaram de maneira diferente, principalmente quando se utilizou a dose de nitrogênio mais elevada. A atividade da enzima redutase do nitrato variou significativamente com as doses de magnésio, enquanto que a atividade da glutamina sintetase foi alterada pelas doses de nitrogênio. $O$ número de perfilhos aumentou até a dose de $210 \mathrm{mg} \mathrm{L}^{-1}$ de nitrogênio, não variando entre 210 e $378 \mathrm{mg} \mathrm{L}^{-1}$. 
NITROGEN AND MAGNESIUM RATES AFFECTING YIELD AND BIOCHEMICAL ASPECTS OF THE GRASSES COLONIÃO, TANZÂNIA1 AND VENCEDOR

\author{
Author: Beatriz Dias Corrêa \\ Adviser: Prof. Dr. Francisco Antonio Monteiro
}

\title{
SUMMARY
}

An experiment was carried out in nutrient solutions with Colonião, Tanzânia-1 e Vencedor, cultivars of the Panicum maximum Jacq, with the objective of evaluating nitrogen and magnesium rates on dry matter yield, tiller number, nitrate reductase and glutamine synthetase activities and nitrogen and magnesium concentrations in parts of the plants.

The experiment was performed during the summer of 1995-96, in a greenhouse, and ground quartz was used as substrate. Three levels of nitrogen ( 42, 210 e $378 \mathrm{mg} \mathrm{L}^{-1}$ ) and two levels of magnesium ( 4,8 e $48 \mathrm{mg} \mathrm{L}^{-1}$ ) were tested. The experiment was set in a complete randomized block design, with four replications, in a factorial arrangement of $3 \times 2 \times 3$ ( 3 rates of $\mathrm{N}, 2$ rates of $\mathrm{Mg}$ and 3 cultivars). The nitrate reductase activity was determined at 27 and 26 days after the start of the experiment respectively, in the first and second growth period and glutamine synthetase activity at 35 and 33 days. Plants were harvested at 35 and 33 days after starting the use of nutrient solutions for the first and second growth. Plants were separated into young leaves, old leaves, stem+ sheats and roots.

The results showed significant effects of nitrogen rates on dry matter yield, on tillers number, nitrate reductase activity, glutamine synthetase activity and nitrogen and magnesium concentration in plant parts. Responses to magnesium 
rates were observed only in a few parameters. Differences among cultivars were detected mainly at the highest nitrogen rate. Nitrate reductase activity was changed by magnesium rates whereas glutamine sinthetase activity was influenced by nitrogen rates. Tiller number increased up to $210 \mathrm{mg} \mathrm{N} \mathrm{L}^{-1}$ of solution, but no additional changes ocurred when the nitrogen rate was increased to $378 \mathrm{mg} \mathrm{N} \mathrm{L}^{-1}$. 


\section{INTRODUÇÃO}

A nutrição mineral de plantas forrageiras está diretamente relacionada à produção de ruminantes, uma vez que a alimentação básica destes animais ocorre principalmente em pastagens. Assim, a fertilidade dos solos é um dos principais fatores que afeta a produção das plantas forrageiras e portanto a produção animal. A falta de fertilização em pastagens ou a fertilização feita de maneira inadequada provoca baixo rendimento da forragem e degradação precoce dos pastos.

A espécie Panicum maximum Jacq., utilizada no Brasil, é originária da África Tropical e foi introduzida em inúmeros países do mundo. $\mathrm{O}$ cultivar colonião é uma das forrageiras mais tradicionalmente usadas na engorda de bovinos, em virtude do seu alto potencial de produção de matéria seca e da sua boa qualidade como alimento animal.

Recentemente a Empresa Brasileira de Pesquisa Agropecuária (EMBRAPA) vem desenvolvendo programas de seleção e avaliação de cultivares de Panicum maximum Jacq. Entre eles estão os cultivares Tanzânia-1 e Vencedor, que tem sido considerados muito promissores, porém, sobre os quais existe carência de informações quanto às exigências nutricionais.

O estudo dos nutrientes isoladamente e a interação entre eles pode não só esclarecer dúvidas sobre a nutrição e adubação da planta considerada, bem como pode resultar no melhor aproveitamento da espécie escolhida.

A escassez de resultados com cultivares lançados recentemente é um dos fatores que faz com que os produtores não conheçam muitas vezes as verdadeiras 
exigências destes capins, manejando-os de forma errada e muitas vezes não estimulando o potencial produtivo dessas forrageiras.

O suprimento de nitrogênio tem influência direta na produção de forragem devido ao maior perfilhamento e às maiores velocidade de elongação e taxa de aparecimento de folhas. $\mathrm{O}$ estudo do metabolismo do nitrogênio e de outros elementos que influenciem neste metabolismo constitui ferramenta importante para o aumento da produção de forragem.

$O$ interesse em estudar a importância dos nutrientes em gramíneas forrageiras e como estes nutrientes podem interferir na atividade de enzimas é ainda pequeno. A obtenção dessas novas informações deve contribuir para o conhecimento do processo de nutrição destas plantas.

Os objetivos deste estudo foram verificar as respostas de três cultivares de Panicum maximum Jacq a doses de nitrogênio e de magnésio, quanto à produção de matéria seca, à atividade enzimática, o perfilhamento e à composição mineral destas forrageiras. 


\section{REVISÃO DE LITERATURA}

\subsection{A espécie Panicum maximum}

O Panicum maximum Jacq. foi introduzido nas Américas provavelmente no fim do século XVIII, através dos navios que transportavam escravos, e daí se espalhou devido à sua alta produtividade, palatabilidade e boa persistência, segundo Jank (1994).

A espécie Panicum maximum Jacq, por ser preferencialmente apomítica, provoca o aparecimento de diversos cultivares, facilitando assim trabalhos de melhoramento genético.

O cultivar colonião, de acordo com Aronovich (1995), era o mais difundido no Brasil, sendo uma das gramíneas forrageiras que ocupavam maior área no país. Esse Panicum tem preferência por solos leves e de boa umidade, é exigente quanto à fertilidade do solo e apresenta boa resposta à adubação. Segundo Corrêa e Aronovich (1979) é resistente ao pisoteio e ao fogo. De acordo com levantamentos apresentados por Carriel et al. (1979), CONTIBRASIL (1985), Dias Filho (1987), Guss e Agostini (1984), Simão Neto et al. (1973) o capim colonião era a gramínea mais difundida nas regiões de São José do Rio Preto, Araçatuba e Presidente Prudente, no norte de São Paulo, no sul de Goiás, na Amazônia e no sul do Espírito Santo, respectivamente. 
Em 1982 foi assinado um convênio entre o ORSTOM Institute (Institute Français de Recherche Scientifique et Development en Coopération) e a EMBRAPA e as pesquisas com melhoramento de Panicum tomaram um impulso com a importação da coleção francesa, proporcionando meios para a realização de trabalhos de seleção no Centro Nacional de Pesquisa de Gado de Corte (CNPGC), em Campo Grande.

Em 1990 foi lançado aos produtores o cultivar Tanzânia-1 com algumas características superiores ao Colonião, como por exemplo, em produção de matéria seca total e foliar, maior ganho em peso diário por bovinos de corte e maior taxa de lotação das pastagens (Jank, 1994).

O cultivar Vencedor, que também estava presente na bateria de testes com o Tanzânia-1, apresentou características semelhantes ao Colonião, porém, foi lançado como sendo menos exigente em fertilidade do solo.

\subsection{Nitrogênio em gramíneas forrageiras.}

O nitrogênio é um macronutriente cuja importância tem sido realçada, tanto no uso de fertilizantes em nível mundial, como em conteúdo nas culturas e nas colheitas (Raij,1991).

O nitrato e o amônio são as formas de nitrogênio mais absorvidos pelas raízes das plantas superiores. Grande parte do amônio é incorporado em compostos orgânicos nas raízes, considerando que o nitrato é movél no xilema e pode também ser amarzenado nos vacúolos das células das raízes, colmos e orgãos de reserva (Marschner,1986).

Quanto ao mecanismo de absorção do nitrato, há evidências de que ele ocorre por processo ativo e sua absorção é regulada ou pela absorção de cátions $\left(\mathrm{K}^{+}, \mathrm{Mg}^{++}\right)$ou pela excreção de outros ânions $\left(\mathrm{OH}^{-}\right.$ou $\left.\mathrm{HCO}_{3}{ }^{-}\right)$, para manter a eletroneutralidade dentro da planta (Deane-Drummond, 1990). 
$\mathrm{Na}$ planta esse nutriente é inicialmente reduzido à forma amoniacal e combinado nas cadeias orgânicas, formando ácido glutâmico que, por sua vez, proporciona a formação de mais de uma centena de aminoácidos. Desses, cerca de vinte são usados na formação de proteínas, as quais participam como enzimas nos processos metabólicos das plantas, tendo assim uma expressão mais funcional do que estrutural. Além disso, o nitrogênio participa com quatro átomos na composição da molécula de clorofila (Mengel e Kirkby, 1987).

A adubação nitrogenada vem sendo muito estudada para as gramíneas. Werner et al. (1967), utilizando capim-colonião, verificaram que depois da adubação fosfatada, a nitrogenada foi a grande limitação para o desenvolvimento inicial dessa forrageira, atuando na produção de matéria seca e de perfilhamento.

Após a emergência, o crescimento de uma gramínea é continuado pelo desenvolvimento do sistema radicular e formação de novas folhas; posteriormente, verifica-se o perfilhamento e o alongamento do caule, o que resulta na formação de nós e entre-nós ( Gomide, 1989). Segundo Corsi (1984), a adubação nitrogenada favorece o número e o peso de perfilhos e estimula o alongamento do caule em capim-colonião ( Panicum maximum Jacq.), além de, conforme Monteiro e Werner (1977), aumentar a produção de matéria seca das pastagens.

As gramíneas tropicais podem responder a doses de nitrogênio de até 1800 $\mathrm{kg} \mathrm{ha}^{-1}$ ano $^{-1}$, segundo Chandler (1973), porém esta resposta ocorre de maneira diferente, conforme a espécie considerada.

Praticada com o objetivo de incrementar o rendimento forrageiro, a adubação nitrogenada tem reflexos também na qualidade da forragem produzida. Resultados de Gomide e Costa (1984) revelaram que enquanto os teores de nitrogênio e potássio mostraram associação linear positiva, os teores de fósforo mostraram associação linear negativa com incrementos de doses de 0 até $80 \mathrm{~kg}$ de $\mathrm{N} \mathrm{ha}^{-1}$ corte $^{-1}$. 
Monteiro et al. (1980), em um experimento realizado com adubação potássica aplicada ao capim colonião também adubado com doses de nitrogênio ( 0 a $225 \mathrm{~kg} \mathrm{de} \mathrm{N} \mathrm{ha}^{-1}$ ), constataram que houve aumento na produção de matéria seca, na proteína total anual e no teor de proteína no capim mediante o aumento da dose de adubo nitrogenado, independentemente da adubação potássica.

Segundo Quinn et al. (1961) a aplicação de $200 \mathrm{~kg} \mathrm{de} \mathrm{N} \mathrm{ha}^{-1} \mathrm{ano}^{-1}$ mais do que duplicou o rendimento dos pastos de capim-colonião formados há 11 anos, em relação a pastos que não foram adubados com nitrogênio. Além disso, os resultados demonstraram que a fertilização com fósforo e enxofre mas, sem nitrogênio, nesses pastos formados não apresentava vantagem econômica na produção de came.

Com relação a quilogramas de matéria seca produzida por quilogramas de nitrogênio aplicado, Crespo (1986) encontrou valores de 7,1 a 83,3 com capimcolonião, variando com a época do ano. Em outros estudos Alvim et al. (1990) encontraram valores para Brachiaria de 13,85, utilizando $150 \mathrm{~kg}$ de $\mathrm{N}^{-1}$.

Favoretto et al. (1988) avaliaram respostas de capim-colonião submetido a doses de nitrogênio de $0 ; 50$ e $100 \mathrm{~kg} \mathrm{ha}^{-1}$ e constataram aumento significativo na produção de matéria seca e nas taxas de crescimento que aumentaram de 47,39 para 68,16 e 83,71 $\mathrm{kg} \mathrm{ha}^{-1}$ dia $^{-1}$ respectivamente, em função das doses.

Trabalhando com capim-colonião irrigado e doses de nitrogênio de 0; 30; 60; 90; 120 e $150 \mathrm{~kg} \mathrm{ha}^{-1}$, Crespo (1986) verificou aumentos na taxa média de crescimento de 32 até $97 \mathrm{~kg}$ M.S. ha ${ }^{-1}$ dia $^{-1}$.

Santos et al.(1995) utilizando doses de nitrogênio em solução nutritiva com capim-Vencedor verificaram que tanto a produção de matéria seca como o perfilhamento foram influenciados significativamente pela adição de nitrogênio no meio de cultivo, tanto no primeiro quanto no segundo períodos de crescimento,

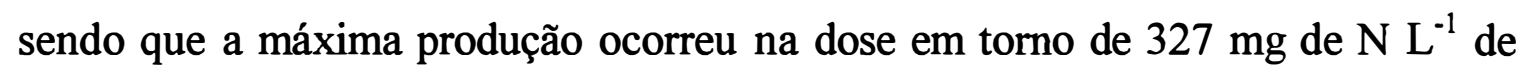
solução. 
É importante ressaltar que por ser o nitrogênio essencial na formação de proteínas, além da produção de matéria seca, o teor de proteína bruta torna-se um ótimo indicativo do suprimento de nitrogênio à forrageira. Com base nisso, Monteiro e Werner (1977) estudaram os efeitos de nitrogênio e fósforo no capimcolonião num experimento em vasos com um solo Latossolo Vermelho-Amarelo variação Laras, avaliando a produção de matéria seca e a quantidade total de proteína. Os resultados mostraram que no estabelecimento de uma pastagem o nitrogênio e o fósforo são muito importantes, elevando a produção de matéria seca de 1,3 g vaso $^{-1}$ na testemunha para 14,2 g vaso $^{-1}$ com aplicação de $\mathrm{N}$ e de $\mathrm{P}$, enquanto o teor de proteína total variou de 256 para $1263 \mathrm{mg} \mathrm{vaso}^{-1}$, com aqueles tratamentos.

Fernandes e Rossielo (1986) destacaram que o teor de N-total, que é geralmente determinado nas análises bromatológicas, não deve ser assumido como proteína verdadeira, porém dá idéia de melhorias no valor nutritivo do capim.

Com relação aos teores de nitrogênio encontrados nas plantas, Werner e Haag (1972), utilizando a técnica da omissão de nutrientes em solução nutritiva, encontraram 1,06 dag $\mathrm{N} \mathrm{kg}^{-1}$ na parte aérea coletada aos 33 dias, como nível adequado para a nutrição do capim-colonião. Esse valor está muito próximo daquele de 1,07 dag kg ${ }^{-1}$ anteriormente obtido por Werner et al.(1967) para esta forrageira em solo da Noroeste do Estado de São Paulo, no tratamento completo, também aos 33 dias. Ferrari Neto (1991) encontrou um valor superior a esses, da ordem de 1,8 dag kg-1 aos 40 dias, em um experimento em vasos com um solo Latossolo Vermelho-Escuro.

Dentre os fatores que governam a aquisição de nitrogênio pelas plantas e sua resposta em crescimento, destaca-se a proporção de amônio e do nitrato no meio de cultivo (Mills et al.,1976). A acumulação do nitrato no vacúolo é importante para o balanço de cátions e ânions e para osmorregulação. Entretanto, 
para ser incorporado em estruturas orgânicas e desempenhar funções essenciais nas plantas, o nitrato tem que ser reduzido à amônia (Marschner,1986).

Silveira e Sant'anna (1988) conduziram um experimento para estudar os efeitos do nitrato e do amônio no crescimento e nas frações de nitrogênio em capim-colonião. Concluíram que a produção de matéria seca e o teor de nitrogênio total decresceram com o aumento da concentração de amônio na solução nutritiva. A ocorrência de um distúrbio no metabolismo protéico foi obtido a partir da utilização de $50 \%$ de amônio, sendo que a maior absorção do nitrato por essa forrageira ocorreu na proporção de 75\%:25\% entre nitrato e amônio.

Abreu (1994) observou que todo o suprimento de nitrogênio como nitrato provocou maiores produção de matéria seca e perfilhamento do capim-Tanzânia-1 do que quando o amônio perfazia $25 \%$ ou mais do total em solução onde crescia o capim-Tanzânia.

Em experimento comparando duas fontes de adubos nitrogenados (nitrato de amônio e uréia ) e três níveis de $\mathrm{N}\left(0,150\right.$ e $\left.300 \mathrm{~kg} \mathrm{ha}^{-1} \mathrm{ano}^{-1}\right)$ na fertilização de Panicum maximum Jacq., em um solo ligeiramente ácido, Pacheco et al.(1984 ) mostraram que não houve diferença significativa entre as fontes de nitrogênio e que a maior dose empregada foi a que resultou na maior produção de matéria seca do capim naquele solo.

O nitrogênio possui efeitos no desenvolvimento fisiológico da forragem (Corsi,1975). Ele provoca aumento na longevidade das folhas, como demonstraram Corsi et al.(1994) trabalhando com as braquiárias Marandu, decumbens e humidícola e concluindo que a adição de nitrogênio evidenciou maior taxa de elongação, além de maior número de folhas em elongação para o Marandu. 


\subsection{Magnésio em gramíneas forrageiras}

O magnésio é um macronutriente que na maioria das vezes é suprido pelo corretivo de acidez do solo, juntamente com o cálcio. As exigências das culturas são da ordem de 10 a $40 \mathrm{~kg} \mathrm{ha}^{-1}$ e bem abaixo de nutrientes como nitrogênio e potássio (Raij, 1991).

Segundo Marschner (1986 ), o magnésio é extremamente importante para as plantas, pois além de ser o átomo central da molécula de clorofila, ele funciona como um elemento construtor para a agregação de subunidades de ribossomos, processo necessário para a síntese de proteína. Quando há deficiência de magnésio essas subunidades se dissociam e a síntese de proteínas cessa, afetando o tamanho, a estrutura e a função dos cloroplastos, já que $25 \%$ do total de proteína está neles localizado. Essa deficiência faz aumentar o teor de N-nãoprotéico e diminuir o teor de N-protéico nas plantas. Além dessas funções, há uma longa lista de reações enzimáticas que requerem ou são promovidas pelo $\mathrm{Mg}^{2+}$, e entre elas está a atividade da glutamina sintetase, que regula a assimilação da amônia nos cloroplastos.

O magnésio é, segundo Zimmerman (1947), abundante em tecidos meristemáticos jovens, nas sementes e nos frutos podendo estar presente em três estados: em formas combinadas no protoplasma, na molécula de clorofila e na forma de sais inorgânicos.

Marschner (1986) relatou que folhas deficientes em magnésio apresentam acúmulo de amido, o que é o principal responsável pelo alto conteúdo de matéria seca dessas folhas, indicando que a fotossíntese por si mesma é menos prejudicada do que a degradação do amido nos cloroplastos e o transporte de açúcar dentro das células. Todos estes processos metábolicos requerem alta energia e, portanto, $\mathrm{o} \mathrm{Mg}^{2+}$ para a transferência dessa energia. 
Cultivando o capim-colonião num Latossolo do Estado de Minas Gerais, Marun (1990) realizou calagem de modo que o cálcio trocável variasse de 2,4 a $3,7 \mathrm{cmol}_{\mathrm{c}} \mathrm{kg}^{-1}$ e o magnésio trocável de 1,7 a $0,2 \mathrm{cmol}_{\mathrm{c} \mathrm{kg}} \mathrm{kg}^{-1}$, e a relação Ca:Mg no solo fosse de 1,$4 ; 4,0 ; 9,0$ e 18,0. Quando esta relação excedia ao valor 4,0 observou decréscimos na produção de matéria seca desse capim, devido provavelmente aos baixos teores de magnésio no solo.

Gomide et al. (1986) testaram calagem e níveis de fósforo no estabelecimento e produção do capim-colonião no cerrado e verificaram interações entre calagem e uso de fosfato de rocha e aumentos no teor de magnésio de $0,16 \mathrm{dag} \mathrm{kg}^{-1}$ para $0,20 \mathrm{dag} \mathrm{kg}^{-1}$.

Premazzi (1991) conduziu um experimento num solo Latossolo VermelhoAmarelo ácido com elevação da saturação por bases do solo e obteve teores de $\mathrm{Mg}$ para o capim-colonião de 0,$67 ; 0,57 ; 1,07 \mathrm{dag} \mathrm{kg}^{-1}$ no primeiro corte, respectivamente quando a calagem objetivou aumentar a saturação por bases do solo 30,50 e $70 \%$.

A carência de resultados envolvendo magnésio na adubação, não somente de Panicum maximum Jacq mas das forrageiras em geral, é um fato marcante na literatura. Alguns resultados com leguminosas forrageiras estão disponíveis.

Em um experimento utilizando os solos Podzólico Vermelho Amarelo e Latossolo Vermelho-Amarelo, Colozza et al. (1983) cultivaram a soja-perene Tinaroo sob diversas combinações de cálcio, magnésio e enxofre. Paralelamente estudaram os efeitos da aplicação de magnésio (como $\mathrm{MgO}$ ) de $0 ; 54$ e $108 \mathrm{~kg}$ de $\mathrm{Mg} \mathrm{ha}^{-1}$ no solo Podzólico e de 0; 170 e $340 \mathrm{~kg}$ de $\mathrm{Mg} \mathrm{ha}^{-1}$ no Latossolo, sem adição de qualquer corretivo de acidez do solo. Essas aplicações provocaram aumentos significativos e, na maior parte dos casos, lineares na produção de matéria seca e na quantidade de nitrogênio total dessa leguminosa, em ambos os solos. 
Monteiro (1993), trabalhando com níveis de magnésio em soja-perene Tinaroo, obteve como níveis críticos deste elemento para essa leguminosa valores entre 0,28 e $0,48 \mathrm{dag} \mathrm{kg}^{-1}$ na parte aérea toda, entre 0,31 e $0,39 \mathrm{dag} \mathrm{kg}^{-1}$ nos ápices da planta e entre 0,27 e $0,47 \mathrm{dag} \mathrm{kg}^{-1}$ nas folhas novas.

\subsection{Atividade da redutase do nitrato}

Sendo o nitrato a principal forma de nitrogênio disponível em solos oxidados e também a absorvida pelas plantas, ele sofre algumas transformações para ser aproveitado pelo vegetal. A primeira reação é catalisada pela redutase do nitrato, que é amplamente distribuída nas plantas, e muito importante no processo de formação de proteínas (Lehninger,1976). A importância da redução e assimilação do nitrato para a vida das plantas é semelhante à redução e assimilação do $\mathrm{CO}_{2}$ na fotossíntese (Marschner, 1986).

O íon nitrato, após ser absorvido pela planta, pode ser estocado nos vacúolos do sistema radicular (Taiz e Zieger, 1991) ou ser translocado via xilema para a parte aérea, onde pode ser armazenado ou reduzido (Rufty et al.,1986).

A atividade da redutase do nitrato em plantas é uma boa estimativa do estado nutricional da planta quanto ao nitrogênio e tem boa correlação com crescimento e produção, porém esta atividade é influenciada por muitos fatores ( Srivastava, 1980). A atividade dessa enzima tem grande dependência de fluxos contínuos do nitrato para que se mantenha viva, conforme demonstraram Bendix et al. (1982), em trabalho realizado com Paspalum notatum Flugge, onde foi observado aumento da atividade da redutase do nitrato com o parcelamento em três aplicações de $30 \mathrm{mg}$ de $\mathrm{N} \mathrm{kg}^{-1}$ de solo, em relação à única adubação com 90 mg de $\mathrm{N} \mathrm{kg}^{-1}$ de solo. 
Fernandes e Freire (1978), em experimento com Brachiaria sp., relataram que a atividade da redutase do nitrato foi positivamente correlacionada $(r=0,97)$ com o teor de nitrogênio proteico das folhas e bainhas.

Beevers e Hageman (1969) afirmaram que a atividade da redutase do nitrato pode ser induzida pela temperatura, intensidade luminosa e suprimento do nitrato, enquanto Yoneyama et al. ( 1987) relatou que o nível de irradiância afeta a expressão desta enzima. Além disto, Campbell (1988) destacou que esta enzima é uma das duas que requer molibdênio para sua atividade nas plantas.

Bowerman e Goodman (1971), em experimentos com perfilhos de Lolium perene L. cultivados em solo, variaram a intensidade de luz em $1 ; 3 ; 9 ; 16 ; 45$ e $93 \mathrm{~W} \mathrm{~m}^{-2}$ e os resultados mostraram claramente que a atividade da redutase do nitrato teve seu máximo entre 45 e $93 \mathrm{~W} \mathrm{~m}^{-2}$.

Em experimentos com cevada (Hordeum vulgare L. cv. Mazurka), Lewis et al. (1982) obtiveram aumento na atividade da redutase do nitrato de 1,3 vezes após 3 horas de luz quando comparada com o período escuro, sendo que após 8 horas de iluminação esses valores chegaram ao máximo de 1,7 vezes maior.

Ohta et al. (1988) conduziram um experimento e comprovaram que a aplicação de sódio incrementou signficativamente o crescimento e colaborou nos acréscimos da atividade da redutase do nitrato em algumas plantas $\mathrm{C} 4$, entre elas estando o Panicum maximum Jacq.

Utilizando a colza (Brassica napus L.) como planta teste, Shen et al. (1993) observaram que a atividade da redutase do nitrato foi incrementada com o acréscimo de nitrogênio no solo e que este efeito foi maior na presença do que na ausência de boro.

Huber e Huber (1995), em experimentos com folhas de espinafre (Spinacia oleracea L.), observaram que a atividade da redutase do nitrato foi menor e mais fortemente inibida pela presença do íon magnésio quando as folhas foram cortadas no escuro comparado com o corte à luz. 
Determinando a atividade da redutase do nitrato em alguns genótipos de milho (Zea mays L.) cultivados sob duas doses de nitrogênio (20 e $60 \mathrm{~kg} \mathrm{ha}^{-1}$ ) Purcino et al. (1994a) concluíram que no período de amostragem (3 dias antes e 20 e 42 dias após o embonecamento) não houve correlação entre a atividade desta enzima e os níveis de nitrogênio e a produtividade do milho, porém observaram que havia variabilidade nos valores de atividade da redutase nos três estádios onde a planta foi amostrada.

A determinação da atividade da redutase do nitrato tem apresentado boas correlações com teores de nitrogênio total nas plantas e nos grãos em trigo (Triticum aestivum L.) (Eilrich e Hageman, 1973), produção de grãos e teor proteico destes grãos em milho (Deckard et al., 1973) e no total de matéria seca acumulada em Lolium perene L.(Bowerman e Goodman, 1971).

Fernandes e Freire (1976), em experimentos com Brachiaria sp concluíram que o nível basal (medida no fim de um fotoperíodo) de atividade da redutase do nitrato pode ser usado para indicar "status" do $\mathrm{N}$ na planta quando se deseja eliminar a interferência de fatores ambientais como luz e temperatura.

Utilizando dezessete cultivares de sorgo (Sorghum sudanense Stapf), Eck e Hageman (1974) determinaram a atividade da redutase do nitrato e constataram que existem diferenças significativas entre os cultivares e que a atividade desta enzima decresce com a idade da planta.

Andrade (1994) em trabalho com capim-colonião e proporções de $\mathrm{NH}_{4}{ }^{+}: \mathrm{NO}_{3}{ }^{-}$detectou que a atividade in vitro da redutase do nitrato aumentou significativamente quando foram fornecidas ambas as fontes de nitrogênio, indicando certa ação estimulatória do íon amônio na atividade da enzima. 


\subsection{Atividade da glutamina sintetase}

A enzima glutamina sintetase (GS) requer glutamato,amônia e ATP para sua atividade. Está localizada nos cloroplastos e no citoplasma das folhas e no citoplasma das raízes (Oaks e Hirel, 1985) e é considerada como a principal rota de assimilação de amônia em plantas (Miflin e Lea, 1980; McNally et al., 1983).

A glutamina sintetase pode apresentar várias isoformas, já identificadas por cromatografia de troca iônica, ponto isoelétrico ou propriedades imunológicas (Layzell,1990). As folhas das plantas, em geral, contém duas formas de GS, uma citossólica $\left(G_{1}\right)$ e uma cloroplastídica $\left(G_{2}\right)$, porém a $G_{1}$ é a forma predominante em plantas $\mathrm{C}_{4}$ (Vange e Griffth,1990).

O'neal e Joy (1974) estudaram a atividade da glutamina sintetase em ervilhas e comprovaram que esta é afetada por cátions divalentes e que a presença do $\mathrm{Mg}^{2+}$ resulta num expressivo aumento da atividade dessa enzima.

Andrade (1994) trabalhando com capim-colonião e proporções de $\mathrm{NH}_{4}^{+}: \mathrm{NO}_{3}{ }^{-}$constatou que a atividade da glutamina sintetase aumentou no sistema radicular a partir da proporção 25/75. Aumentos na atividade da GS foram detectados, em função do incremento $\mathrm{de} \mathrm{NH}_{4}{ }^{+}$em raízes de milho (Anghinoni et al., 1988), raízes e folhas de cevada (Lewis et al., 1982) e cultura de células em raízes de Ipomoea (Zink, 1989).

Utilizando duas linhagens de milho e dois cultivares de sorgo, Purcino et al. (1994b) realizaram um experimento fornecendo dois níveis do nitrato às plantas e avaliaram a atividade da glutamina sintetase. Concluíram que a atividade da GS não foi um critério adequado para separar os materiais eficientes na utilização de nitrogênio no nível mais baixo do nitrato, enquanto que no nível mais alto esta separação pode ser feita.

Pouco se sabe sobre o sistema de regulação da atividade desta enzima. A atividade da glutamina sintetase aumenta expressivamente durante o 
desenvolvimento do nódulo em raízes de leguminosas, em folhas estioladas expostas à luz e em folhas e raízes de plantas crescendo em nitrato. Lara et al. (1983) e Cullimore e Bennet (1988) atribuíram as alterações na atividade da GS, durante o desenvolvimento dos órgãos, a uma expressão diferencial das izoenzimas. 


\section{MATERIAL E MÉTODOS}

O experimento foi realizado na casa-de-vegetação localizada no Setor de Nutrição Mineral de Plantas, Departamento de Química, da Escola Superior de Agricultura "Luiz de Queiroz"-USP, com início em dezembro de 1995 e se estendendo até fevereiro de 1996. Foram utilizados os cultivares Colonião, Tanzânia-1 e Vencedor da espécie Panicum maximum Jacq..

\subsection{Condições de instalação e condução do experimento}

As sementes das gramíneas foram colocadas para germinar em recipientes de alumínio contendo areia lavada. Vasos plásticos com volume de 3,6 L foram preenchidos com sílica e receberam quinze mudas das plantas quando elas tinham cerca de 3 centímetros de altura, sendo cada bloco transplantado em um dia.

Procedeu-se a desbastes periódicos para que cada vaso permanecesse no final com cinco plantas. Os vasos receberam a solução nutritiva correspondente a cada tratamento, a qual foi mantida nos vasos durante o dia e drenada à noite. A solução foi circulada através da sílica duas vezes por dia e trocada a cada quinze dias. 


\subsection{Tratamentos, soluções nutritivas e delineamento experimental}

Foram utilizada três doses de nitrogênio ( 42,210 e $378 \mathrm{mg}$ de $\left.\mathrm{N} \mathrm{L}^{-1}\right)$ e duas doses de magnésio ( 4,8 e $48 \mathrm{mg}$ de $\mathrm{Mg} \mathrm{L}^{-1}$ ). As soluções foram preparadas a partir daquela proposta por Sarruge (1975), devidamente modificada para satisfazer o suprimento de nitrogênio e de magnésio. A forma como foi preparada a solução de cada tratamento é mostrada na tabela 1 .

Empregou-se um esquema fatorial 3x2x3 (3 doses de $\mathrm{N}, 2$ doses de $\mathrm{Mg}$ e 3 cultivares) perfazendo um total de 18 tratamentos que foram distribuídas segundo o delineamento experimental de blocos ao acaso, com quatro repetições.

\subsection{Coleta do material vegetal}

Aos 35 dias após o transplante foi realizado o primeiro corte e as plantas foram separadas em lâminas novas (lâminas das duas folhas superiores totalmente expandidas mais a folha em expansão), lâminas velhas (lâminas das demais folhas) e colmos+bainhas (colmo propriamente dito mais as bainhas que foram mantidas a eles circundadas). As folhas foram consideradas totalmente expandidas quando apresentavam a lígula visível. Aos 33 dias após o primeiro corte realizou-se o segundo corte e as plantas foram separadas segundo o mesmo critério, sendo que as raízes também foram separadas e lavadas. $O$ material vegetal foi colocado para secar em estufa de circulação forçada de ar à temperatura de $65^{\circ} \mathrm{C}$, até massa constante. 
Tabela 1. Volumes das soluções estoque empregados no preparo das soluções nutritivas para as doses de nitrogênio e magnésio estudadas.

\begin{tabular}{|c|c|c|c|c|c|c|c|}
\hline \multirow[b]{2}{*}{$\begin{array}{l}\text { Soluções } \\
\text { estoque }\end{array}$} & \multirow[b]{2}{*}{ Concentração } & \multicolumn{6}{|c|}{ Volumes $\left(\mathrm{mL} \mathrm{L}^{-1}\right)$} \\
\hline & & $\begin{array}{l}42 \mathrm{~N} \mathrm{e} \\
4,8 \mathrm{Mg}\end{array}$ & $\begin{array}{l}42 \mathrm{~N} \mathrm{e} \\
48 \mathrm{Mg}\end{array}$ & $\begin{array}{l}210 \mathrm{~N} \mathrm{e} \\
4,8 \mathrm{Mg}\end{array}$ & $\begin{array}{l}210 \mathrm{~N} \mathrm{e} \\
48 \mathrm{Mg}\end{array}$ & $\begin{array}{l}378 \mathrm{~N} \mathrm{e} \\
4,8 \mathrm{Mg}\end{array}$ & $\begin{array}{l}378 \mathrm{~N} \mathrm{e} \\
48 \mathrm{Mg}\end{array}$ \\
\hline $\mathrm{KH}_{2} \mathrm{PO}_{4}$ & $\mathrm{M}$ & 1 & 1 & 1 & 1 & 1 & 1 \\
\hline $\mathrm{KNO}_{3}$ & $\mathrm{M}$ & 3 & 1,4 & 5 & 1,4 & 5 & 5 \\
\hline $\mathrm{K}_{2} \mathrm{SO}_{4}$ & $0,5 \mathrm{M}$ & - & 2 & - & - & - & - \\
\hline $\mathrm{Ca}\left(\mathrm{NO}_{3}\right)_{2}$ & $\mathrm{M}$ & - & - & 5 & 5 & 5 & 5 \\
\hline $\mathrm{MgSO}_{4}$ & $\mathrm{M}$ & 2 & 0,2 & 2 & 0,2 & 2 & 0,2 \\
\hline $\mathrm{KCl}$ & M & 2 & 1,6 & - & 3,6 & - & - \\
\hline $\mathrm{CaCl}_{2}$ & $\mathrm{M}$ & 5 & 5 & - & - & - & - \\
\hline $\mathrm{NH}_{4} \mathrm{NO}_{3}$ & $\mathrm{M}$ & - & - & - & - & 6 & 5,2 \\
\hline$\left(\mathrm{NH}_{4}\right)_{2} \mathrm{SO}_{4}$ & $\mathbf{M}$ & - & 0,8 & - & 1,8 & - & 0,8 \\
\hline Micro - Fe & * & 1 & 1 & 1 & 1 & 1 & 1 \\
\hline Fe-EDTA & ** & 1 & 1 & 1 & 1 & 1 & 1 \\
\hline
\end{tabular}

* A solução de micronutrientes teve a seguinte composição $\left(\mathrm{g} \mathrm{L} \mathrm{L}^{-1}\right): \mathrm{H}_{3} \mathrm{BO}_{3}-2,86$; $\mathrm{MnCl}_{2} \cdot 4 \mathrm{H}_{2} \mathrm{O}-1,81 ; \mathrm{ZnCl}_{2}-0,10 ; \mathrm{CuCl}_{2}-0,04$ e $\mathrm{H}_{2} \mathrm{MoO}_{4} \cdot \mathrm{H}_{2} \mathrm{O}-0,02$.

** Dissolveram-se 26,1g de EDTA dissódico em $286 \mathrm{ml}$ de $\mathrm{NaOH} \mathrm{N}$, misturando-se com 24,0 g de $\mathrm{FeSO}_{4} \cdot 7 \mathrm{H}_{2} \mathrm{O}$, arejando-se por uma noite e completando-se a $1 \mathrm{~L}$ de água deionizada. 


\subsection{Determinações no material vegetal}

\section{-Produção de matéria seca}

Foi determinada a produção de matéria seca de cada componente da parte aérea e das raízes como um todo, após a secagem em estufa.

\section{- Composição mineral}

A determinação das concentrações de nitrogênio, fósforo, potássio, cálcio, magnésio, enxofre, cobre, ferro, manganês e zinco em cada fração da parte aérea e nas raízes foi efetuada conforme metodologia de Sarruge e Haag (1974).

A digestão utilizada para a determinação do nitrogênio foi a sulfúrica e o método analítico foi o micro-Kjeldahl, para os demais nutrientes a digestão nítrico perclórica foi empregada e os métodos analíticos foram: fósforo por colorimetria do metavanadato; potássio por fotometria de chama; enxofre por turbidimetria do sulfato de bário e os demais nutrientes- espectrofotometria de absorção atômica.

\section{- Atividade da redutase do nitrato}

A determinação da atividade da redutase do nitrato foi conduzida tomando-se o limbo foliar da segunda folha completamente expandida de cada planta aos 27 dias no primeiro crescimento e 26 dias no segundo crescimento das plantas. As plantas eram submetidas a 2 horas de exposição à luz, dentro de uma câmara-de-crescimento, antes de serem coletadas as folhas. 
O método utilizado para a determinação foi o de Mulder et al. (1959). A determinação começou com a incubação, por duas horas, de $200 \mathrm{mg}$ de material verde cortado, em meio de $\mathrm{KNO}_{3}$ em tampão fosfato. Foi retirado $1,0 \mathrm{~mL}$ do meio de incubação e o $\mathrm{NO}_{2}$ presente foi determinado por adição de $1,0 \mathrm{~mL}$ de ácido sulfanílico e $\mathrm{HCl}$ à $20 \%$ para paralizar a reação, seguido da adição de $1,0 \mathrm{~mL}$ de alfa-naftilamina, para desenvolver a cor ao reagir com o $\mathrm{NO}_{2}$. A leitura foi realizada em colorímetro a $540 \mathrm{~nm}$, utilizando-se reta padrão de nitrito para cálculo da concentração de $\mathrm{NO}_{2}$ no meio.

\section{- Atividade da glutamina sintetase}

A atividade específica da glutamina sintetase foi procedida tomando-se amostras das lâminas foliares aos 35 dias no primeiro crescimento e 33 dias no segundo.

O método utilizado para esta determinação foi o de Elliott (1953), com modificações. Foi utilizado $0,5 \mathrm{~g}$ de material verde que foi macerado com a ajuda do tampão e levado à centrífuga. A reação foi conduzida sob agitação contínua em banho maria à $30^{\circ} \mathrm{C}$ e continha $0,5 \mathrm{~mL}$ de tampão TRIS-HCl $200 \mathrm{mM}, \mathrm{pH}$ 7,5; 0,2 mL de ATP $50 \mathrm{mM}, \mathrm{pH}$ 7,0; 0,5 mL de glutamato de sódio $500 \mathrm{mM} ; 0,1$ $\mathrm{ml}$ de $\mathrm{MgSO}_{4} \mathrm{M} ; 0,1 \mathrm{~mL}$ de cisteína $100 \mathrm{mM} ; 0,3 \mathrm{~mL}$ de hidroxilamina $100 \mathrm{mM}$, $\mathrm{pH}$ 7,0; 0,3 mL de extrato; totalizando um volume de $2 \mathrm{~mL}$.

A reação foi interrompida pela adição de $2 \mathrm{~mL}$ do reagente contendo $\mathrm{FeCl}_{3}(10 \%), \mathrm{TCA}(24 \%), \mathrm{HCl}(\mathrm{N})$ na proporção de 1:1:1. Em seguida a mistura foi centrifugada a 3000 rotações $\min ^{-1}$ e no sobrenadante foi realizada a leitura em colorímetro para detectar a formação de y-glutamil hidroximato. Essa leitura foi cumprida a $540 \mathrm{~nm}$ em espectofotômetro, utilizando-se uma curva padrão previamente preparada. 


\subsection{Análises estatísticas}

Os resultados foram submetidos à análise de variância e no caso do teste $\mathrm{F}$ significativo, foram feitos os devidos desdobramentos para interações triplas e duplas.

Foram feitos a análise de regressão para as doses de nitrogênio e teste de comparação de médias (Tukey a 5\%) para os cultivares e as doses de magnésio, utilizando o programa estatístico SAS-WINDOWS (1995). 


\section{RESULTADOS E DISCUSSÃO}

\subsection{Produção de matéria seca da parte aérea}

A análise de variância da produção de matéria seca da parte aérea mostrou significância para a interação tripla entre os cultivares, as doses de nitrogênio e as doses de magnésio, tanto para o primeiro como para o segundo corte.

No primeiro corte, o cultivar Colonião respondeu as doses de nitrogênio, segundo modelo quadrático quando a dose de magnésio era de $4,8 \mathrm{mg} \mathrm{L}^{-1}$ de solução e de forma linear quando a dose era de $48 \mathrm{mg} \mathrm{L}^{-1}$ de solução. $\mathrm{O}$ cultivar Tanzânia-1 demonstrou comportamento similar ao Colonião enquanto que o cultivar Vencedor mostrou resposta linear na condição de baixo suprimento de magnésio $\left(4,8 \mathrm{mg} \mathrm{L}^{-1}\right)$ e resposta segundo modelo quadrático na dose mais alta $\left(48 \mathrm{mg} \mathrm{L}^{-1}\right)$, como se nota na Figura 1 .

No segundo corte, as equações demonstraram ajustes ao modelo quadrático para a produção de matéria seca da parte aérea dos cultivares Colonião e Vencedor, em função das doses de nitrogênio nas duas doses de magnésio. Para o cultivar Tanzânia-1 o aumento na produção de matéria seca da parte aérea seguiu uma equação de segundo grau, para as doses de nitrogênio, quando a dose de magnésio foi de $4,8 \mathrm{mg} \mathrm{L}^{-1}$ de solução e uma função de primeiro grau, quando o magnésio estava na dose de $48 \mathrm{mg} \mathrm{L}^{-1}$ de solução ( Figura 2).

A produção de matéria seca da parte aérea dos três cultivares de Panicum estudados sofreu incrementos em função do nitrogênio fornecido, o que concorda com Gomide ( 1989 ) e Corsi (1984). 


\section{COLONIÃO}
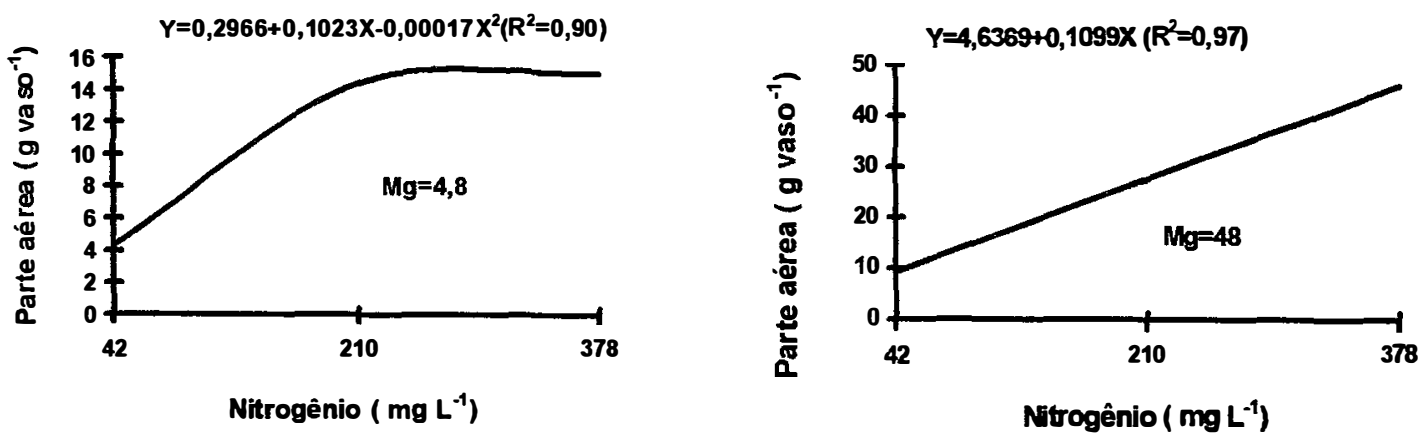

\section{TANZÂNIA-1}
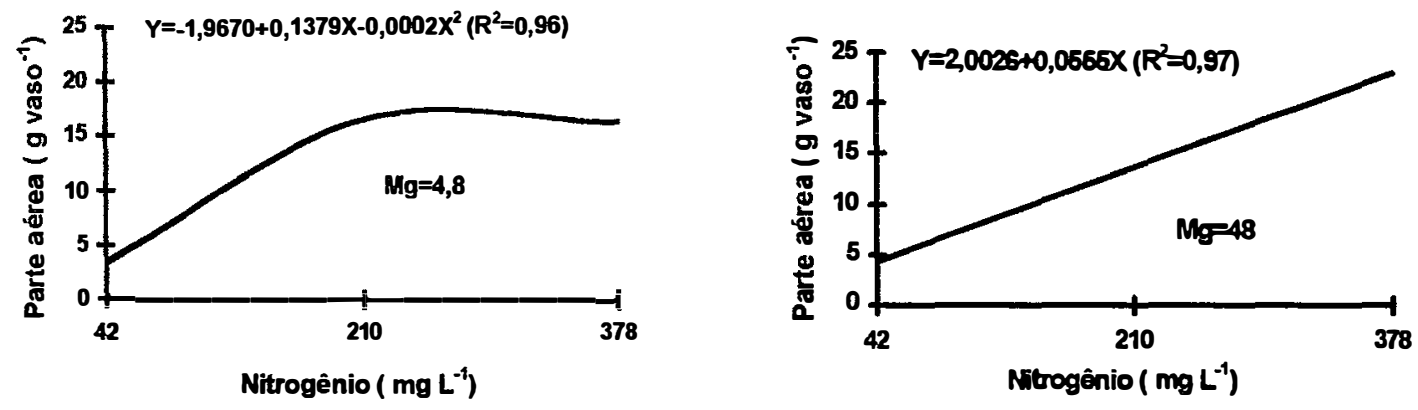

\section{VENCEDOR}
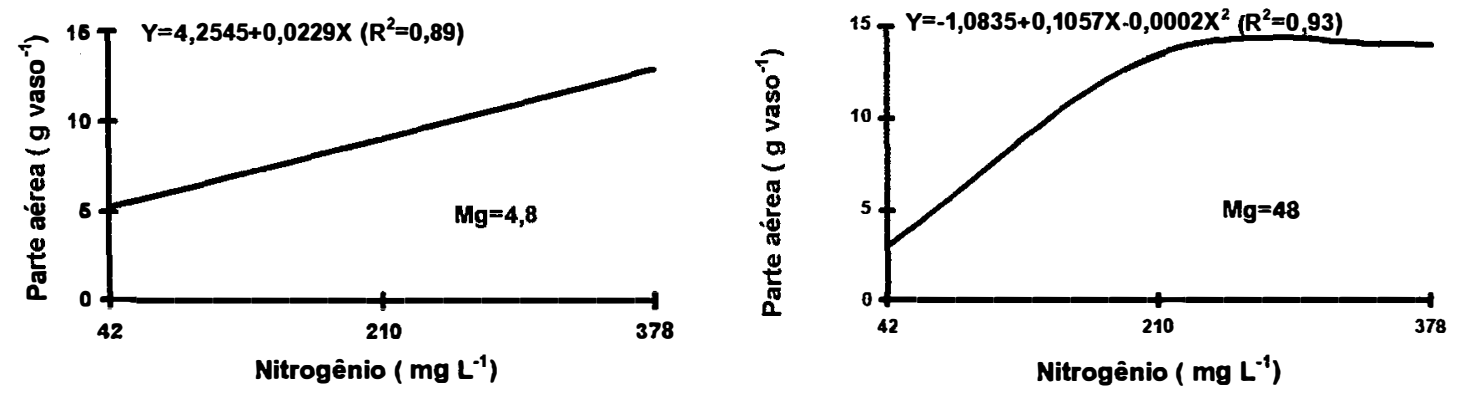

Figura 1. Produção da matéria seca da parte aérea, no primeiro período, dos cultivares Colonião, Tanzânia-1 e Vencedor de Panicum maximum Jacq, em função das doses de nitrogênio e de magnésio. 


\section{COLONIÃO}
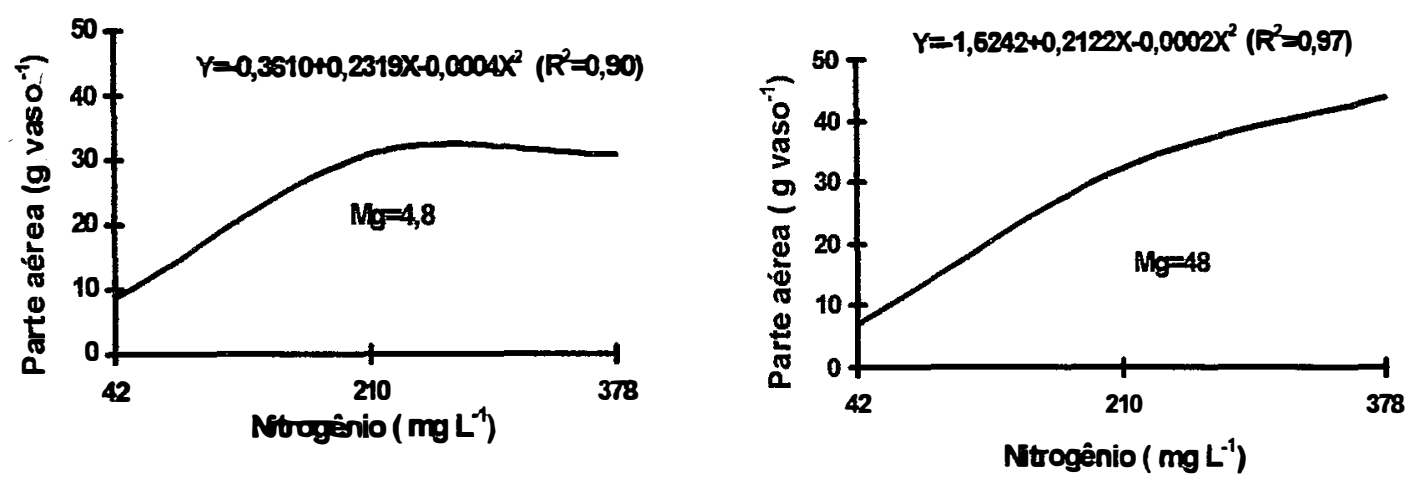

TANZÂNIA-1
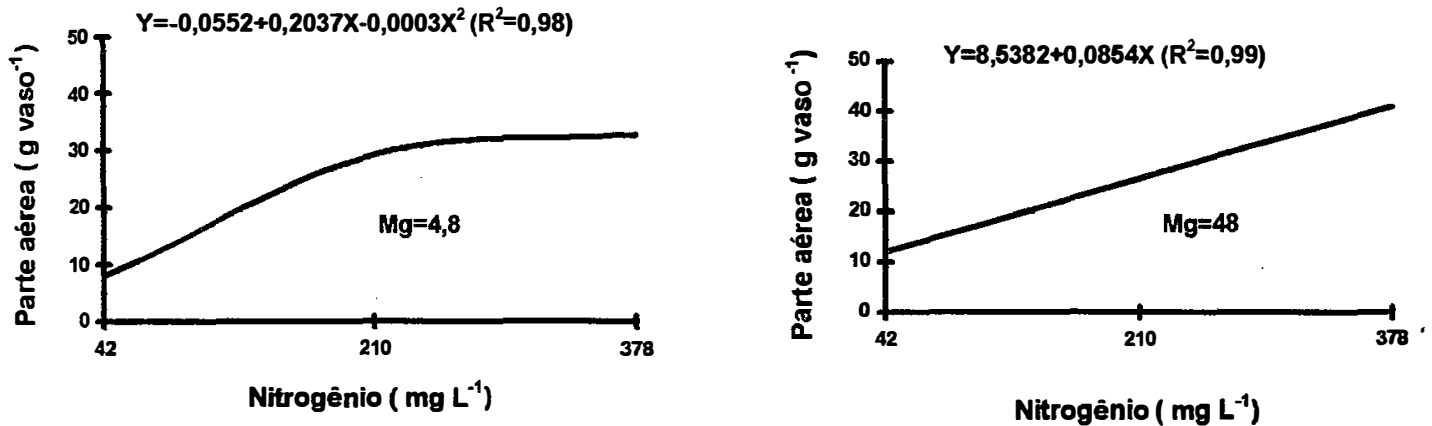

VENCEDOR
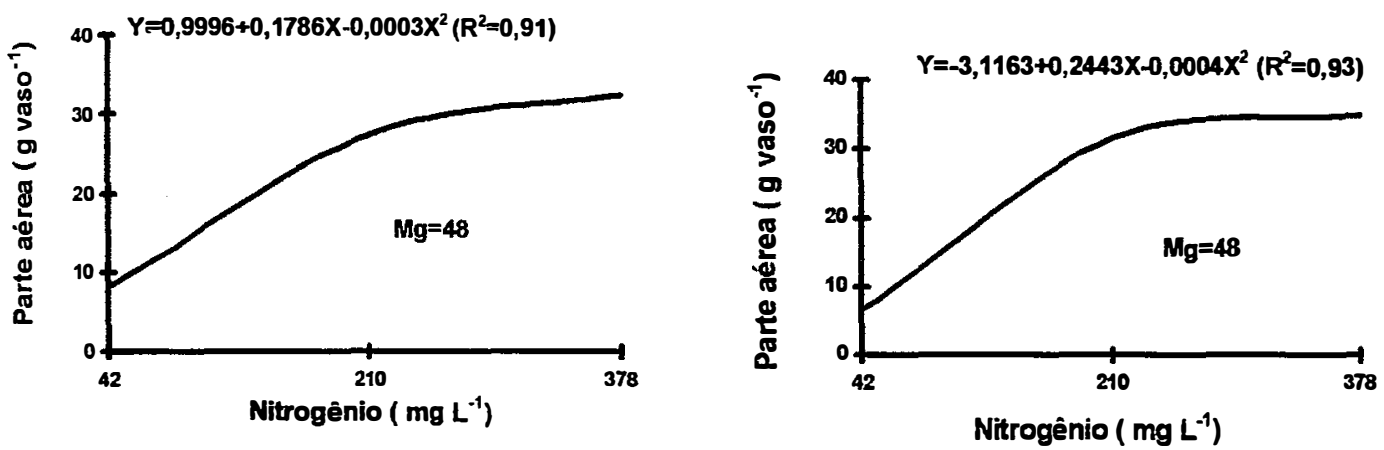

Figura 2. Produção da matéria seca da parte aérea, dos cultivares Colonião, Tanzânia-1 e Vencedor de Panicum maximum Jacq, no segundo corte em função das doses de nitrogênio e de magnésio. 
Ainda na Figura 2 pode-se notar que a máxima produção da parte aérea ocorreu sempre em uma concentração de nitrogênio mais elevada quando o magnésio estava em $48 \mathrm{mg} \mathrm{L}^{-1}$ do que quando o magnésio era fornecido como 4,8 $\mathrm{mg} \mathrm{L}^{-1}$, sendo os pontos de máxima produção nas seguintes concentrações de nitrogênio; no Colonião ( 290 e 530) e no Vencedor ( 298 e 305) nas duas doses de magnésio empregadas. Para o cultivar Colonião a produção de matéria seca na dose de nitrogênio de $42 \mathrm{mg} \mathrm{L}^{-1}$ é $29 \%$ daquela estimada com a dose máxima de nitrogênio, encontrada derivando-se as equações do $2^{\circ}$ grau .

A importância do nitrogênio na produção de matéria seca foi demonstrada através do incremento nos três cultivares utilizados, sendo que o aumento linear, em algumas curvas demonstra o potencial da forrageira em responder a níveis mais elevados, nas mesmas condições do experimento.

Considerando os cultivares estudados, dentro das doses de nitrogênio e magnésio, nota-se que na dose de $42 \mathrm{mg} \mathrm{L}^{-1}$ de solução de nitrogênio não houve diferença significativa entre os cultivares, em qualquer das doses de magnésio, no primeiro crescimento ( Tabela 2). Quando a dose de nitrogênio foi de $210 \mathrm{mg} \mathrm{L}^{-1}$, na dose de magnésio de $4,8 \mathrm{mg} \mathrm{L}^{-1}$, o cultivar Colonião apresentou produção de matéria seca estatisticamente superior ao Vencedor, sendo que na dose de magnésio de $48 \mathrm{mg} \mathrm{L}^{-1}$ não houve diferença significativa entre os cultivares. $\mathrm{Na}$ mais alta dose estudada de nitrogênio ( $378 \mathrm{mg} \mathrm{L}^{-1}$ ), o comportamento dos cultivares foi o mesmo tanto no nível de magnésio de 4,8 como na dose de $48 \mathrm{mg}$ $\mathrm{L}^{-1}$, ocorrendo um menor rendimento de matéria seca do cultivar Vencedor com relação ao Tanzânia-1, e sendo ambos semelhantes ao Colonião.

Quando a dose de nitrogênio é baixa, situação bastante frequente na pecuária extensiva, os três cultivares se comportaram de maneira igual, porém quando este elemento esteve presente em maiores doses, houve diferenças.

No segundo crescimento, na dose de magnésio de $4,8 \mathrm{mg} \mathrm{L}^{-1}$ não houve diferença na produção de matéria seca entre os cultivares, em qualquer dose de 
nitrogênio utilizada (Tabela 3). Quando a dose de magnésio foi elevada para 48 $\mathrm{mg} \mathrm{L}^{-1}$ os cultivares mostraram diferenças, em todas as doses de nitrogênio utilizadas. Isto demonstra as diferentes respostas dos cultivares de uma mesma espécie quando os nutrientes são fornecidos em doses maiores.

A produção de matéria seca da parte aérea dos cultivares Colonião e Tạnzânia-1 submetidos às doses de magnésio não apresentou diferença significativa para essas doses quando o nitrogênio era de 42 e $210 \mathrm{mg} \mathrm{L}^{-1}$ (Figura 3). Porém houve significância para magnésio com esses dois cultivares quando o nitrogênio estava na solução na dose de $378 \mathrm{mg} \mathrm{L}^{-1}$, sendo mais elevada essa produção com magnésio de $48 \mathrm{mg} \mathrm{L}^{-1}$ que com $4,8 \mathrm{mg} \mathrm{L}^{-1}$. Já no cultivar Vencedor a diferença ocorreu na dose de nitrogênio de $210 \mathrm{mg} \mathrm{L}^{-1}$, sendo a produção mais elevada em presença da dose mais alta de magnésio na solução.

Tabela 2. Produção de matéria seca da parte aérea, no primeiro corte de três cultivares de Panicum, em função das doses de nitrogênio dentro das doses de magnésio empregadas.

\begin{tabular}{|c|l|l|l|}
\hline $\mathbf{N}\left(\mathbf{m g ~ L}^{-1}\right)$ & \multicolumn{1}{|c|}{ Colonião } & \multicolumn{1}{|c|}{ Tanzânia } & \multicolumn{1}{|c|}{ Vencedor } \\
\hline & \multicolumn{3}{|c|}{$\mathbf{M g}=\mathbf{4} \mathbf{~ \mathbf { ~ m ~ L } ^ { - 1 }}$} \\
\hline 42 & $4,44 \mathrm{a}$ & $4,30 \mathrm{a}$ & $3,41 \mathrm{a}$ \\
\hline 210 & $16,54 \mathrm{a}$ & $14,40 \mathrm{ab}$ & $10,61 \mathrm{~b}$ \\
\hline 378 & $15,07 \mathrm{ab}$ & $16,27 \mathrm{a}$ & $12,13 \mathrm{~b}$ \\
\hline & \multicolumn{3}{|c|}{$\mathbf{M g}=\mathbf{4 8} \mathbf{~ m g ~ L}^{-1}$} \\
\hline 42 & $4,27 \mathrm{a}$ & $3,74 \mathrm{a}$ & $3,05 \mathrm{a}$ \\
\hline 210 & $13,65 \mathrm{a}$ & $14,85 \mathrm{a}$ & $13,43 \mathrm{a}$ \\
\hline 378 & $19,81 \mathrm{ab}$ & $22,38 \mathrm{a}$ & $14,00 \mathrm{~b}$ \\
\hline
\end{tabular}

Letras diferentes em cada linha indicam diferença significativa ao nível de $5 \%$ de probabilidade 
Tabela 3. Produção de matéria seca da parte aérea, no segundo corte, dos três cultivares de Panicum em função das doses de nitrogênio dentro das doses de magnésio empregadas.

\begin{tabular}{|c|c|c|c|}
\hline $\mathbf{N}\left(\mathbf{m g ~ L}^{-1}\right)$ & \multicolumn{1}{|c|}{ Colonião } & \multicolumn{1}{|c|}{ Tanzânia } & \multicolumn{1}{|c|}{ Vencedor, $\mathbf{~ m g ~ L}^{-1}$} \\
\hline & \multicolumn{3}{|c|}{} \\
\hline $\mathbf{4 2}$ & $8,68 \mathrm{a}$ & $8,05 \mathrm{a}$ & $7,95 \mathrm{a}$ \\
\hline $\mathbf{2 1 0}$ & $30,89 \mathrm{a}$ & $29,07 \mathrm{a}$ & $27,34 \mathrm{a}$ \\
\hline $\mathbf{3 7 8}$ & $32,34 \mathrm{a}$ & $32,72 \mathrm{a}$ & $30,76 \mathrm{a}$ \\
\hline & \multicolumn{3}{|c|}{$\mathbf{M g = 4 8} \mathbf{~ m g ~ L}^{-1}$} \\
\hline $\mathbf{4 2}$ & $6,96 \mathrm{~b}$ & $12,38 \mathrm{a}$ & $6,48 \mathrm{~b}$ \\
\hline $\mathbf{2 1 0}$ & $32,30 \mathrm{a}$ & $25,97 \mathrm{~b}$ & $31,42 \mathrm{a}$ \\
\hline $\mathbf{3 7 8}$ & $43,89 \mathrm{a}$ & $41,08 \mathrm{ab}$ & $34,89 \mathrm{~b}$ \\
\hline
\end{tabular}

Letras diferentes em cada linha indicam diferença significativa ao nível de 5\% de probabilidade

No segundo corte, os cultivares responderam diferentemente às doses de magnésio dentro das doses de nitrogênio na solução nutritiva (Figura 4). O cultivar Vencedor não mostrou diferença na produção da parte aérea, em função das doses de magnésio, em qualquer das doses de nitrogênio. Quando o nitrogênio estava na solução em 42 e $210 \mathrm{mg} \mathrm{L}^{-1}$ o cultivar Colonião não apresentou diferença significativa para a produção da parte aérea, em função das doses de magnésio, porém na dose de nitrogênio de $378 \mathrm{mg} \mathrm{L}^{-1}$ a produção foi maior quando o magnésio foi fornecido na dose de $48 \mathrm{mg} \mathrm{L}^{-1}$. Já o cultivar Tanzânia-1 teve a produção da parte aérea mais elevada na dose de magnésio de $48 \mathrm{mg} \mathrm{L}^{-1}$, em qualquer das doses de nitrogênio.

Exceto para o Tanzânia-1 no segundo crescimento, não houve significância para as doses de magnésio na produção da parte aérea dos capins quando o 

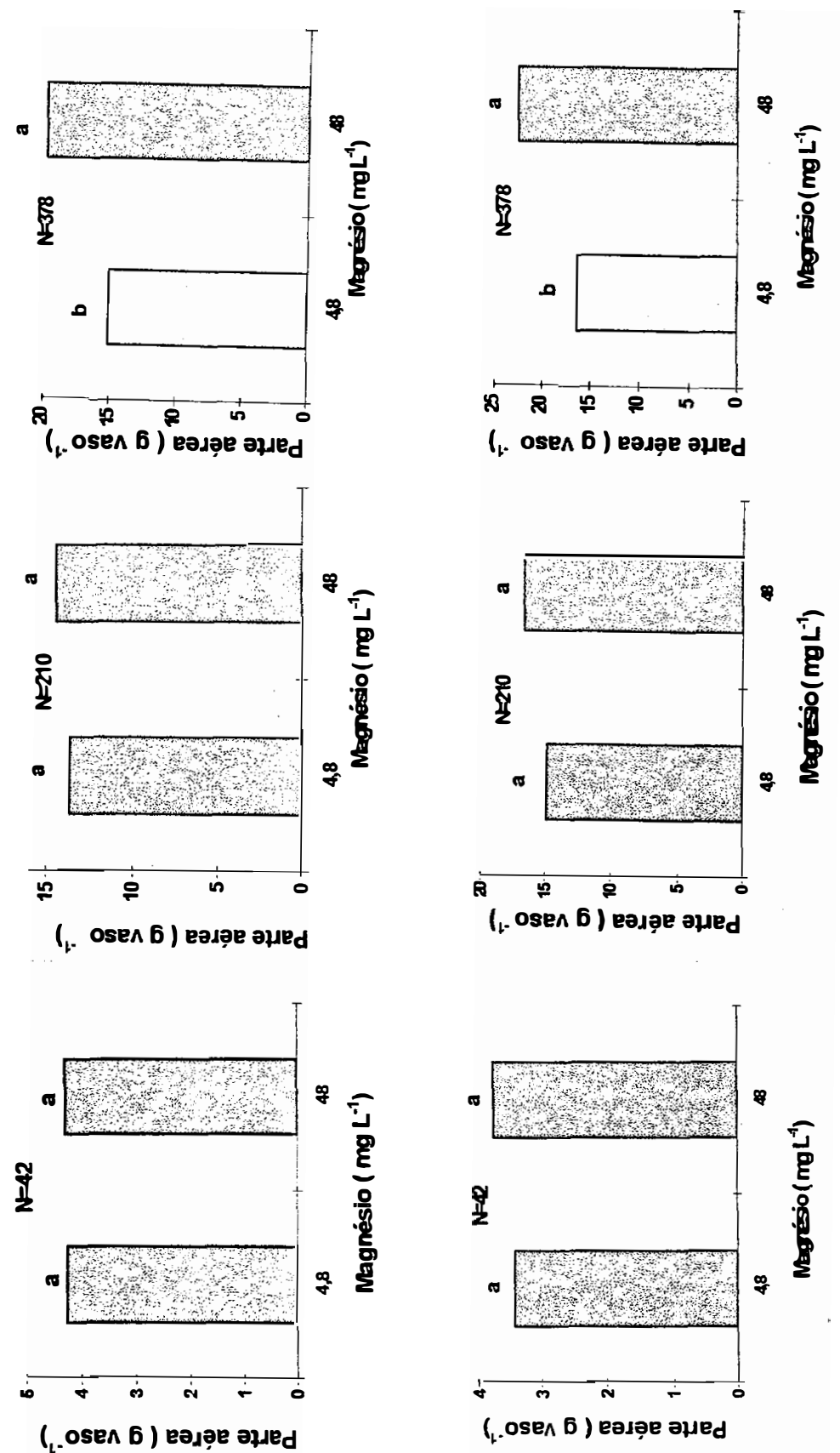

UO-Oz-《O
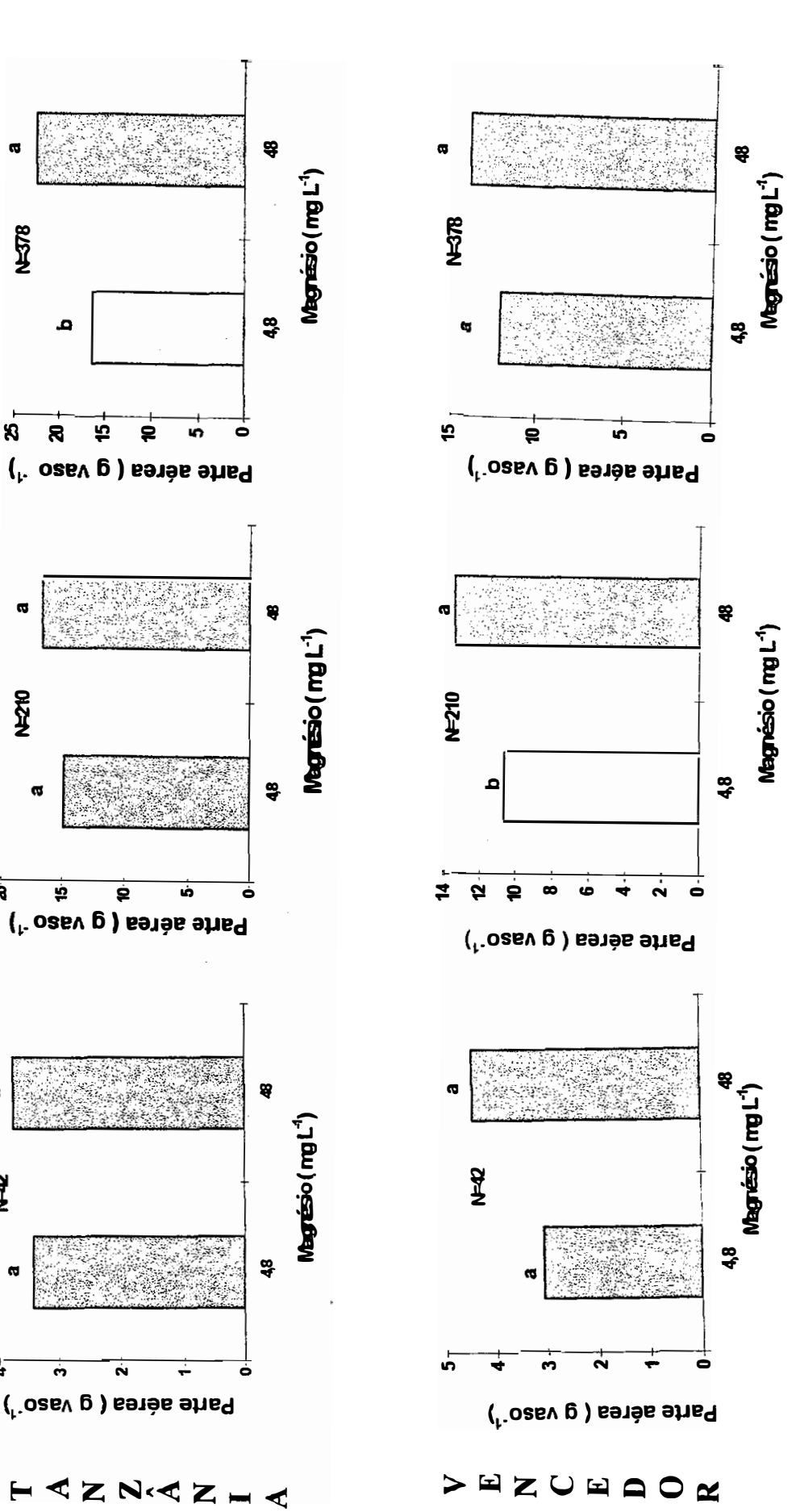

욜

क ह

ญ

ฮ

.

긍

is

음 음

ᄋํำ

$\overline{0} 0$

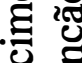

\&

ठ ह

음
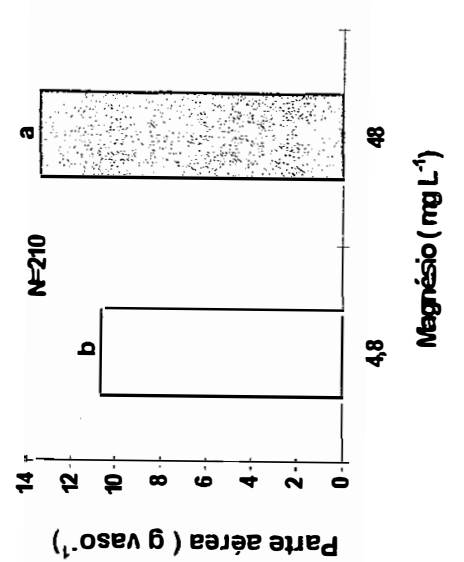

응

응

๕్ర

은.

•

츨

음

की

\&

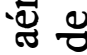

을 흠

츨 월

중

$\pi$

ن 0

- 굴

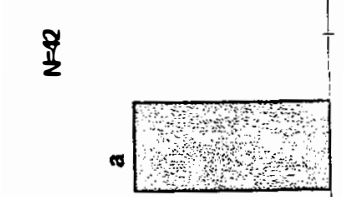

ส․ำ

हु

ธซ్

त्षै

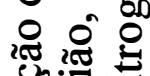

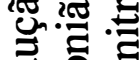

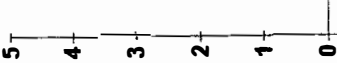

(1, osen 6 ) eajọe əujed

은 응

m

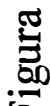


\%
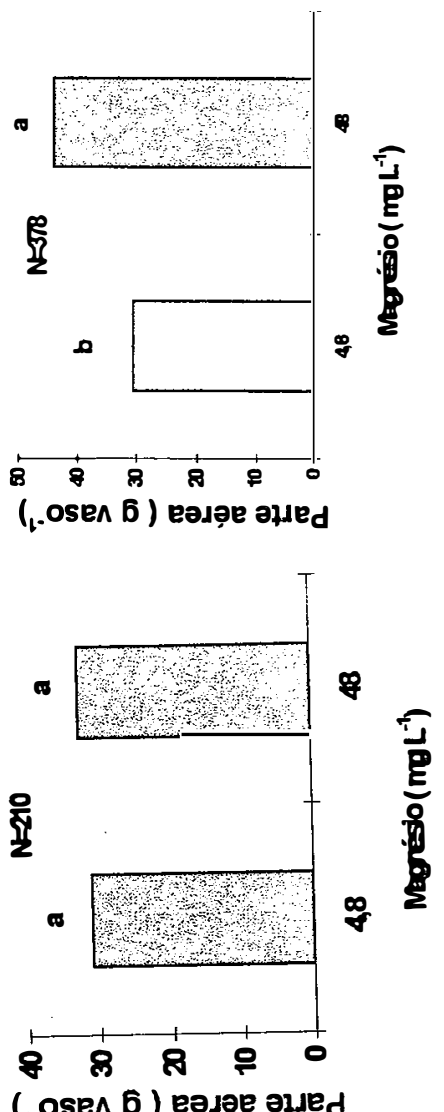

(1.osen 6 ) еәرọe ofued

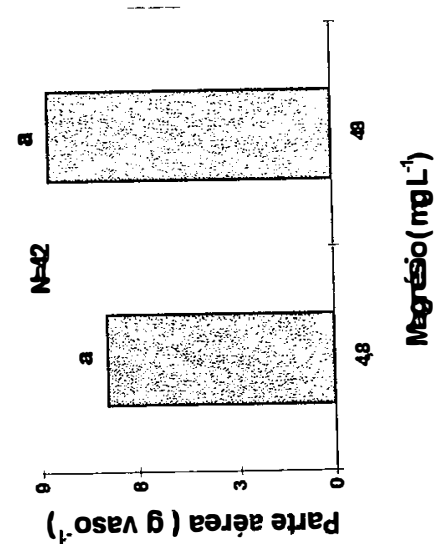

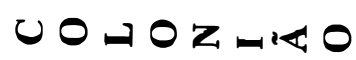
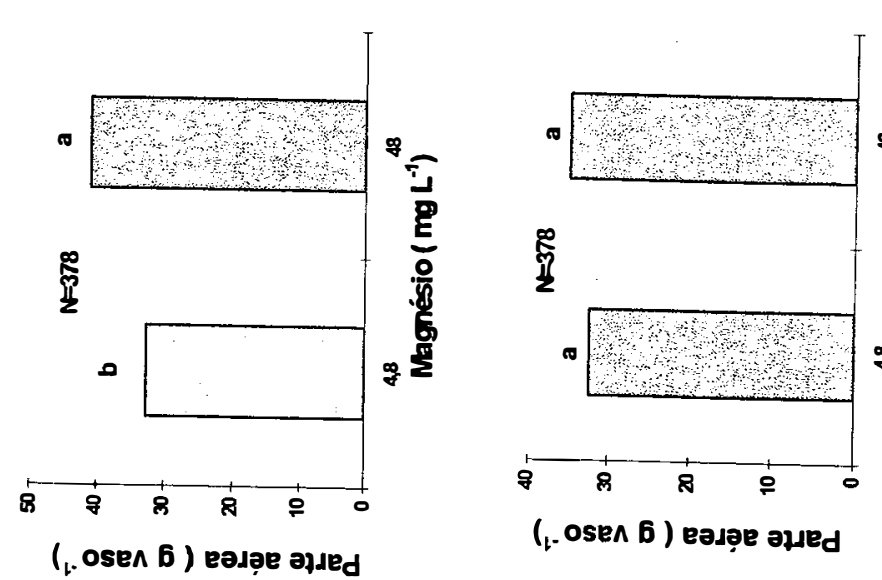

은.운

ह5

窇

\%

7

on

을 유

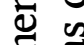

웜

웅

2త్ర

宁

용

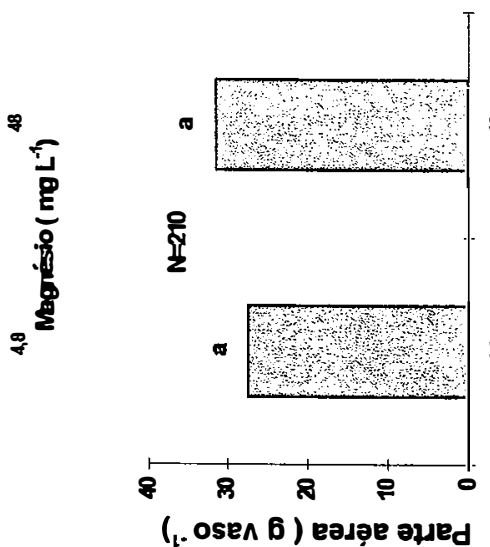

(1. osen 6 ) eajọe әhนеd

\%

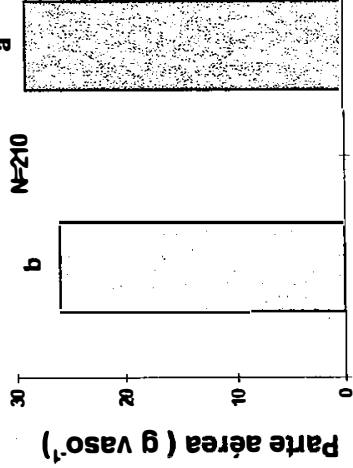

$\circ$

ฮั้

융

路

ช్ర

क ร

오

(

ชึ.

.

$\stackrel{0}{0}$

총

궁

उ

ชี

తึ
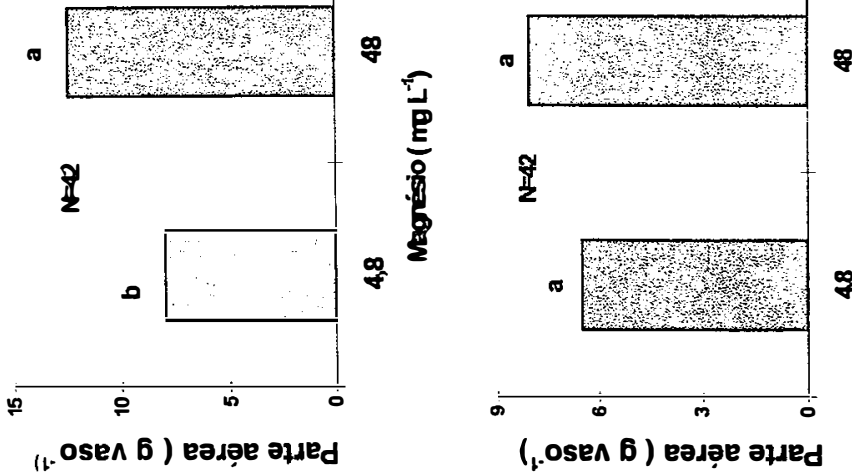

要

is

农

总

㝴

중

en ?

0 잉

플.

는 응 은

$\dot{\nabla}$

전

굴

垔 
nitrogênio foi fornecido na sua dose mais baixa. Isto novamente ressalta o papel importante do fornecimento de nitrogênio para a gramínea forrageira.

Muito poucos resultados tem sido publicados com referência à influência do magnésio na produção de matéria seca de forrageiras, porém ficou evidente neste experimento que o cultivar Tanzânia-1 teve a sua produção da parte aérea incrementada pela maior adição de magnésio à solução nutritiva, em qualquer dose de nitrogênio utilizada.

\subsection{Produção de matéria seca de raízes}

A produção de matéria seca das raízes também apresentou interação significativa entre as três variáveis estudadas. As produções de matéria seca de raízes dos cultivares Colonião e Vencedor apresentaram ajustes ao modelo quadrático em função das doses de nitrogênio na solução nutritiva em ambas das doses de magnésio empregadas. O cultivar Tanzânia-1, por sua vez, teve sua produção de raízes ajustada ao modelo quadrático na dose de magnésio de 4,8 $\mathrm{mg}$ $\mathrm{L}^{-1}$ e a uma função do primeiro grau na dose de $48 \mathrm{mg} \mathrm{L}^{-1}$, para as respostas às doses de nitrogênio na solução (Figura 5).

Dentro dos níveis de nitrogênio de 42 e $210 \mathrm{mg} \mathrm{L}^{-1}$ os três cultivares não diferiram significativamente entre si, quanto à produção de matéria seca das raízes, em qualquer das doses de magnésio utilizadas (Tabela 4). Na dose de nitrogênio de $378 \mathrm{mg} \mathrm{L}^{-1}$, nas duas doses de magnésio, o cultivar Vencedor apresentou produção de raízes inferior ao Tanzânia-1. O cultivar Vencedor também teve produção de raízes inferior ao cultivar Colonião, na dose de nitrogênio $378 \mathrm{mg} \mathrm{L}^{-1}$, em presença da dose de magnésio de $48 \mathrm{mg} \mathrm{L}^{-1}$. Como destacado anteriormente quando o nitrogênio é fornecido na sua dose mais baixa 


\section{COLONIÃO}
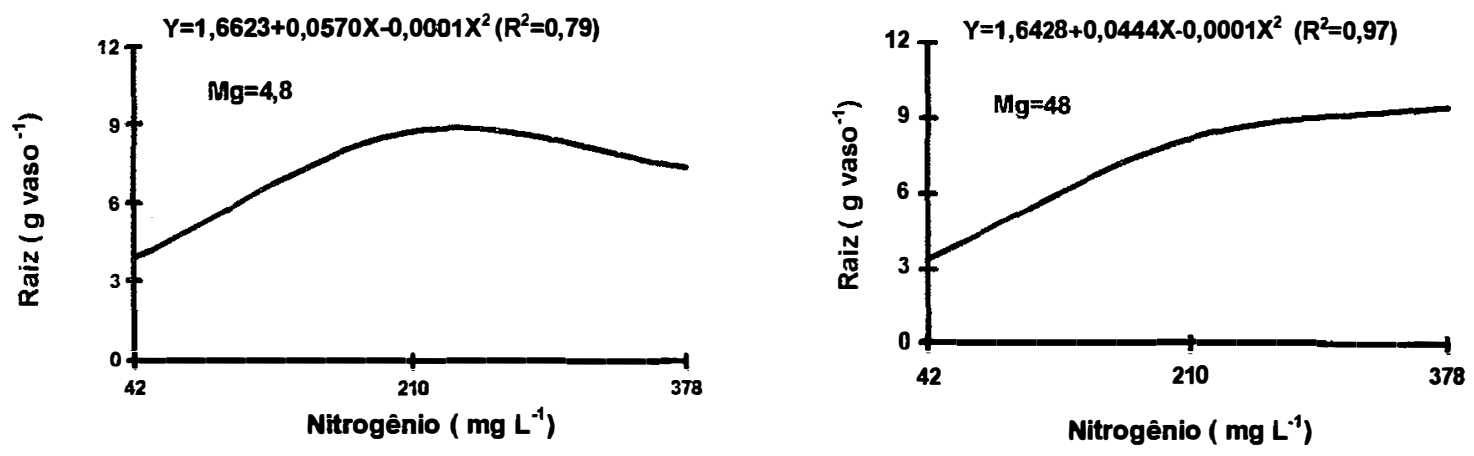

TANZÂNIA-1
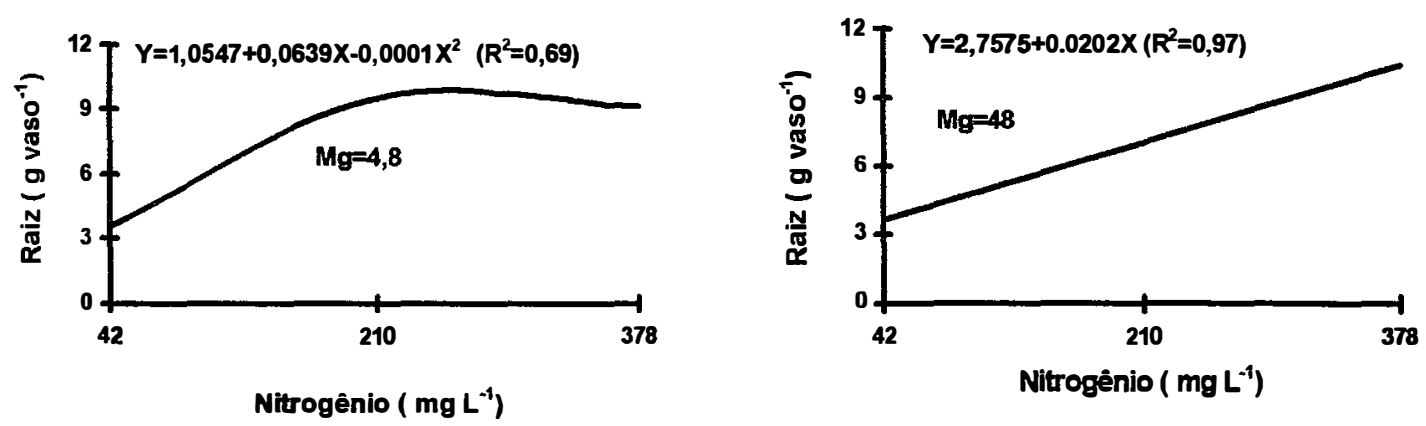

\section{VENCEDOR}
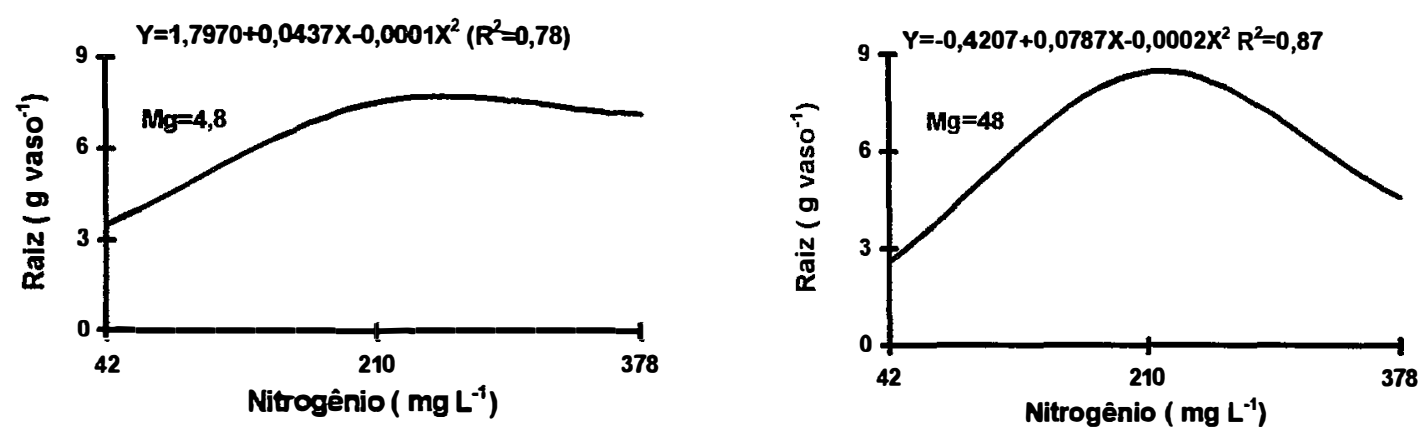

Figura 5. Produção da matéria seca das raízes, no segundo período, dos cultivares Colonião, Tanzânia-1 e Vencedor de Panicum maximum Jacq, em função das doses de nitrogênio dentro das doses de magnésio. 
os cultivares não apresentam diferenças quando submetidos às doses de magnésio, ressaltando a importância deste elemento na nutrição das forrageiras e consequente expressão do seu potencial.

Para o cultivar Tanzânia-1 não houve diferença significativa na produção de matéria seca das raízes, em função das doses de magnésio, em qualquer das doses de nitrogênio empregadas (Figura 6). Os cultivares Colonião e Vencedor não apresentaram diferenças significativas na produção de matéria seca das raízes, em presença da dose de nitrogênio de 42 e $210 \mathrm{mg} \mathrm{L}^{-1}$, quando submetidos às duas doses de magnésio. Porém quando se empregou o nitrogênio na dose de 378 $\mathrm{mg} \mathrm{L}^{-1}$ a produção das raízes foi diferente, conforme a dose de magnésio, em ambos os cultivares.

Tabela 4. Produção de matéria seca das raízes de três cultivares de Panicum em função das doses de nitrogênio, dentro das doses de magnésio empregadas.

\begin{tabular}{|c|l|l|l|}
\hline $\mathbf{N}$ Colonião & \multicolumn{1}{|c|}{ Tanzânia } & \multicolumn{1}{|c|}{ Vencedor $\left.\mathbf{~}^{-1}\right)$} \\
\hline & \multicolumn{3}{|c|}{ Mg=4,8 $\mathbf{~ m g ~ L}^{-1}$} \\
\hline $\mathbf{4 2}$ & $3,86 \mathrm{a}$ & $3,54 \mathrm{a}$ & $3,50 \mathrm{a}$ \\
\hline $\mathbf{2 1 0}$ & $9,51 \mathrm{a}$ & $8,77 \mathrm{a}$ & $7,53 \mathrm{a}$ \\
\hline $\mathbf{3 7 8}$ & $7,46 \mathrm{ab}$ & $9,14 \mathrm{a}$ & $7,15 \mathrm{~b}$ \\
\hline & \multicolumn{3}{|c|}{$\mathbf{M g}=\mathbf{4 8} \mathbf{~ m g ~ L}^{-1}$} \\
\hline $\mathbf{4 2}$ & $3,40 \mathrm{a}$ & $3,09 \mathrm{a}$ & $2,58 \mathrm{a}$ \\
\hline $\mathbf{2 1 0}$ & $8,46 \mathrm{a}$ & $8,21 \mathrm{a}$ & $8,03 \mathrm{a}$ \\
\hline $\mathbf{3 7 8}$ & $9,49 \mathrm{a}$ & $9,87 \mathrm{a}$ & $4,58 \mathrm{~b}$ \\
\hline
\end{tabular}

Letras diferentes em cada linha indicam diferença significativa ao nível de $5 \%$ de probabilidade 

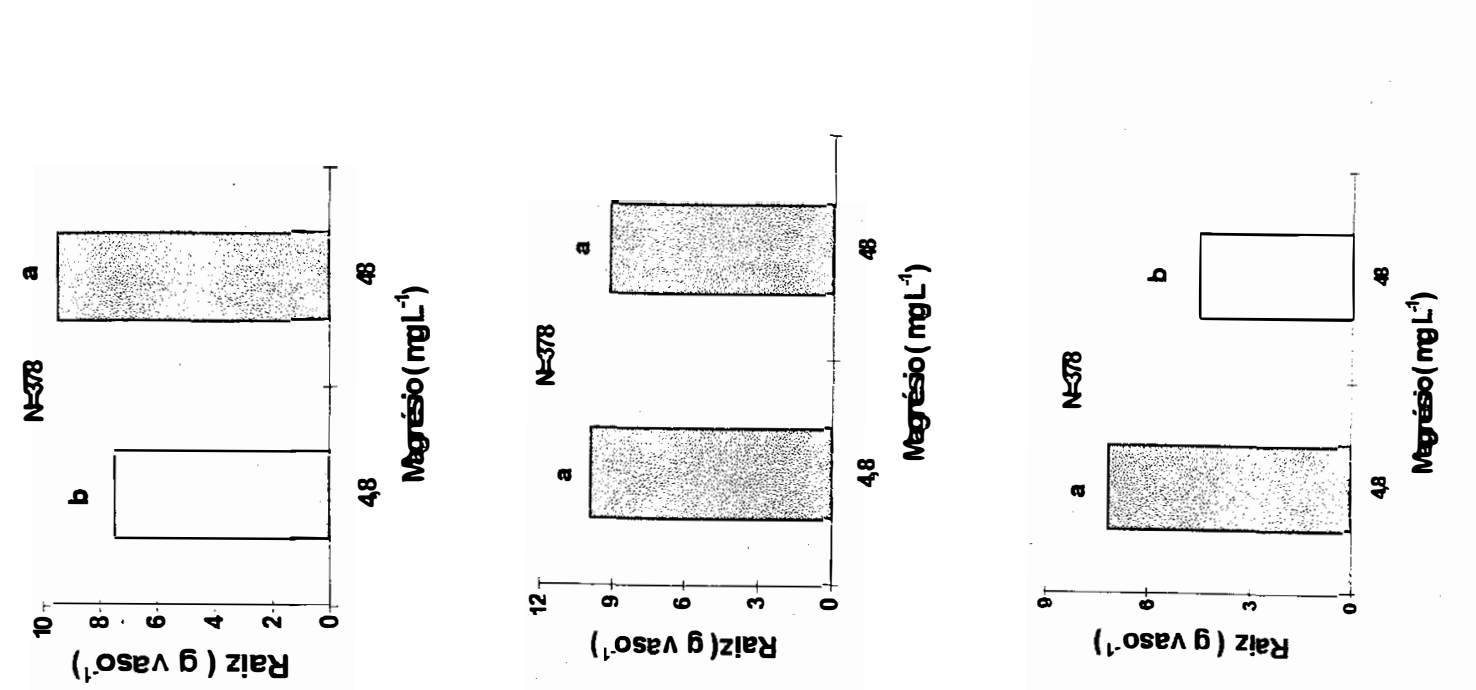

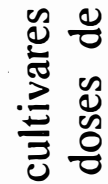
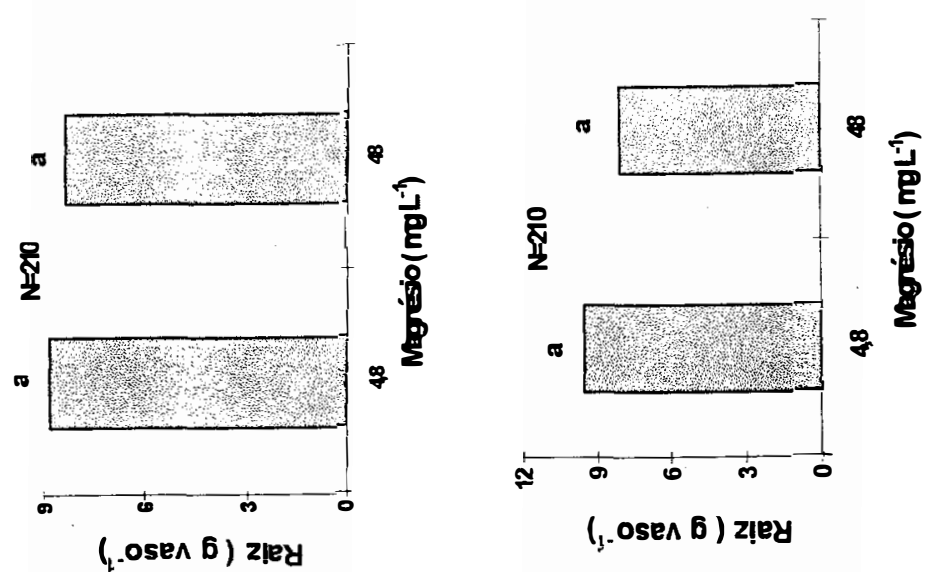

응 홍

屬

ช

응
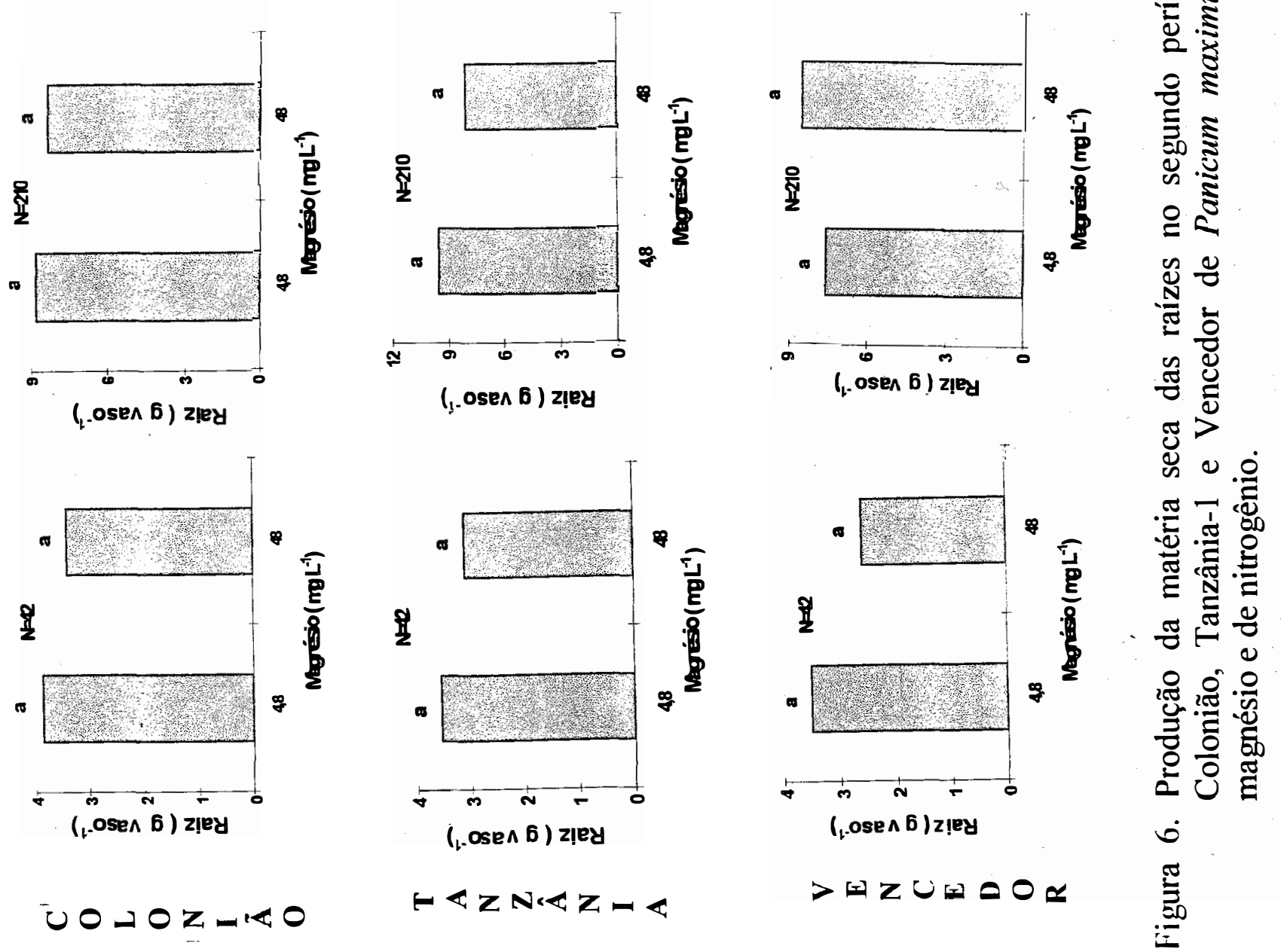


\subsection{Número de perfilhos}

O número de perfilhos nas cinco plantas foi significativamente influenciado pelas doses de nitrogênio utilizadas, mas não variou com os três cultivares de Panicum maximum estudados e não sofreu influência significativa dos níveis de magnésio empregados.

Tanto no primeiro como no segundo períodos de crescimento o número de perfilhos aumentou da dose de nitrogênio de $42 \mathrm{mg} \mathrm{L}^{-1}$ para a $210 \mathrm{mg} \mathrm{L}^{-1}$, não variando entre 210 e $378 \mathrm{mg} \mathrm{L}^{-1}$ (Figura 7).

1ํㅡ문

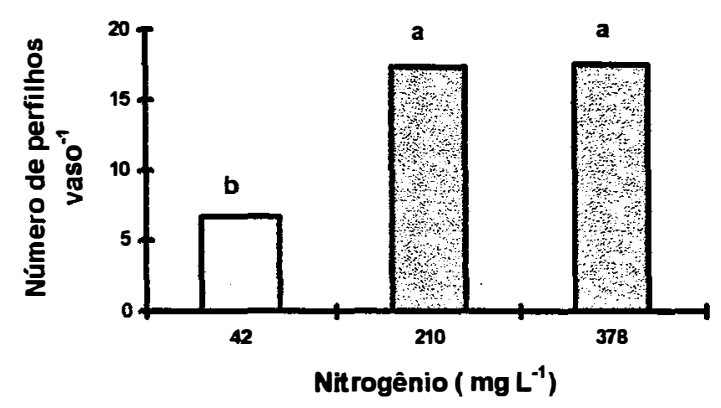

2o CORTE

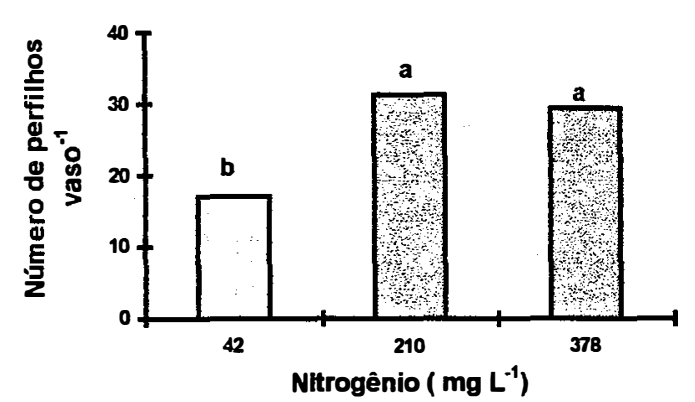

Figura 7.Número médio de perfilhos nos três cultivares de Panicum maximum Jacq, no primeiro e no segundo crescimento, em função das doses de nitrogênio dentro das doses de magnésio.

No primeiro crescimento, o número médio de perfilhos foi menor que no segundo pois na primeira fase a planta está em estabelecimento e com formação do sistema radicular, enquanto na segunda fase o sistema radicular foi mantido, $o$ que certamente facilitou o perfilhamento. A presença de gemas, cerca de 1 a 3 por perfilho, que são mantidas por ocasião do $2^{\mathrm{o}}$ corte deve também ter facilitado o desenvolivimento dos perfilhos. 
O efeito do nitrogênio sobre o número de perfilhos encontrado no presente trabalho confirma a importância do nitrogênio no estabelecimento das pastagens e consequente fechamento do terreno. Resultados semelhantes foram encontrados por Werner et al. (1967); Monteiro e Werner (1977); Abreu (1994) e Santos et al. (1995) com cultivares de Panicum e fornecendo doses de nitrogênio no meio de crescimento.

\subsection{Atividade da redutase do nitrato}

Nos dois períodos de crescimento houve interação tripla significativa entre os cultivares, as doses de nitrogênio e as doses de magnésio para a atividade da redutase do nitrato. No primeiro corte a atividade da redutase do nitrato, no cultivar Colonião, em função das doses de nitrogênio se ajustou a um modelo quadrático, quando a dose de magnésio era de $4,8 \mathrm{mg} \mathrm{L}^{-1}$ e a um modelo linear quando o magnésio estava presente em $48 \mathrm{mg} \mathrm{L}^{-1}$. No cultivar Tanzânia-1 os ajustes para essa atividade enzimática às doses de nitrogênio se deram a modelos quadráticos em ambas as concentrações de magnésio na solução. No cultivar Vencedor essa atividade enzimática cresceu linearmente com as doses de nitrogênio, em presença de baixa dose de magnésio na solução, mas seguiu um modelo quadrático na dose mais elevada de magnésio (Figura 8). 


\section{COLONIÃO}
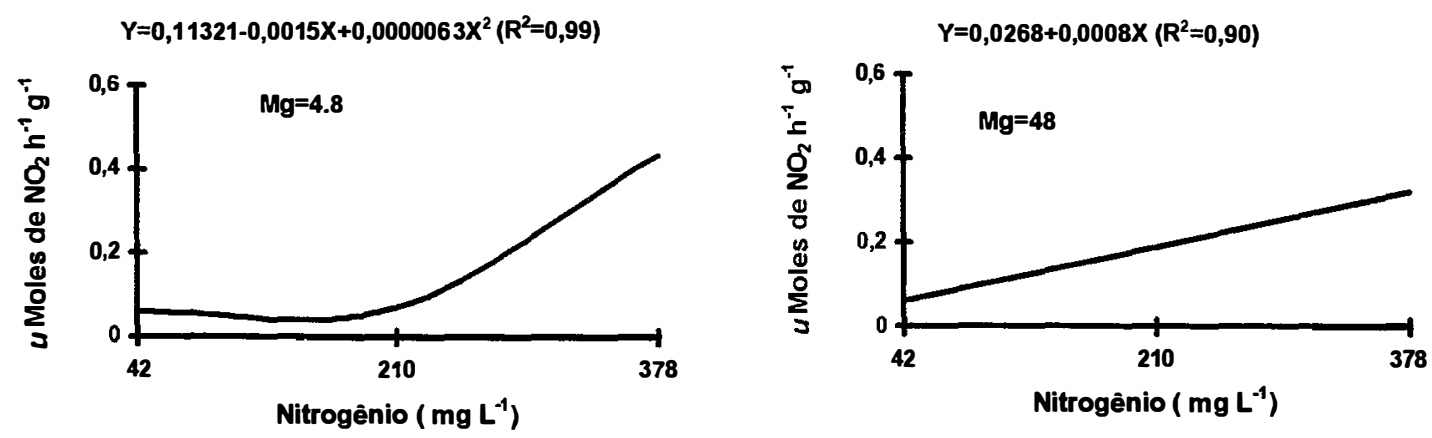

\section{TANZÂNIA-1}
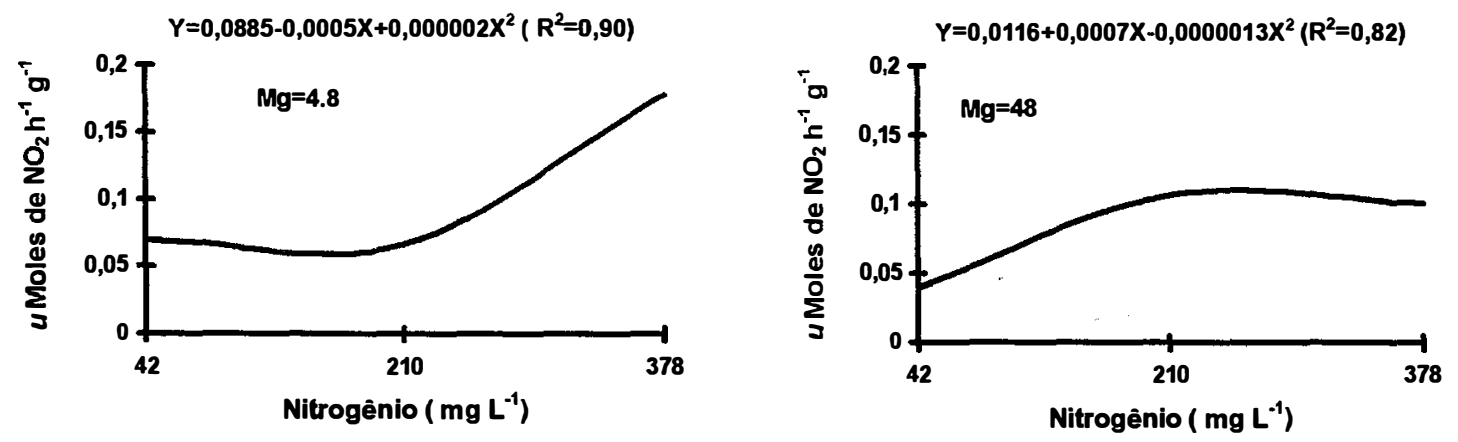

VENCEDOR
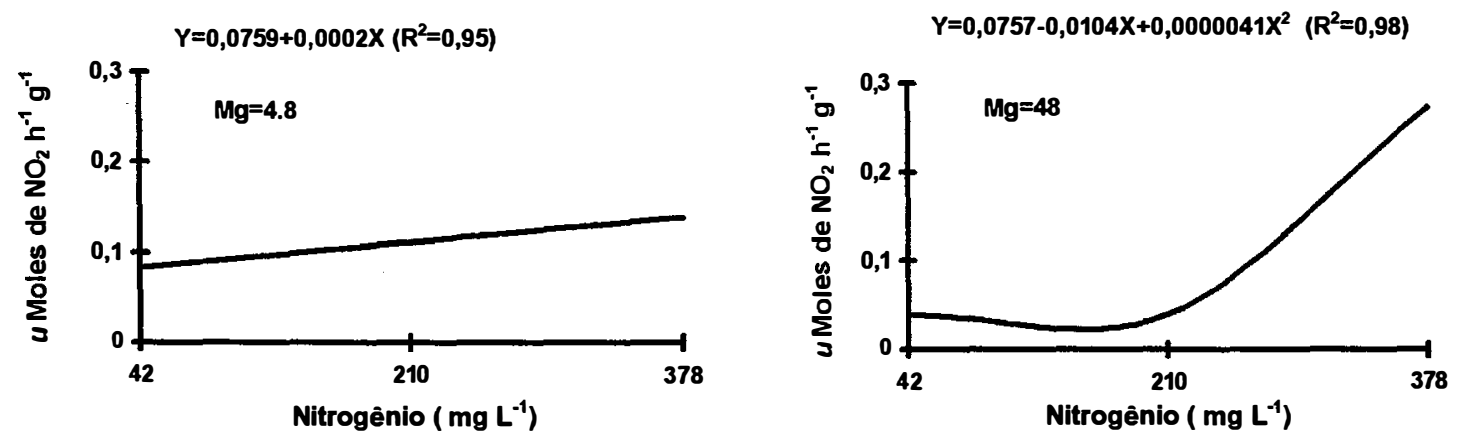

Figura 8. Atividade da enzima redutase do nitrato, no primeiro período de crescimento, dos cultivares Colonião, Tanzânia-1 e Vencedor de Panicum maximum Jacq, em função das doses de nitrogênio, dentro das doses de magnésio. 
Houve sempre um aumento na atividade desta enzima em função do incremento nos níveis de nitrogênio acima de $210 \mathrm{mg} \mathrm{L}^{-1}$, independente da dose de magnésio e do cultivar empregado. Estes resultados concordam com os encontrados na literatura destacando a importância do nitrogênio na expressão da atividade da redutase do nitrato ( Shen et al.,1993; Abreu, 1994).

A atividade da redutase do nitrato foi mais expressiva do que aquela verificada por Abreu (1994), que os considerou baixos devido a época de amostragem. No presente experimento as amostragens foram feitas aos 27 e 26 dias no primeiro e no segundo crescimentos, respectivamente, sendo que aquele autor avaliou essa atividade aos 46 dias de crescimento da forrageira.

No segundo corte a atividade da redutase do nitrato no cultivar Colonião, dentro da dose de magnésio de $4,8 \mathrm{mg} \mathrm{L}^{-1}$ e o cultivar Tanzânia-1, dentro das duas doses de magnésio, não variou significativamente com as doses de nitrogênio. A atividade desta enzima se ajustou a um modelo quadrático no cultivar Colonião, dentro da dose de magnésio $48 \mathrm{mg} \mathrm{L}^{-1}$ e a modelos lineares no cultivar Vencedor ( Figura 9). Neste crescimento o nitrogênio teve um efeito depressivo na atividade desta enzima. 


\section{COLONIÃO}

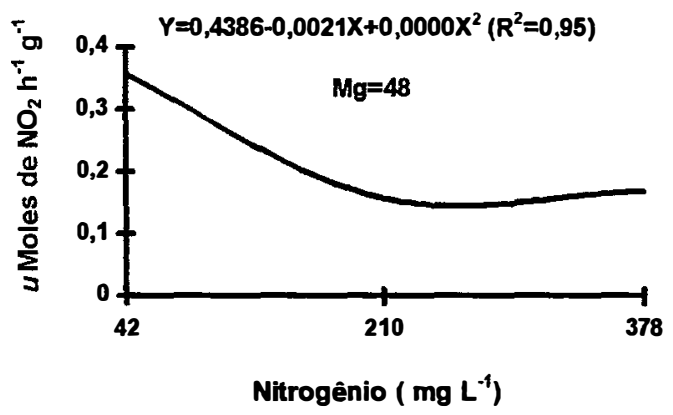

VENCEDOR
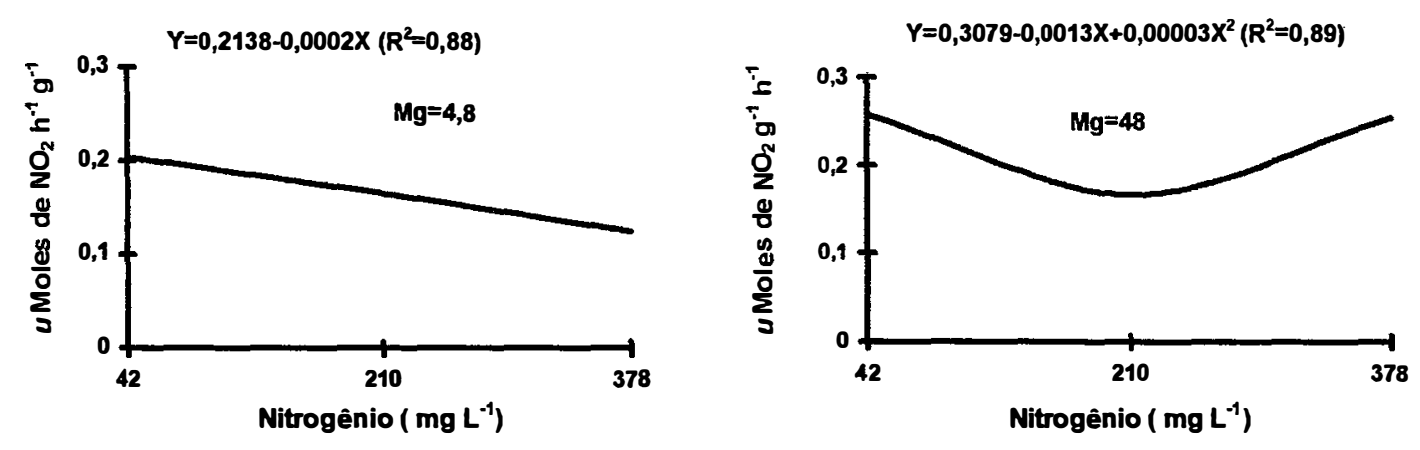

Figura 9. Atividade da enzima redutase do nitrato, no segundo período de crescimento, dos cultivares Colonião e Vencedor de Panicum maximum Jacq, em função das doses de nitrogênio, dentro das doses de magnésio.

$\mathrm{Na}$ dose de nitrogênio $42 \mathrm{mg} \mathrm{L}^{-1}$, independente da dose de magnésio, os cultivares não apresentaram diferenças entre si na atividade da redutase do nitrato (Tabela 5). Quando o nível de nitrogênio fornecido foi de $210 \mathrm{mg} \mathrm{L}^{-1}$ ocorreram diferenças entre os cultivares e, dentro da dose de magnésio de $4,8 \mathrm{mg} \mathrm{L}^{-1}$, o cultivar Vencedor apresentou atividade desta enzima superior aos outros cultivares utilizados. Na dose de magnésio de $48 \mathrm{mg} \mathrm{L}^{-1}$ e nitrogênio de $210 \mathrm{mg}$ $\mathrm{L}^{-1}$, o cultivar Colonião mostrou-se superior aos outros dois cultivares. Na maior 
dose de nitrogênio na solução nutritiva, o cultivar Tanzânia-1 teve atividade dessa enzima inferior aos outros dois cultivares.

Tabela 5. Atividade da redutase do nitrato no primeiro corte em três cultivares de Panicum, em função das doses de nitrogênio, dentro das doses de magnésio empregadas.

\begin{tabular}{|c|l|l|l|}
\hline $\mathbf{N}\left(\mathbf{m g ~ L}^{-1}\right)$ & \multicolumn{1}{|c|}{ Colonião } & \multicolumn{1}{|c|}{ Tanzânia } & \multicolumn{1}{|c|}{ Vencedor $\mathbf{3} \mathbf{~ m g ~ L}^{-1}$} \\
\hline & \multicolumn{3}{|c|}{} \\
\hline $\mathbf{4 2}$ & $0,06 \mathrm{a}$ & $0,07 \mathrm{a}$ & $0,08 \mathrm{a}$ \\
\hline $\mathbf{2 1 0}$ & $0,07 \mathrm{~b}$ & $0,07 \mathrm{~b}$ & $0,12 \mathrm{a}$ \\
\hline $\mathbf{3 7 8}$ & $0,43 \mathrm{a}$ & $0,18 \mathrm{~b}$ & $0,13 \mathrm{~b}$ \\
\hline & & \multicolumn{3}{|c|}{$\mathbf{M g = 4 8} \mathbf{~ m g ~ L}^{-1}$} \\
\hline $\mathbf{4 2}$ & $0,05 \mathrm{a}$ & $0,04 \mathrm{a}$ & $0,04 \mathrm{a}$ \\
\hline $\mathbf{2 1 0}$ & $0,21 \mathrm{a}$ & $0,11 \mathrm{~b}$ & $0,04 \mathrm{~b}$ \\
\hline 378 & $0,31 \mathrm{a}$ & $0,10 \mathrm{~b}$ & $0,27 \mathrm{a}$ \\
\hline
\end{tabular}

Letras diferentes em cada linha indicam diferença significativa ao nível de $5 \%$ de probabilidade

Em relação às doses de magnésio nenhum dos cultivares utilizados apresentou diferenças na atividade da redutase do nitrato na dose de nitrogênio de $42 \mathrm{mg} \mathrm{L}^{-1}$ (Figura 10). Quando o nitrogênio fornecido foi de $210 \mathrm{mg} \mathrm{L}^{-1}$, os cultivares Colonião e Tanzânia-1 apresentaram maiores atividades quando o magnésio estava em $48 \mathrm{mg} \mathrm{L}^{-1}$ de solução, enquanto que para o Vencedor o comportamento foi inverso. No nível de nitrogênio de $378 \mathrm{mg} \mathrm{L}^{-1}$ somente o cultivar Tanzânia-1 não respondeu significativamente à variação no fornecimento de magnésio na solução nutritiva, enquanto que o Colonião e Vencedor demonstraram comportamentos inversos, apresentando a atividade maior, no 


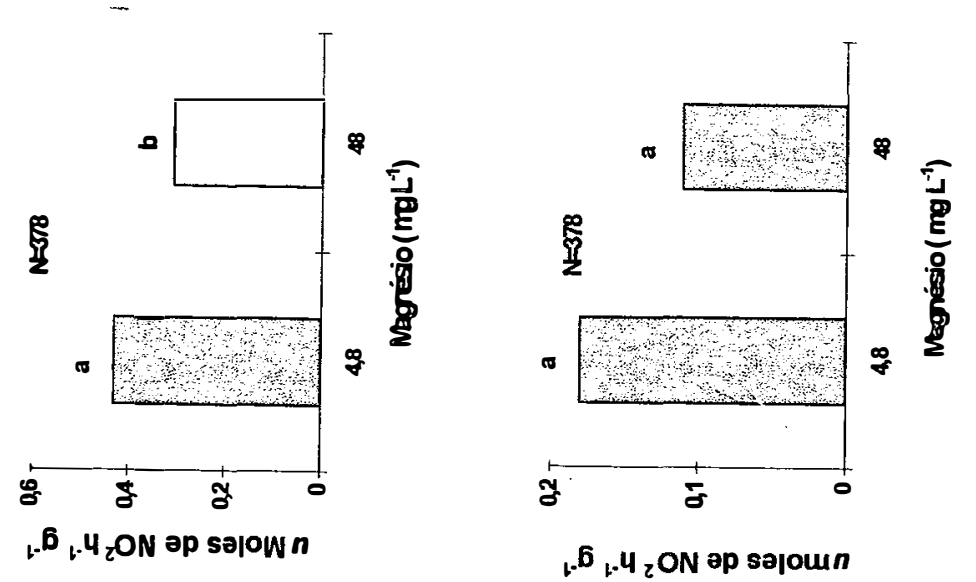

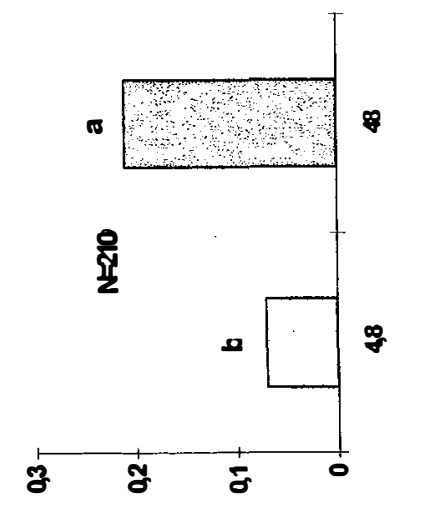
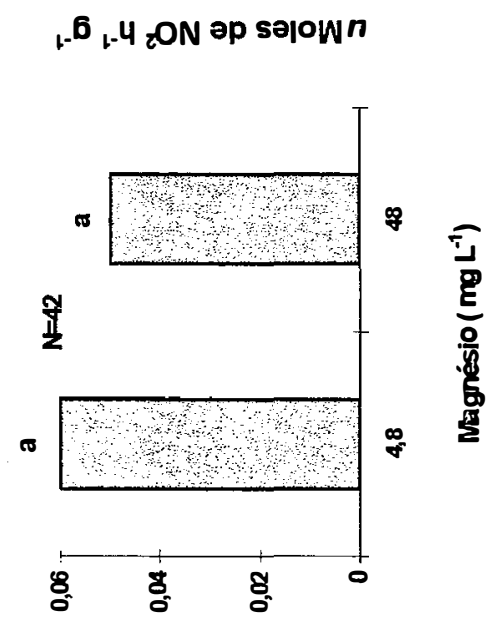

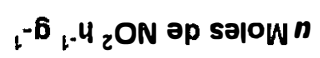

U נO

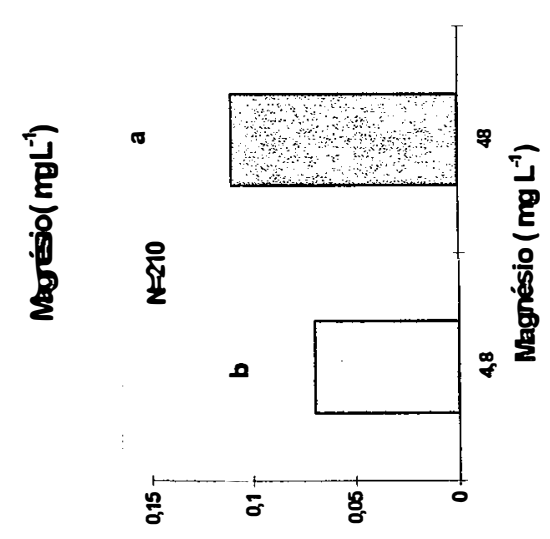

เ.6 ${ }_{1} .4{ }_{2}$ ON op selOWn

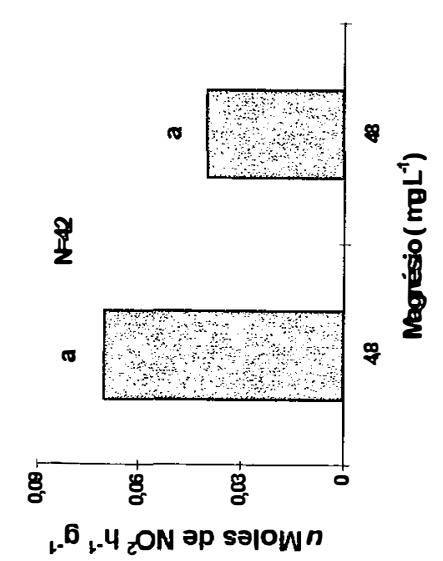

$\because \ll Z N \ll Z m \varangle$

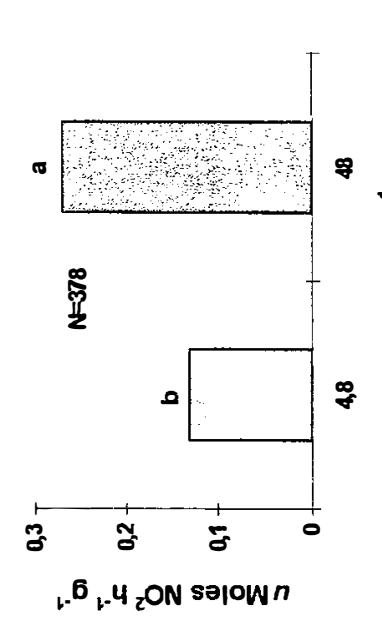

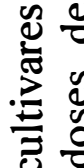

ㅇํㅁ ซึ ช

苋

影

บै

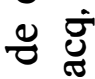

융

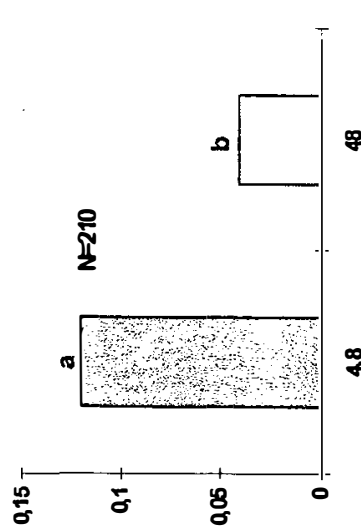

(1.6 1.4 ZON OP salOwn

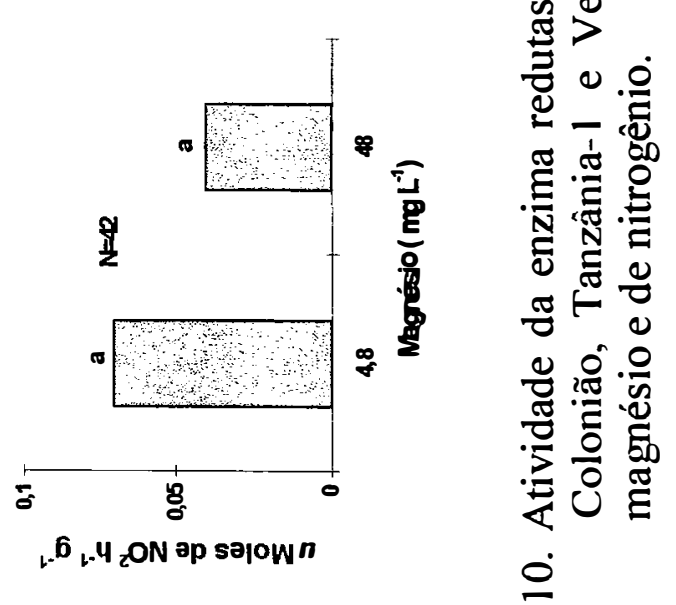

$>$ 지넝

可 
Colonião quando a dose de magnésio fornecida foi de $4,8 \mathrm{mg} \mathrm{L}^{-1}$ e no Vencedor quando era de $48 \mathrm{mg} \mathrm{L}^{-1}$.

No segundo período de crescimento quando o nitrogênio fornecido foi de $42 \mathrm{mg} \mathrm{L}^{-1}$ somente o cultivar Colonião respondeu significativamente às doses de magnésio, na dose de nitrogênio de $210 \mathrm{mg} \mathrm{L}^{-1}$ não ocorreram diferenças e na dose mais elevada ( $378 \mathrm{mg} \mathrm{L}^{-1}$ ) os três cultivares se comportaram da mesma maneira, apresentando atividades da redutase do nitrato mais elevadas quando a dosé de magnésio fornecida foi de $48 \mathrm{mg} \mathrm{L}^{-1}$ (Figura 11).

Pode-se notar, na tabela 6, que quando o nívelde nitrogênio é alto ( $378 \mathrm{mg}$ $\left.\mathrm{L}^{-1}\right)$ os cultivares não apresentam diferença na atividade desta enzima, porém quando são fornecidas as outras doses de nitrogênio existem diferenças.

Tabela 6. Atividade da redutase do nitrato no segundo período de crescimento dos três cultivares Colonião, Tanzânia-1 e Vencedor de Panicum em função das doses de nitrogênio, dentro das doses de magnésio empregadas.

\begin{tabular}{|c|l|l|l|}
\hline $\mathbf{N}\left(\mathbf{m g ~ L}^{-1}\right)$ & \multicolumn{1}{|c|}{ Colonião } & \multicolumn{1}{|c|}{ Tanzânia } & \multicolumn{1}{|c|}{ Vencedor } \\
\hline & \multicolumn{3}{|c|}{$\mathbf{M g}=\mathbf{4 , 8} \mathbf{~ m g ~ L}^{-1}$} \\
\hline 42 & $0,15 \mathrm{a}$ & $0,15 \mathrm{a}$ & $0,22 \mathrm{a}$ \\
\hline $\mathbf{2 1 0}$ & $0,17 \mathrm{a}$ & $0,12 \mathrm{~b}$ & $0,14 \mathrm{ab}$ \\
\hline $\mathbf{3 7 8}$ & $0,11 \mathrm{a}$ & $0,12 \mathrm{a}$ & $0,14 \mathrm{a}$ \\
\hline & & \multicolumn{3}{|c|}{$\mathbf{M g}=\mathbf{4 8} \mathbf{~ m g ~ L}^{-1}$} \\
\hline $\mathbf{4 2}$ & $0,36 \mathrm{a}$ & $0,15 \mathrm{~b}$ & $0,26 \mathrm{a}$ \\
\hline $\mathbf{2 1 0}$ & $0,16 \mathrm{a}$ & $0,14 \mathrm{a}$ & $0,17 \mathrm{a}$ \\
\hline $\mathbf{3 7 8}$ & $0,17 \mathrm{a}$ & $0,17 \mathrm{a}$ & $0,17 \mathrm{a}$ \\
\hline
\end{tabular}

Letras diferentes em cada linha indicam diferença significativa ao nível de $5 \%$ de probabilidade 

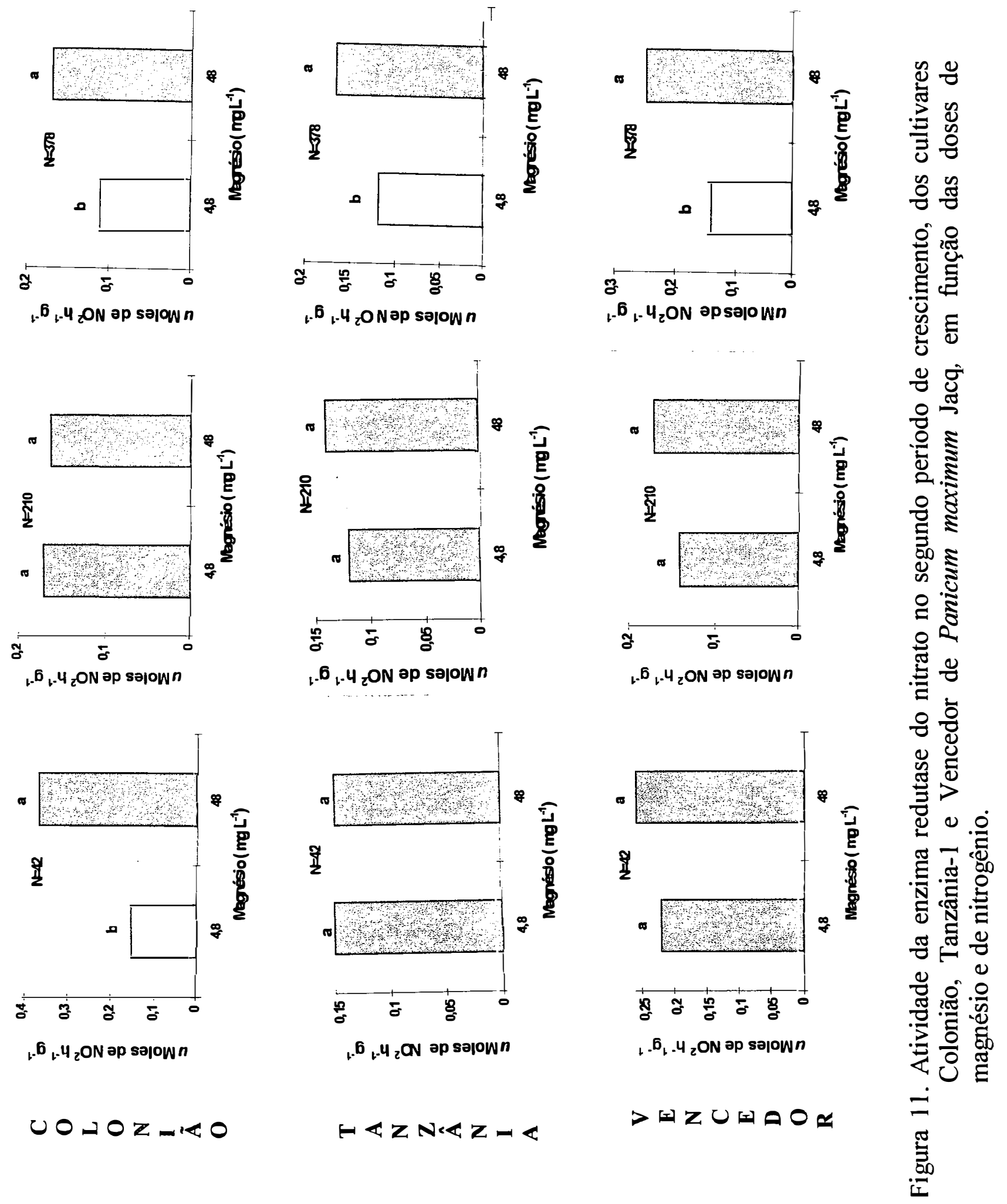


\subsection{Atividade da glutamina sintetase}

Por ocasião do primeiro corte das plantas, ocorreu significância para a interação entre as doses de nitrogênio e os cultivares utilizados, em termos da atividade da enzima glutamina sintetase. Não houve efeitos das doses de magnésio, o que discorda da literatura disponível, tal como O'neal e Joy (1974).

Os dados referentes a atividade desta enzima no capim Vencedor ajustaram-se a um modelo quadrático de regressão em função das doses de nitrogênio utilizadas, enquanto que os outros dois cultivares não apresentaram efeito significativo para as doses desse nutriente na solução nutritiva ( Figura 12).

A atividade da glutamina sintetase no primeiro crescimento foi diferente entre os cultivares somente quando a dose de nitrogênio foi o mais elevado ( 378 $\mathrm{mg} \mathrm{L}^{-1}$ ), sendo que no cultivar Tanzânia-1 foi sigificativamente superior (Tabela 7).

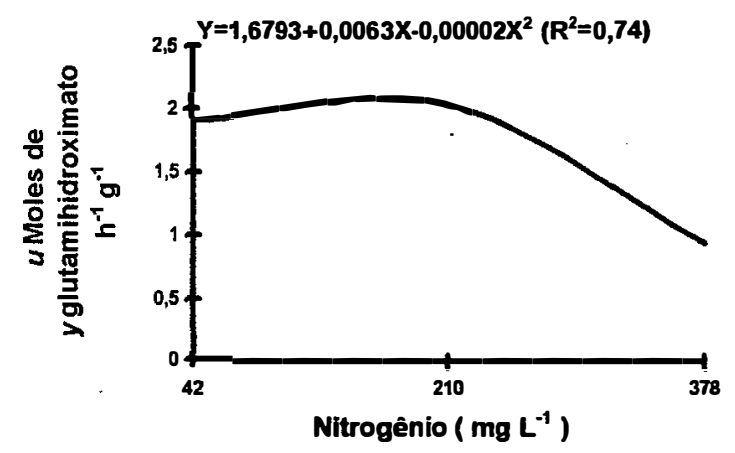

Figura 12. Atividade da enzima glutamina sintetase, no primeiro período de crescimento do cultivar Vencedor de Panicum maximum Jacq, em função das doses de nitrogênio. 
Tabela 7. Atividade da glutamina sintetase, no primeiro crescimento, em três cultivares de Panicum em função das doses de nitrogênio empregadas, na média das doses de magnésio.

\begin{tabular}{|c|l|l|l|}
\hline $\mathbf{N}\left(\mathbf{m g ~ L}^{-1}\right)$ & \multicolumn{1}{|c|}{ Colonião } & \multicolumn{1}{|c|}{ Tanzânia } & \multicolumn{1}{|c|}{ Vencedor } \\
\hline 42 & $1,77 \mathrm{a}$ & $1,67 \mathrm{a}$ & $1,90 \mathrm{a}$ \\
\hline 210 & $1,68 \mathrm{a}$ & $1,93 \mathrm{a}$ & $2,03 \mathrm{a}$ \\
\hline 378 & $1,41 \mathrm{ab}$ & $1,69 \mathrm{a}$ & $0,93 \mathrm{~b}$ \\
\hline
\end{tabular}

Letras diferentes em cada linha indicam diferença significativa ao nível de $5 \%$ de probabilidade

À época do segundo corte das forrageiras, a atividade desta enzima somente sofreu efeitos significativos das doses de nitrogênio empregadas, ajustando-se a um modelo quadrático de regressão (Figura 13).

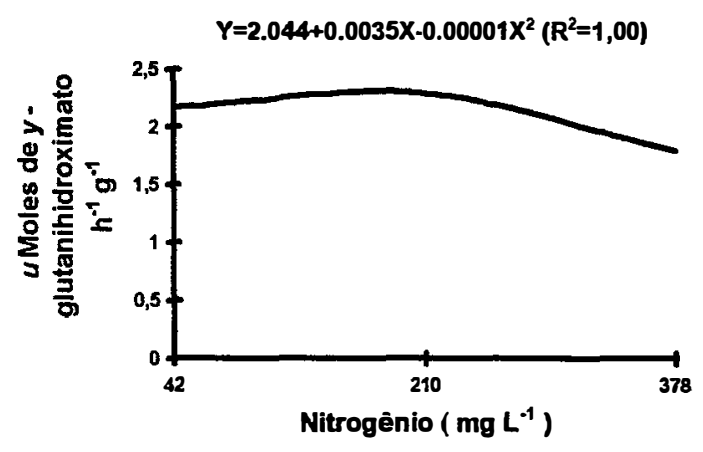

Figura 13. Atividade da enzima glutamina sintetase média para os três cultivares, no segundo período de crescimento, em função das doses de nitrogênio. 


\subsection{Concentração de nitrogênio nos tecidos vegetais}

\subsubsection{Folhas novas}

No primeiro crescimento a concentração de nitrogênio nas folhas novas das forrageiras apresentou interação significativa entre as doses de nitrogênio e as de magnésio. Nas duas doses de magnésio estudadas o ajuste ocorreu para modelos lineares, em função dos níveis de nitrogênio, demonstrando que haveria resposta a níveis mais elevados que os utilizados no experimento ( Figura 14).

No segundo corte, houve interação tripla entre os cultivares, as doses de nitrogênio e as doses de magnésio utilizadas. Nos cultivares Colonião e Vencedor, em qualquer dose de magnésio e no cultivar Tanzânia-1 na dose de magnésio de $4,8 \mathrm{mg} \mathrm{L}^{-1}$, os aumentos na concentração de nitrogênio foram lineares em função das doses de nitrogênio na solução. No cultivar Tanzânia-1, na dose de magnésio de $48 \mathrm{mg} \mathrm{L}^{-1}$ houve um ajuste a um modelo quadrático (Figura 15).

Os teores encontrados neste experimento foram mais elevados que os encontrados por Werner et al. (1967); Ferrari Neto (1991), mas foram semelhantes aos encontrados por Santos et al. (1995) na dose de nitrogênio de 378 $\mathrm{mg} \mathrm{L}^{-1}$.

A concentração de nitrogênio nas folhas novas, em função das doses de magnésio, somente não variou significativamente na dose de nitrogênio de $42 \mathrm{mg}$ $\mathrm{L}^{-1}$ ( Tabela 8). Na dose de nitrogênio de $210 \mathrm{mg} \mathrm{L}^{-1}$ a concentração deste 

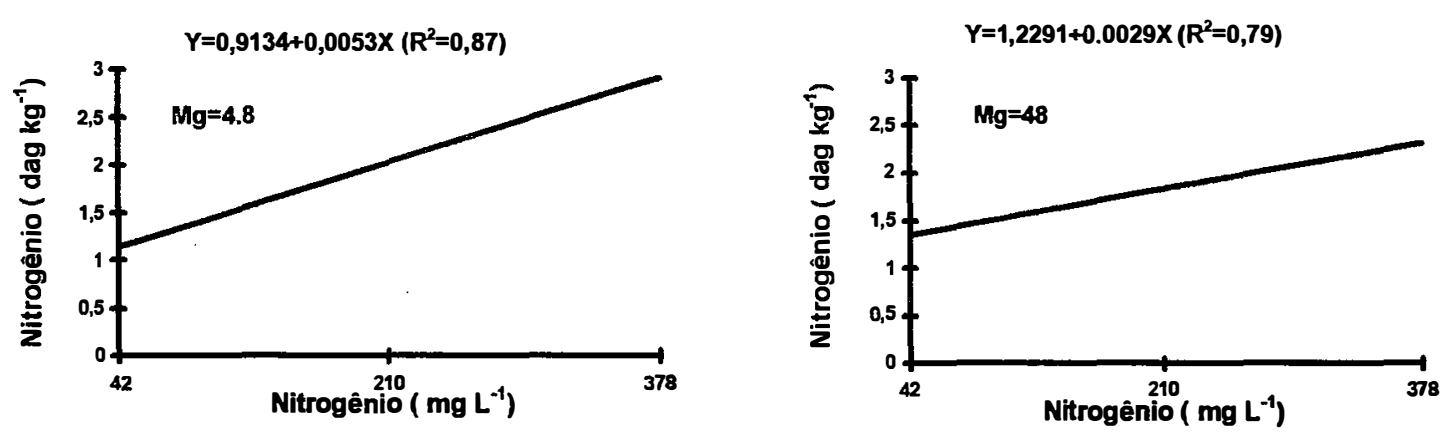

Figura 14. Concentração de nitrogênio na parte aérea média, no primeiro período, médis dos cultivares Colonião, Tanzânia-1 e Vencedor de Panicum maximum, em função das doses de nitrogênio.

nutriente foi mais elevada quando a dose de magnésio estava em $4,8 \mathrm{mg} \mathrm{L}^{-1}$, porém na dose mais elevada de nitrogênio ocorreu o contrário.

No segundo corte, os cultivares não apresentaram diferenças entre si nas doses de nitrogênio de 42 e $210 \mathrm{mg} \mathrm{L}^{-1}$, porém quando esta dose foi elevada para $378 \mathrm{mg} \mathrm{L}^{-1}$, o cultivar Vencedor apresentou a maior concentração de nitrogênio quando o magnésio estava em $48 \mathrm{mg} \mathrm{L}^{-1}$ e a menor quando era $4,8 \mathrm{mg} \mathrm{L}^{1}$ (Tabela 9).

Analisando a variação na concentração de nitrogênio nas folhas novas dos capins, em função das doses de magnésio, dentro das doses de nitrogênio na solução, pode-se notar que nas doses de nitrogênio de 42 e $210 \mathrm{mg} \mathrm{L}^{-1}$ os cultivares não apresentaram diferenças significativas (Figura 16). Quando o nitrogênio foi fornecido na sua dose mais elevada ( $378 \mathrm{mg} \mathrm{L}^{-1}$ ) os cultivares Colonião e Tanzânia-1 apresentaram diferenças quanto as doses de magnésio, com concentrações de nitrogênio mais altas quando o magnésio era fornecido na dose de $4,8 \mathrm{mg} \mathrm{L}^{-1}$. 


\section{COLONIÃO}
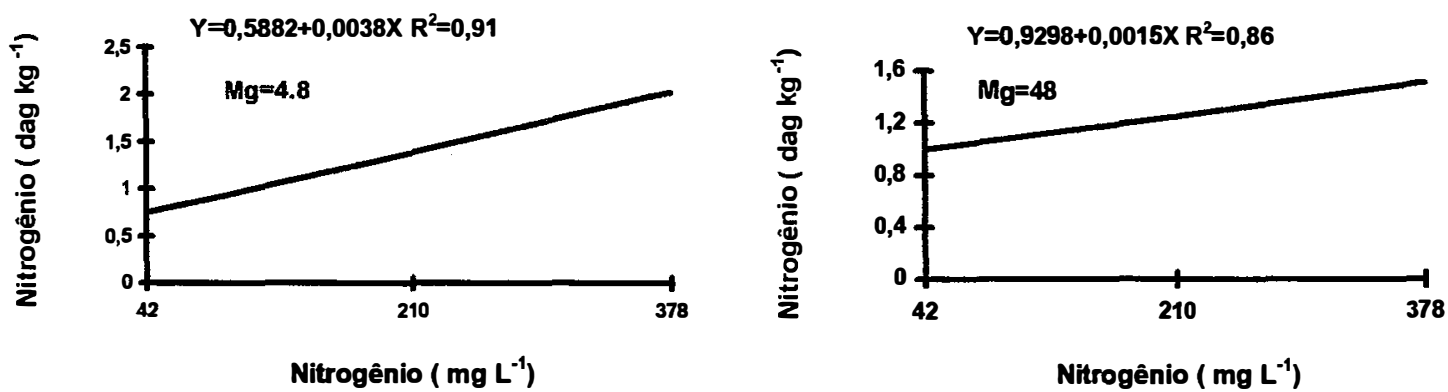

TANZÂNIA-1
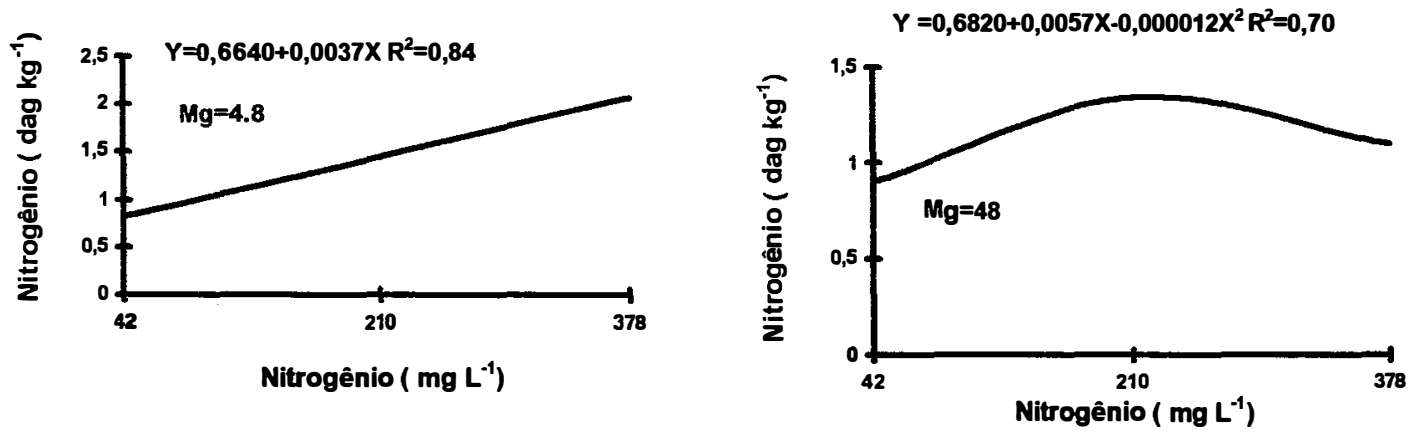

\section{VENCEDOR}
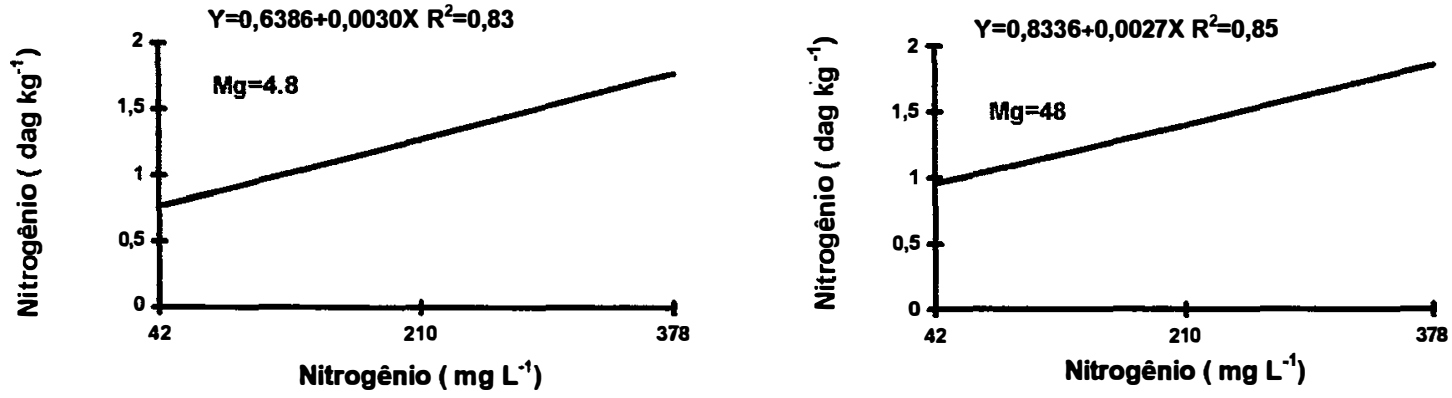

Figura 15. Concentração de nitrogênio nas folhas novas, no segundo período de crescimento, dos cultivares Colonião, Tanzânia-1 e Vencedor de Panicum maximum Jacq, em função das doses de nitrogênio, dentro das doses de magnésio. 
Tabela 8. Concentração de nitrogênio, em dag $\mathrm{kg}^{-1}$, em função das doses de nitrogênio empregadas, dentro das doses de magnésio.

\begin{tabular}{|c|c|c|}
\hline $\begin{array}{c}\mathbf{N} \\
\mathbf{m g ~ L}^{-1}\end{array}$ & $\begin{array}{c}\mathbf{M g}=4,8 \\
\mathbf{m g ~ L}^{-1}\end{array}$ & $\begin{array}{c}\mathbf{M g}=48 \\
\mathbf{m g ~ L}^{-1}\end{array}$ \\
\hline 42 & $1,23 \mathrm{a}$ & $1,30 \mathrm{a}$ \\
\hline 210 & $1,84 \mathrm{~b}$ & $1,94 \mathrm{a}$ \\
\hline 378 & $3,00 \mathrm{a}$ & $2,26 \mathrm{~b}$ \\
\hline
\end{tabular}

Letras diferentes em cada linha indicam diferença significativa ao nível de $5 \%$ de probabilidade

Tabela 9. Concentração de nitrogênio no segundo corte em três cultivares de Panicum em função das doses de nitrogênio, dentro das doses de magnésio empregadas.

\begin{tabular}{|c|c|c|c|}
\hline $\mathbf{N}\left(\mathbf{m g ~ L}^{-1}\right)$ & Colonião & Tanzânia & Vencedor \\
\hline & \multicolumn{3}{|c|}{$\mathbf{M g = 4 , 8} \mathbf{~ m g ~ L}^{-1}$} \\
\hline $\mathbf{4 2}$ & $0,84 \mathrm{a}$ & $0,88 \mathrm{a}$ & $0,75 \mathrm{a}$ \\
\hline $\mathbf{2 1 0}$ & $1,20 \mathrm{a}$ & $1,34 \mathrm{a}$ & $1,30 \mathrm{a}$ \\
\hline $\mathbf{3 7 8}$ & $2,12 \mathrm{a}$ & $2,13 \mathrm{a}$ & $1,76 \mathrm{~b}$ \\
\hline & & \multicolumn{3}{|c|}{$\mathbf{M g}=\mathbf{4 8} \mathbf{~ m g ~ L}^{-1}$} \\
\hline $\mathbf{4 2}$ & $0,91 \mathrm{a}$ & $0,90 \mathrm{a}$ & $0,97 \mathrm{a}$ \\
\hline $\mathbf{2 1 0}$ & $1,42 \mathrm{a}$ & $1,35 \mathrm{a}$ & $1,34 \mathrm{a}$ \\
\hline $\mathbf{3 7 8}$ & $1,43 \mathrm{a}$ & $1,10 \mathrm{a}$ & $1,88 \mathrm{~b}$ \\
\hline
\end{tabular}

Letras diferentes em cada linha indicam diferença significativa ao nível de $5 \%$ de probabilidade 

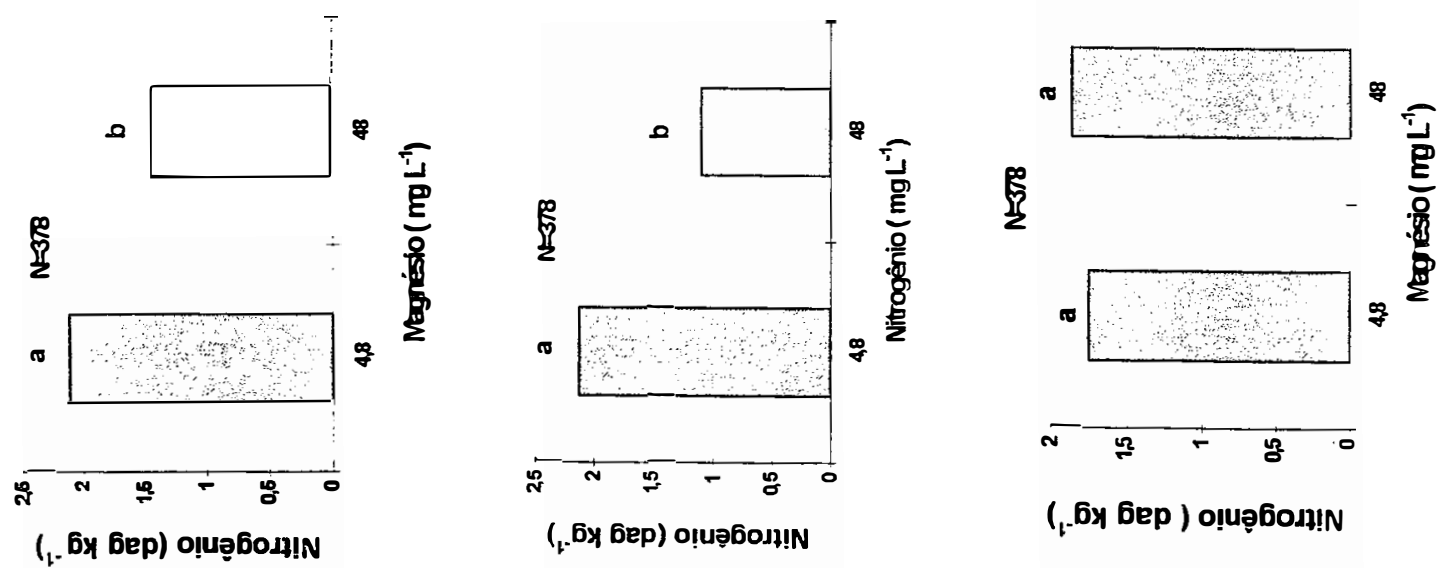

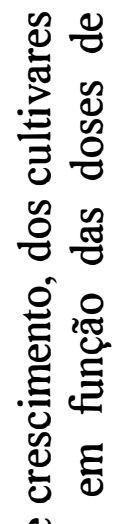

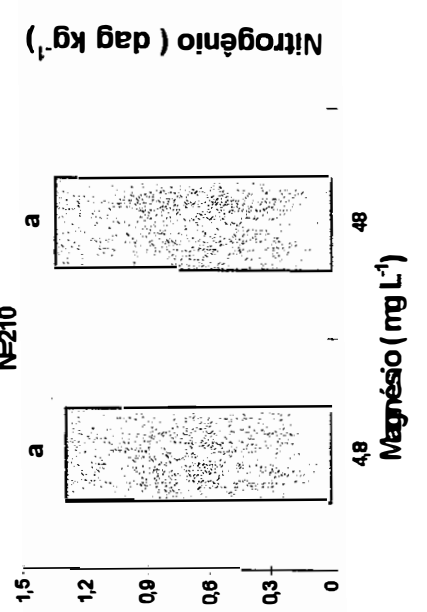

윰
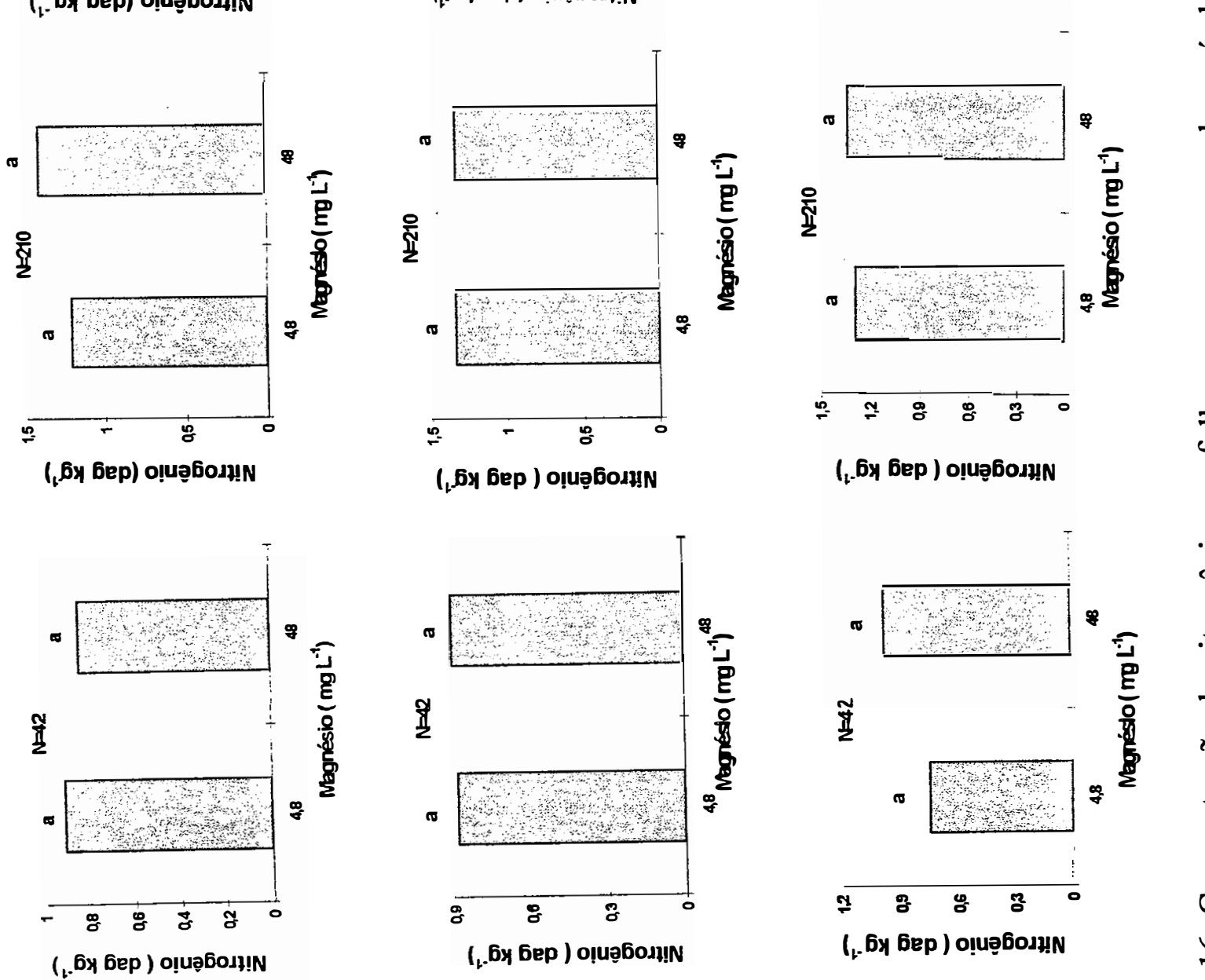

员

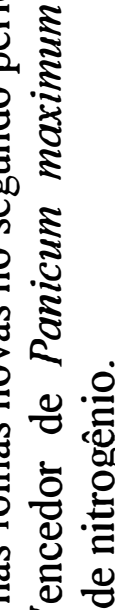

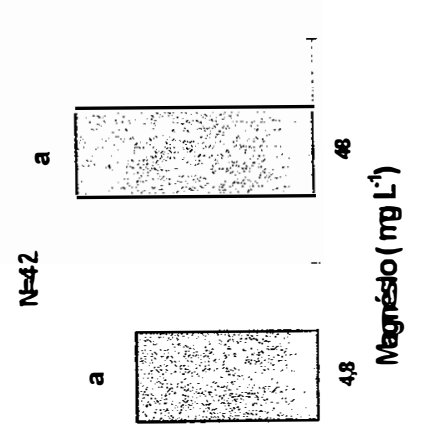

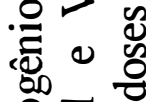

인

.

융ำ

틀

खण्ष

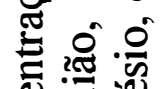

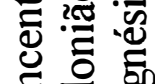

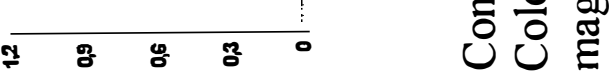

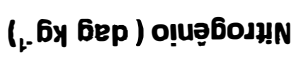

1

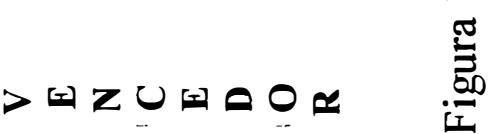




\subsubsection{Folhas velhas}

Os dados referentes as folhas velhas apresentaram efeito significativo para as doses de nitrogênio em solução nutritiva, ajustando-se, tanto no primeiro como no segundo crescimento das plantas, a modelos lineares de regressão ( Figura 17).

Houve um aumento na concentração de nitrogênio nas folhas velhas dos capins, em função do aumento do nitrogênio na solução. Não ocorreram significâncias para as variações entre cultivares ou entre doses de magnésio na solução.

1 CORTE

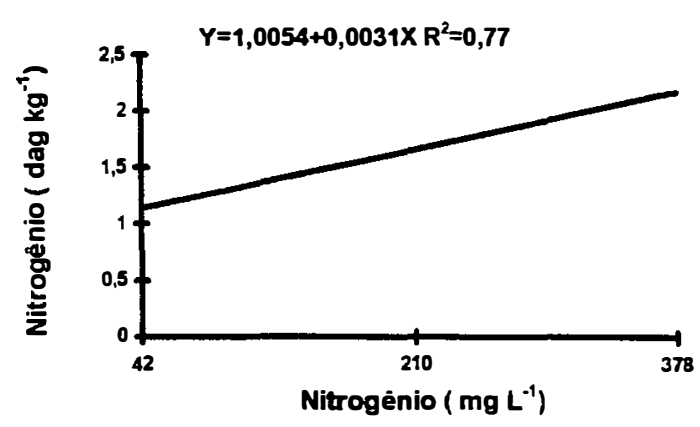

\section{CORTE}

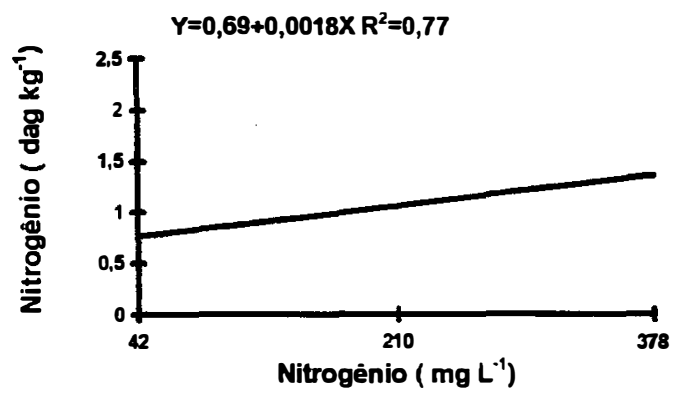

Figura 17. Concentração de nitrogênio nas folhas velhas, no primeiro e segundo períodos de crescimento, na média dos cultivares Colonião, Tanzânia-1 e Vencedor de Panicum maximum Jacq, em função das doses de nitrogênio. 


\subsubsection{Colmos mais bainhas}

Em termos da concentração de nitrogênio nos colmos mais bainhas das forrageiras, no primeiro crescimento houve significância para a interação entre doses de nitrogênio e doses de magnésio, e entre doses de nitrogênio e cultivares. Os cultivares Colonião e Tanzânia-1 apresentaram aumentos lineares na concentração de nitrogênio nos colmos mais bainhas, em função das doses de nitrogênio. Essa concentração de nitrogênio aumentou conforme uma equação do segundo grau no Vencedor ( Figura 18).

Com relação às doses de magnésio, o aumento na concentração de nitrogênio foi linear em qualquer das doses empregadas. para os colmos mais bainhas ( Figura 19).

No segundo crescimento a concentração de nitrogènio nos colmos mais bainhas foi significativamente afetada pelas doses de nitrogênio variando de forma quadrática ( Figura 20). 

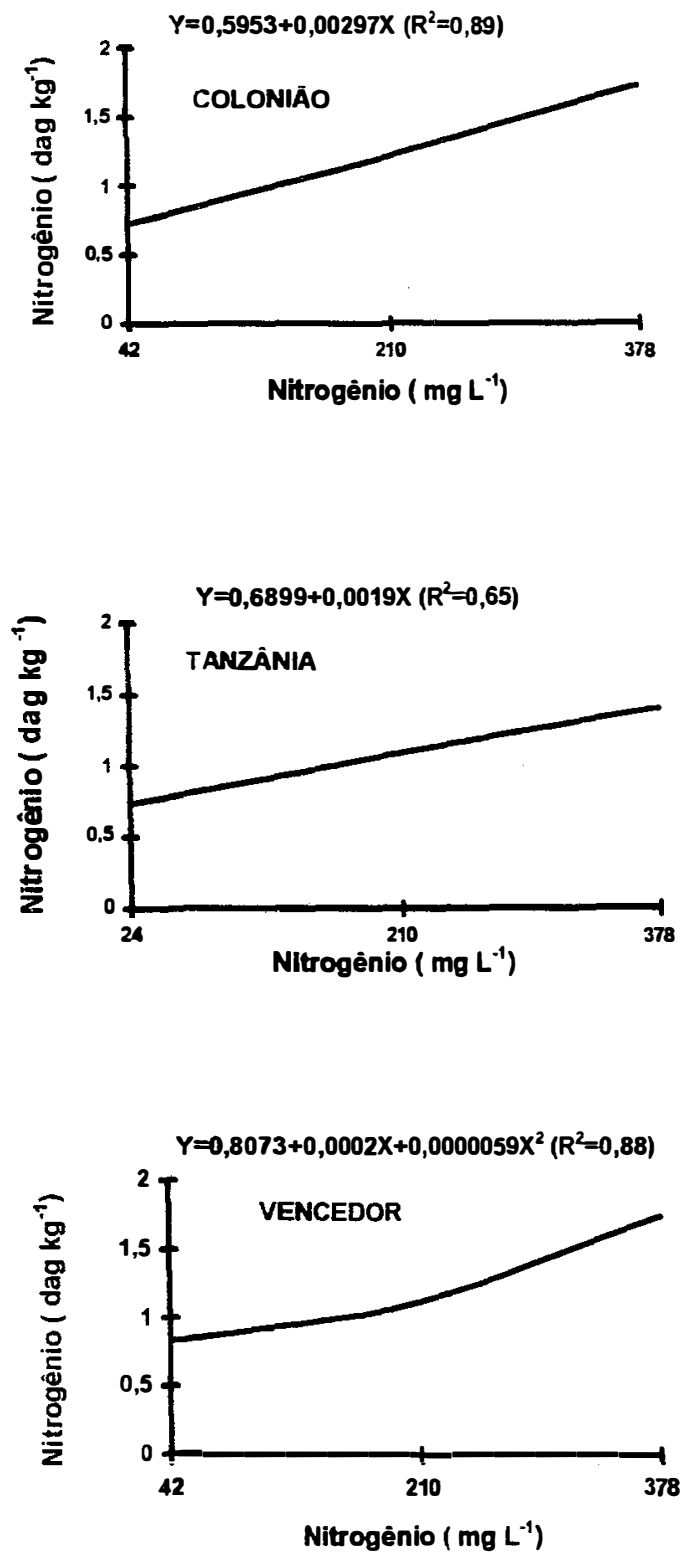

Figura 18. Concentração de nitrogênio nos colmos+bainhas, no primeiro período de crescimento, dos cultivares Colonião, Tanzânia-1 e Vencedor de Panicum maximum, em função das doses de nitrogênio. 

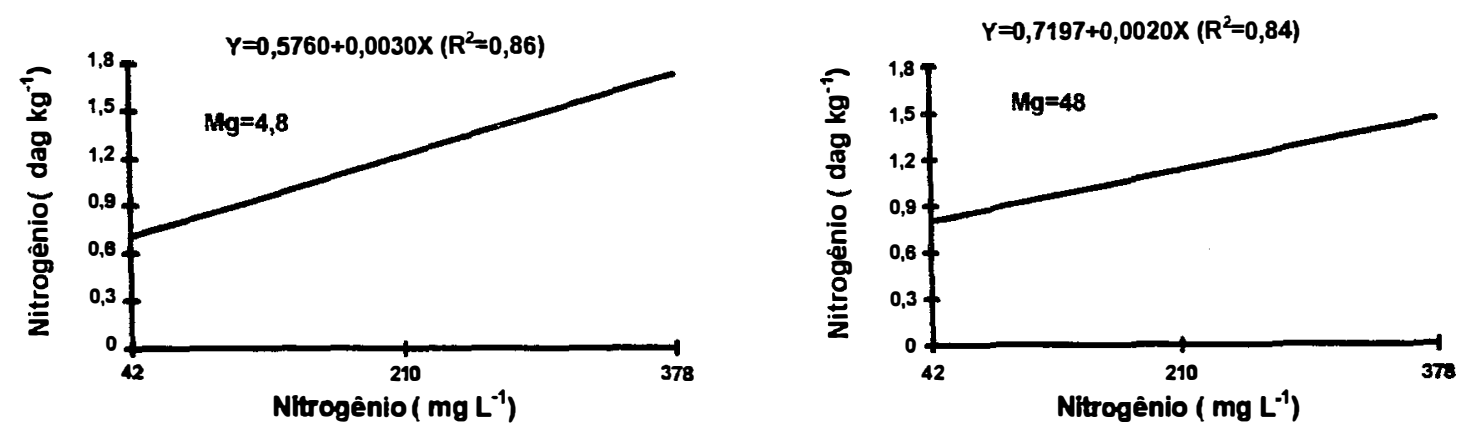

Figura 19. Concentração de nitrogênio nos colmos mais bainhas, no primeiro período de crescimento, na média dos cultivares Colonião, Tanzânia-1 e Vencedor de Panicum maximum, em função das doses de nitrogênio.

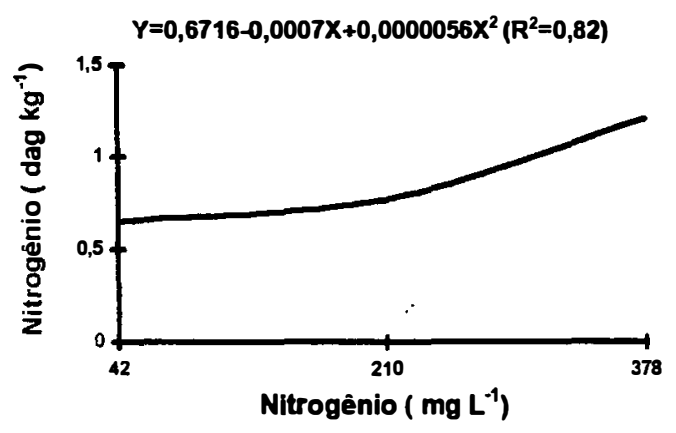

Figura 20. Concentração de nitrogênio nos colmos mais bainhas, no segundo período de crescimento, na média dos cultivares Colonião, Tanzânia-1 e Vencedor de Panicum maximum Jacq, em função das doses de nitrogênio. 


\subsection{Concentração de magnésio nos tecidos vegetais}

Nos dois períodos de crescimento a concentração de magnésio em todos os componentes da parte aérea, exceto para as folhas velhas no primeiro crescimento, mostrou interação significativa entre doses de nitrogênio e doses de magnésio fornecidas na solução nutritiva.

\subsubsection{Folhas novas}

A concentração de magnésio nessa parte da planta, nos dois períodos de crescimento, obedeceu a modelos quadráticos de regressão, em função das doses de nitrogênio, em qualquer dose de magnésio utilizada (Figuras 21 e 22).

Nos dois períodos de crescimento a concentração de magnésio nas folhas novas, quando a dose de magnésio era de $4,8 \mathrm{mg} \mathrm{L}^{-1}$, foi mais elevada na dose de nitrogênio de $42 \mathrm{mg} \mathrm{L}^{-1}$, devido possivelmente a um menor desenvolvimento da planta.
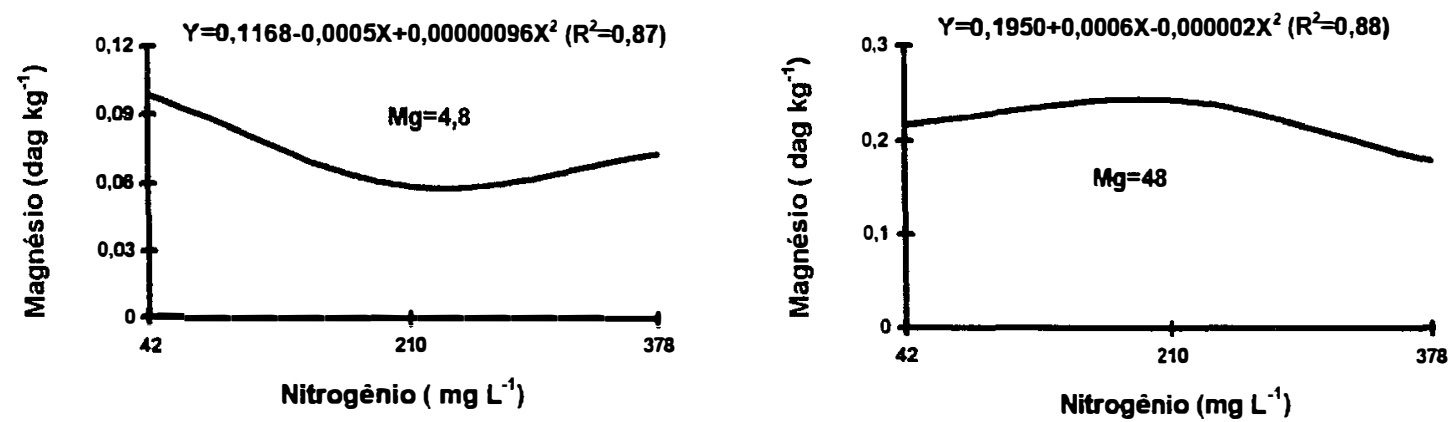

Figura 21. Concentração de magnésio nas folhas novas, no primeiro período de crescimento, na média dos cultivares Colonião, Tanzânia-1 e Vencedor de Panicum maximum Jacq, em função das doses de nitrogênio. 
Analisando o efeito das doses de magnésio, em ambos os cortes dos capins, foi possível verificar que em todas as doses de nitrogênio fornecidas na solução ( 42,210 e $\left.378 \mathrm{mg} \mathrm{L}^{-1}\right)$ a concentração de magnésio variou significativamente. Houve sempre um aumento na concentração de magnésio, nas folhas novas, com o aumento da dose de magnésio na solução nutritiva (Figuras 23 e 24). Esses teores estiveram abaixo dos encontrados por Gomide et al. (1986).
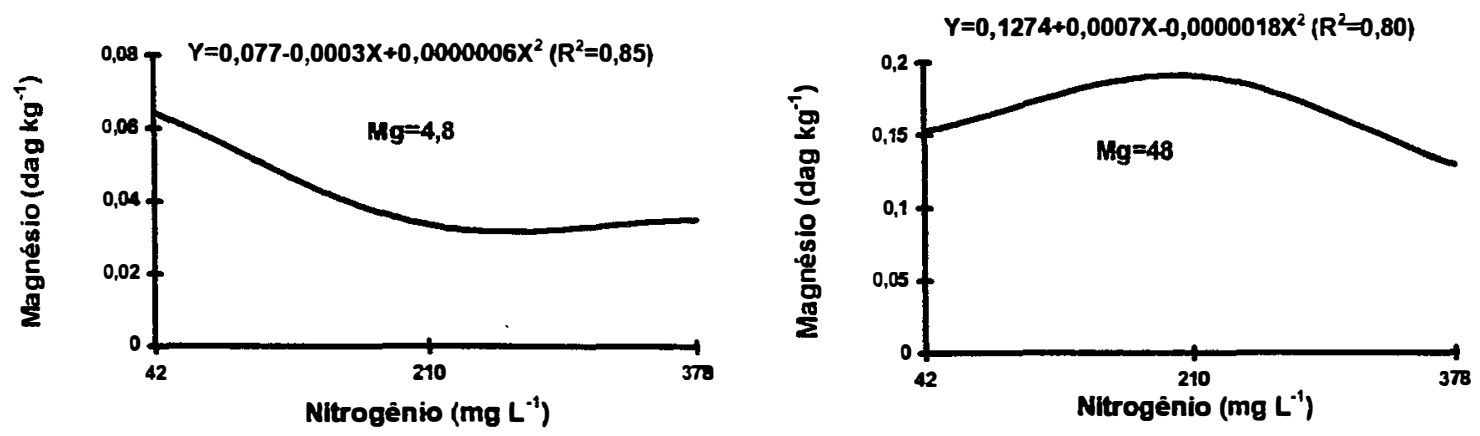

Figura 22. Concentração de magnésio nas folhas novas, no segundo período de crescimento. na média dos cultivares Colonião, Tanzânia-1 e Vencedor de Panicum maximum Jacq, em função das doses de nitrogênio. 

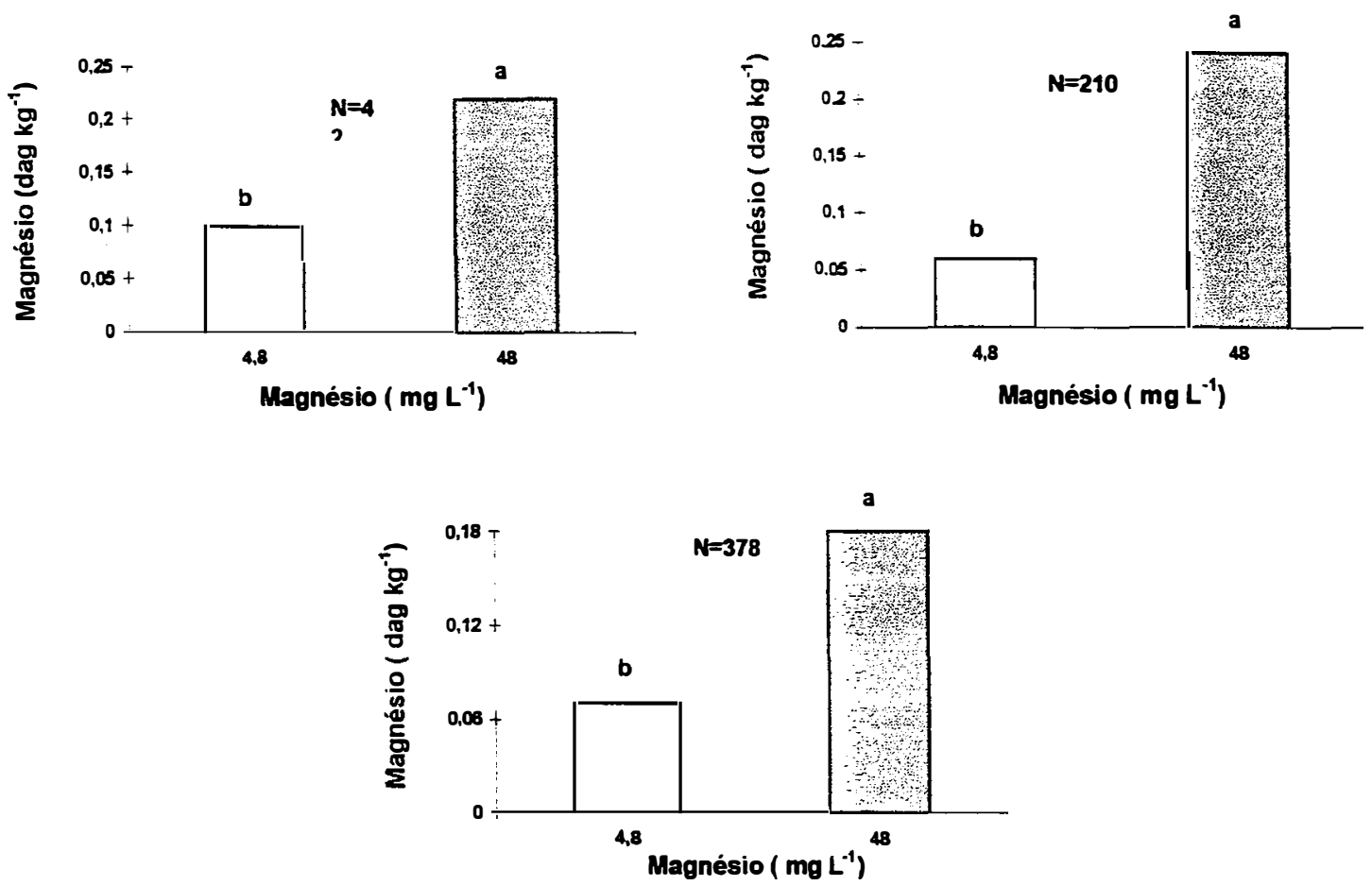

Figura 23. Concentração de magnésio nas folhas novas, no primeiro período de crescimento, na média dos cultivares Colonião, Tanzânia-1 e Vencedor de Panicum maximum Jacq, em função das doses de magnésio. 

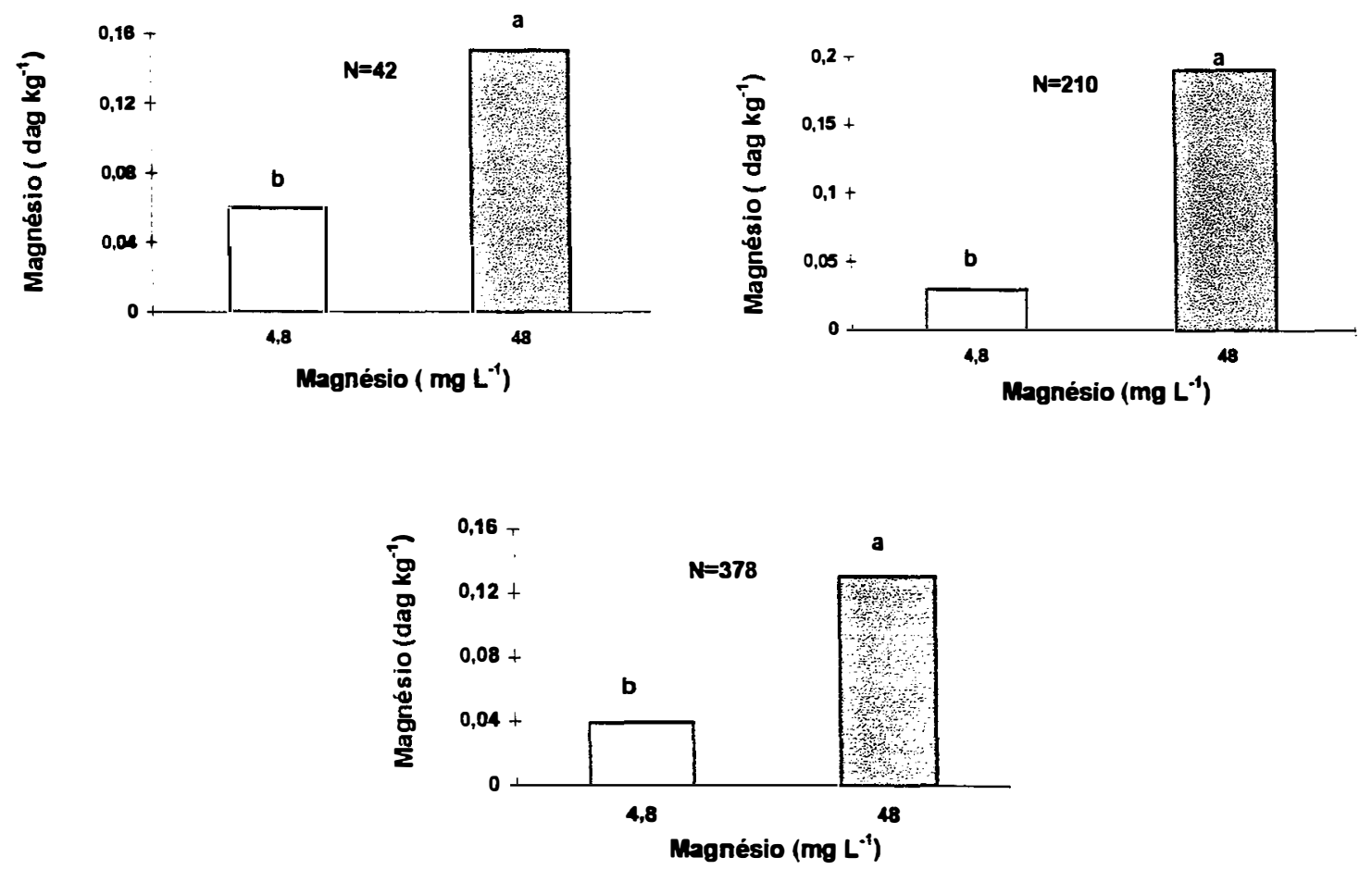

Figura 24. Concentração de magnésio nas folhas novas, no segundo período de crescimento, na média dos cultivares Colonião, Tanzânia-1 e Vencedor de Panicum maximum, em função das doses de magnésio.

\subsubsection{Folhas velhas}

No primeiro período de crescimento as folhas velhas não mostraram significância para nenhuma das variáveis estudadas. No segundo período de crescimento a concentração de magnésio nas folhas velhas obedeceu a modelos quadráticos de regressão em função das doses de nitrogênio, dentro das doses de magnésio na solução (Figura 25 ). 

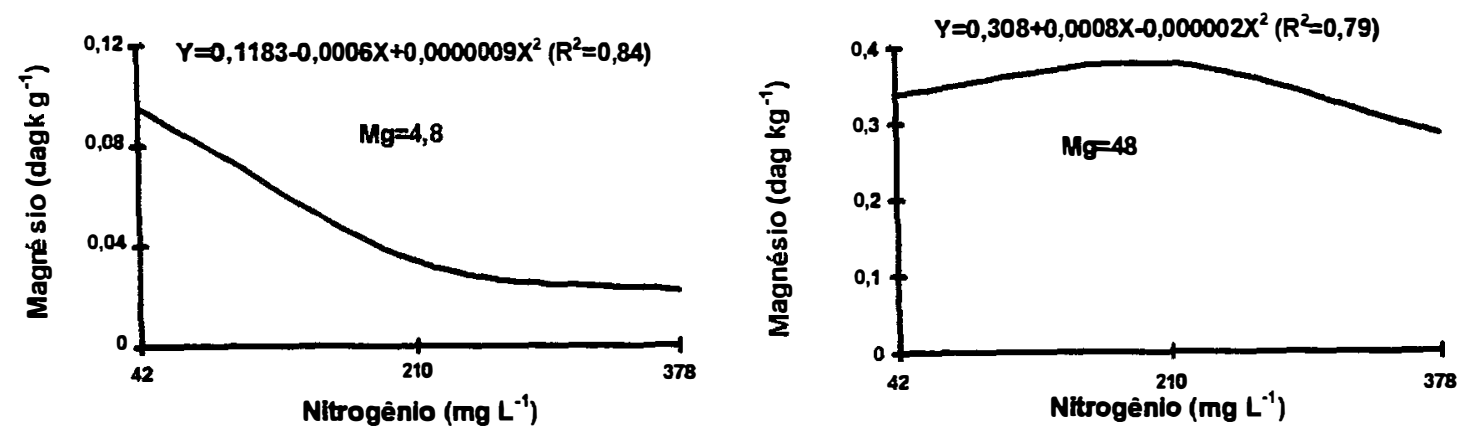

Figura 25. Concentração de magnésio nas folhas velhas, no segundo período de crescimento, na média dos cultivares Colonião, Tanzânia-1 e Vencedor de Panicum maximum Jacq, em função das doses de nitrogênio, dentro das doses de magnésio.

Em qualquer dose de nitrogênio utilizada a concentração de magnésio nas folhas velhas foi estatisticamente diferente quando houve variação nas doses de magnésio em solução. sendo sempre superior na dose de $48 \mathrm{mg} \mathrm{L}^{-1}$ (Figura 26).

$\mathrm{O}$ teor deste elemento nas folhas velhas foi superior aos encontrados por

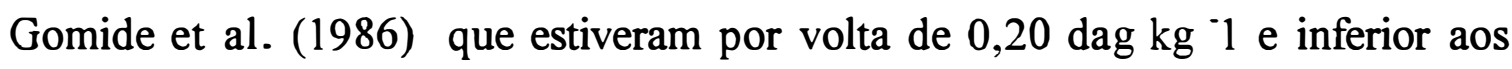
obtidos por Premazzi (1991). 

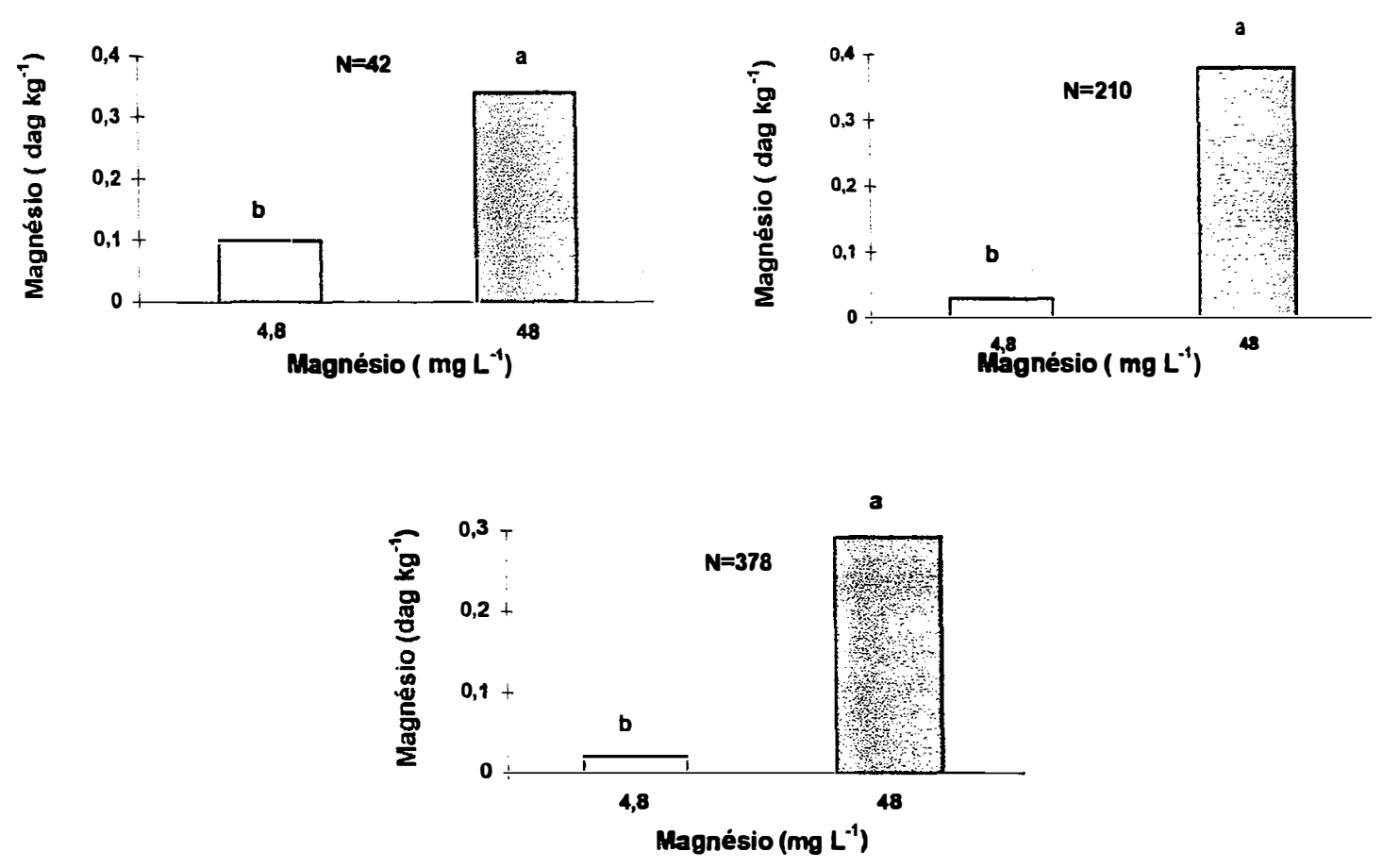

Figura 26. Concentração de magnésio nas folhas novas, no segundo período de crescimento, na média dos cultivares Colonião, Tanzânia-1 e Vencedor de Panicum maximum Jacq, em função das doses de magnésio, dentro das doses de nitrogênio.

\subsubsection{Colmos mais bainhas}

Os resultados de concentração de magnésio nos colmos mais bainhas ajustou-se à modelos quadráticos de regressão, tanto no primeiro como no segundo período de crescimento e em ambas as doses de magnésio, quando submetidos as doses de nitrogênio na solução (Figuras 27 e 28). 

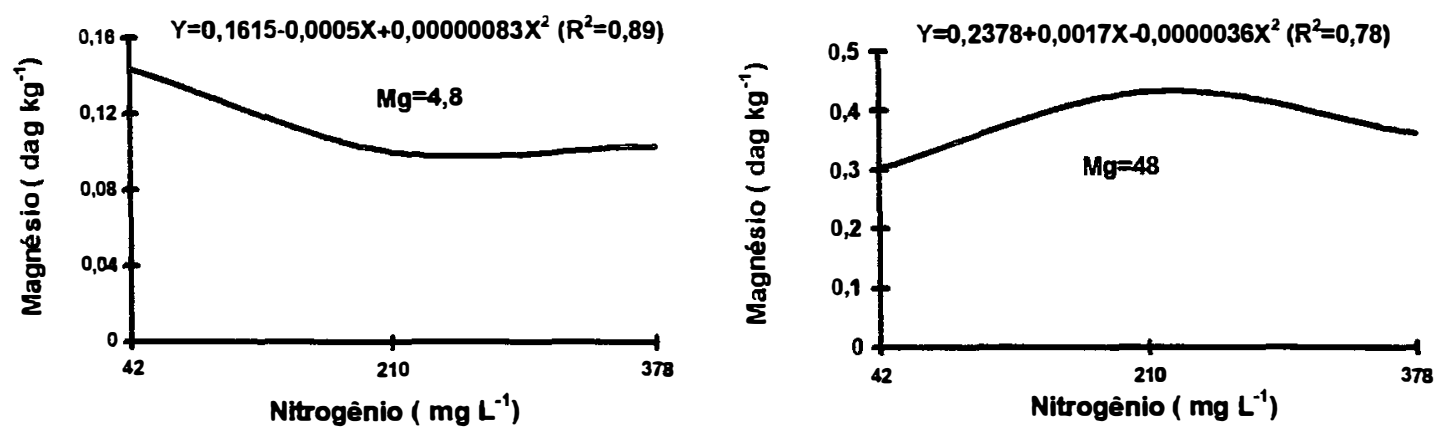

Figura 27. Concentração de magnésio nos colmos+bainhas, no primeiro período de crescimento, na média dos cultivares Colonião, Tanzânia-1 e Vencedor de Panicum maximum Jacq, em função das doses de nitrogênio, dentro das doses de magnésio.
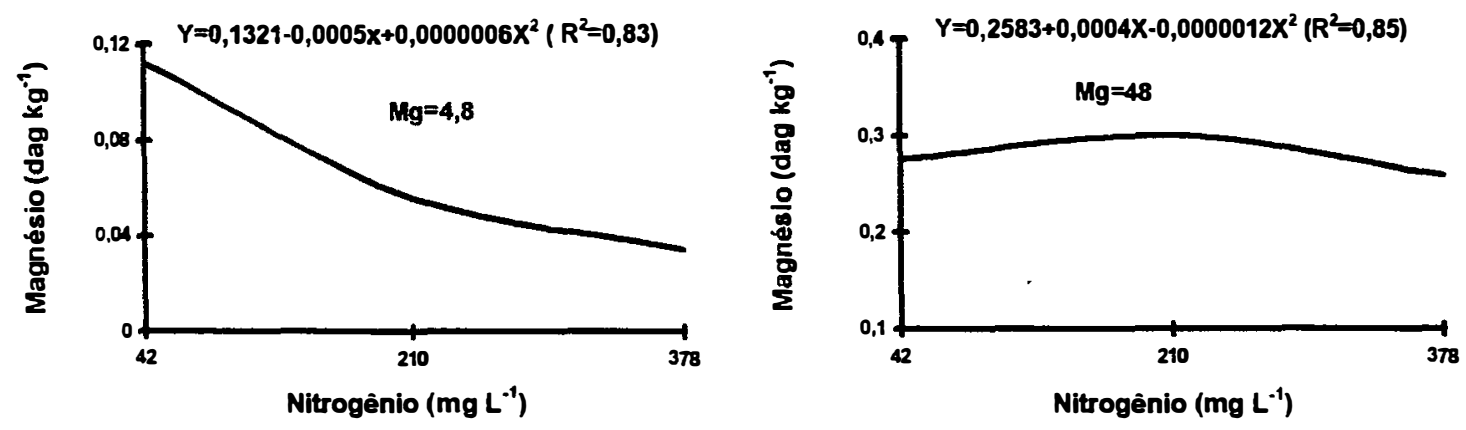

Figura 28. Concentração de magnésio nos colmos+bainhas, no segundo período, na média dos cultivares Colonião, Tanzânia e Vencedor de Panicum maximum Jacq, em função das doses de magnésio.

Em ambos os períodos de crescimento, a concentração de magnésio nos colmos mais bainhas, em qualquer das doses de nitrogênio utilizada, foi mais elevada quando o magnésio foi fornecido na dose de $48 \mathrm{mg} \mathrm{L}^{-1}$, demonstrando um aumento na concentração em função do fornecimento na solução nutritiva ( Figuras 29 e 30). 

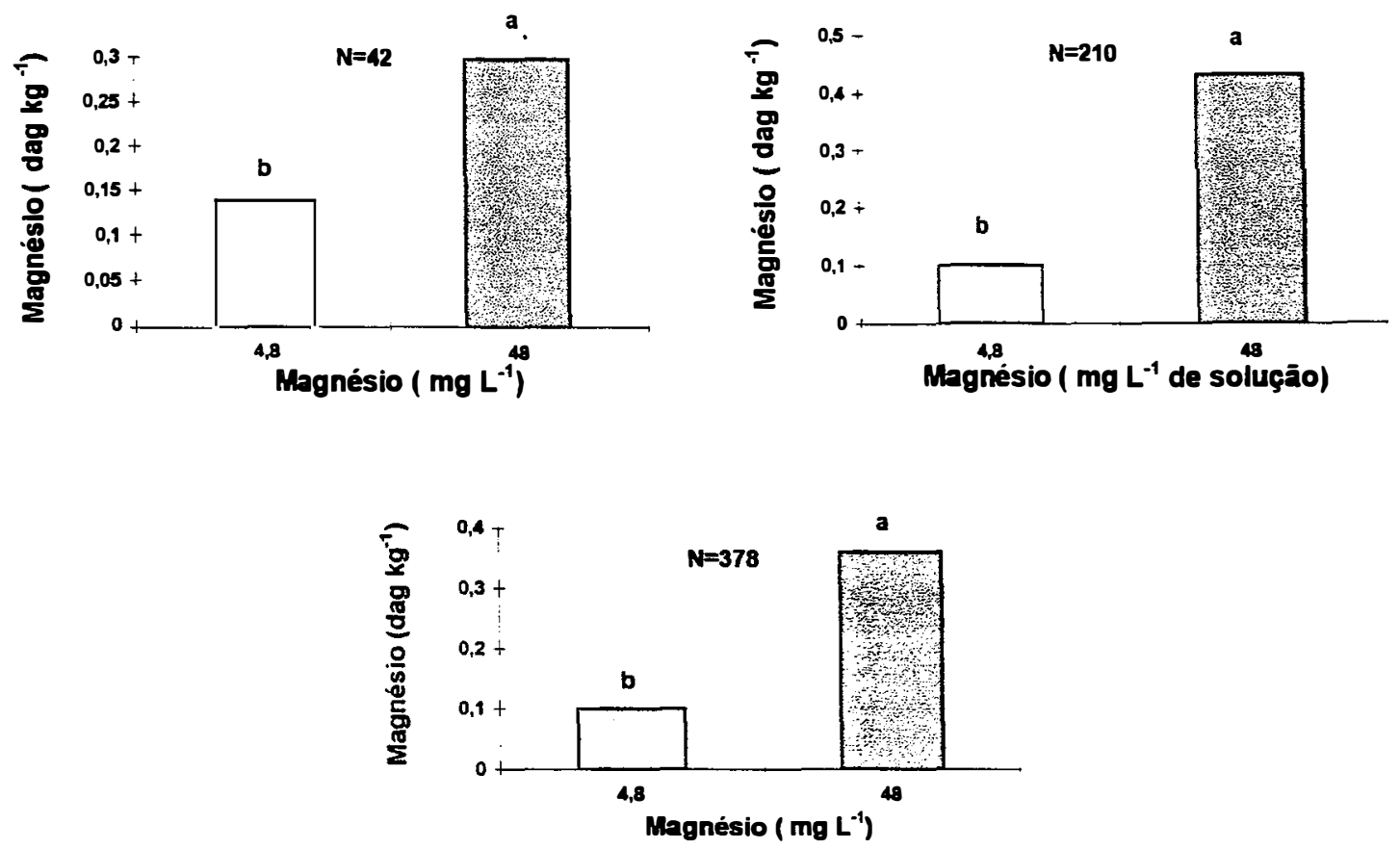

Figura 29. Concentração de magnésio nos colmos mais bainhas, no primeiro período de crescimento, na média dos cultivares Colonião, Tanzânia-1 e Vencedor de Panicum maximum Jacq, em função das doses de magnésio, dentro das doses de nitrogênio. 

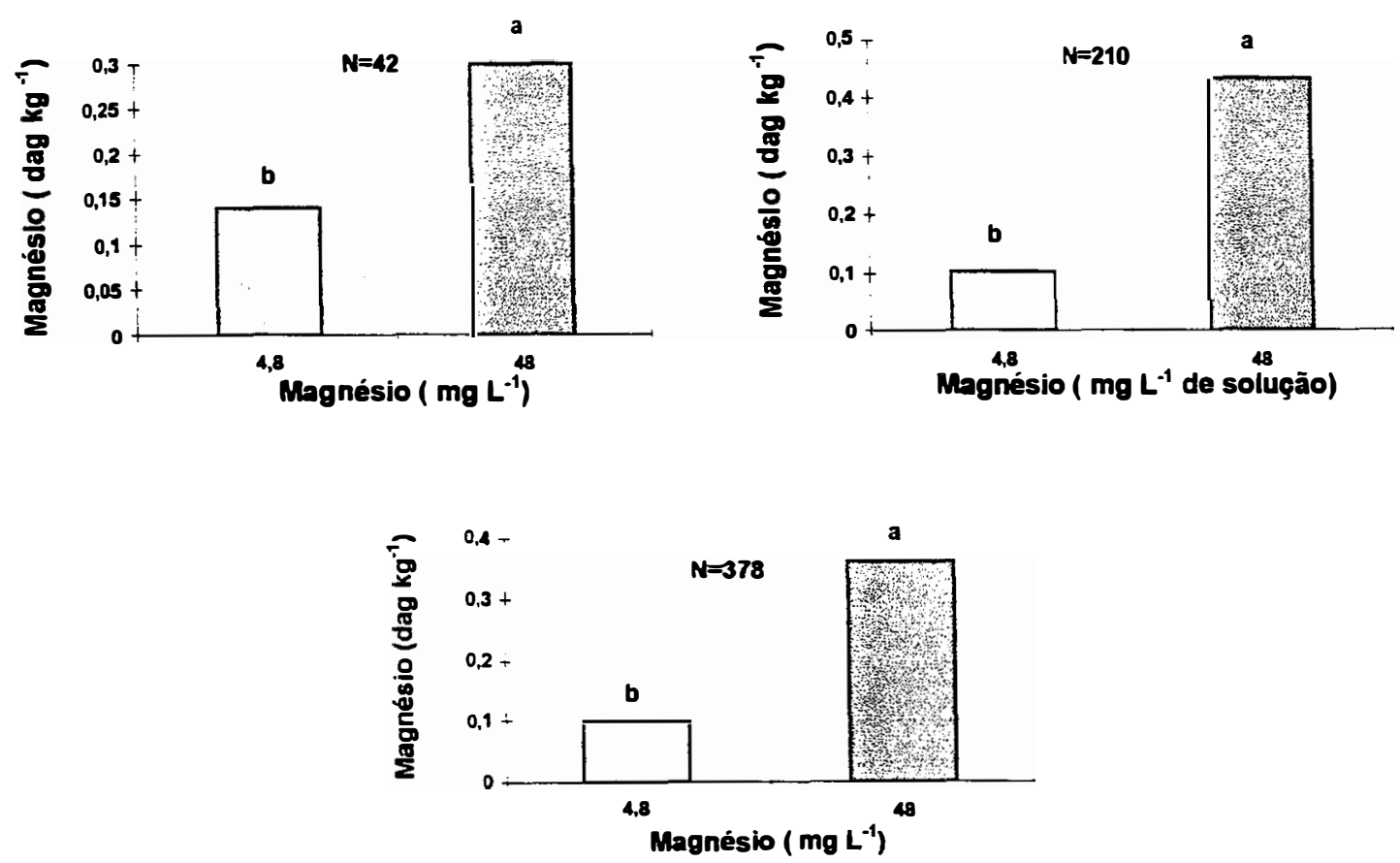

Figura 30. Concentração de magnésio nos colmos mais bainhas, no segundo periodo de crescimento, na média dos cultivares Colonião, Tanzânia-1 e Vencedor de Panicum maximum Jacq, em função das doses de magnésio, dentro das doses de nitrogênio. 


\section{CONCLUSÕES}

Nas condições em que foi desenvolvido o presente trabalho, os resultados obtidos permitem apresentar as seguintes conclusões:

- O aumento nas doses de nitrogênio na solução nutritiva proporcionou aumentos na produção de matéria seca da parte aérea, na produção de matéria seca das raízes e no perfilhamento dos cultivares Colonião, Tanzânia-1 e Vencedor de Panicum maximum.

- Somente quando o nitrogênio foi fornecido em dose alta os cultivares de Panicum maximum apresentaram diferenças na produção de matéria seca da parte aérea e das raizes, com as doses de magnésio utilizadas.

- A atividade da enzima redutase do nitrato nas folhas de Panicum maximum aumentou em função das doses de nitrogênio, independente da dose de magnésio utilizada.

- As doses de nitrogênio empregadas interferiram na atividade da enzima glutamina sintetase. Os cultivares diferiram entre si quando se utilizou dose elevada de nitrogênio na solução nutritiva. 
- A concentração de nitrogênio nas folhas novas, nas folhas velhas e nos colmos mais bainhas dos cultivares de Panicum moximum aumentou em função das doses de nitrogênio na solução nutritiva.

- A concentração de magnésio nas folhas novas, nas folhas velhas e nos colmos mais bainhas foi afetada tanto pelas doses de nitrogênio como pelas de magnésio na solução. 


\section{REFERÊNCIAS BIBLIOGRÁFICAS}

ABREU, J.B.R. Níveis de nitrogênio e proporção de nitrato e amônio afetando produção, atividade da redutase do nitrato e composição de três gramíneas forrageiras. Piracicaba. 1994. 109p. Dissertação (M. S.)- Escola Superior de Agricultura "Luiz de Queiroz", Universidade de São Paulo.

ALVIM, M. J.; BOTREL, M. A.; VERNEQUE, R. S.; SALVATI, J. A. Aplicação de nitrogênio em acessos de Brachiaria. 1. Efeito sobre a produção de matéria seca. Pasturas Tropicales, v.12, p.2-6,1990.

ANDRADE, S.R.M. Efeito da proporção $\mathrm{NH}_{4}{ }^{+} / \mathrm{NO}_{3}{ }^{-}$na composição da fração nitrogenada e na atividade das enzimas de redução e assimilação de nitrogênio em plantas de capim-colonião (Panicum maximum Jacq). Viçosa. 1994. 49p. Dissertação (M. S.)- Universidade Federal de Viçosa.

ANGHINONI, I.: MAGALHÃES. J.R.; BARBER, S.A. Enzyme activity, nitrogen uptake and corn growth as affected by ammonium concentration in soil solution. Journal of Plant Nutrition, v.11, p.131-144,1988. 
ARONOVICH. S. O capim colonião e outros cultivares de Panicum maximum Jacq.:introdução e evolução do uso no Brasil. In: SIMPÓSIO SOBRE MANEJO DA PASTAGEM, 12., Piracicaba, 1995 . Anais. Piracicaba: FEALQ, 1995 . p.1-20.

BEEVERS.L.; HAGEMAN,R.H. Nitrate reduction in higher plants. Annual Review of Plant Physiology, v. 20, p.495-522, 1969.

BENDIX, M.E.S.; FERNANDES, M.S.; ROSSIELO, R.O.P. Aspectos de la nutrición nitrogenada de Paspalum notatum Flugge, en respuesta a fuentes de nitrógeno e inhibictión de nitrificación. Turrialba, v. 32.p.33-41,1982.

BOWERMAN,A.; GOODMAN,P.J. Variation in nitrate reductase activity in Lolium. Annals of Botany,v.35, p.354-366, 1971.

CAMPBELL, W.H. Nitrate reductase and its role in nitrate assimilation in plants. Physiologia Plantarum,v. 74, p.214-219,1988.

CARRIEL, J.M.; PEDREIRA, J.V.S.; MATTOS, H.B. Estimativa da ocorrência dos principais capins no Estado de São Paulo. Zootecnia, v.17, p.5-25, 1979.

CHANDLER. J. Intensive grassland management in Puerto Rico. Revista da Sociedade Brasileira de Zootecnia, v.2, p.173-215,1973. 
COLOZZA, M.T.; SAVASTANO, S.A.L.; WERNER, J.C.; MONTEIRO, F.A. Efeitos da aplicação de gesso e calcário dolomítico em dois solos ácidos cultivados com soja-perene. Boletim de Indústria Animal, v. 40, p.7596, jan./jun. 1983.

CONTIBRASIL- Informe Técnico, 2- outubro 1985, 4p.

CORREAA, A.N.S.; ARONOVICH, S. Influência de queima periódica sobre a vegetação e sobre a fertilidade dos terrenos de pastagens. Revista da Sociedade Brasileira de Zootecnia, v.8. p. 332-346. 1979.

CORSI, M. Adubação nitrogenada das pastagens. In: SIMPÓSIO SOBRE MANEJO DE PASTAGENS, 2., Piracicaba, 1975. Anais. Piracicaba: FEALQ, 1975 - p.112-135.

CORSI, M. Effects of nitrogen rates and harvesting intervals on dry matter production, tillering and quality of the tropical grass Panicum maximum Jacq. Ames, 1984. 125p. Thesis (PhD)- Ohio State University.

CORSI, M.; BALSALOBRE, M. A.; SANTOS, P.M.; SILVA, S.C. da. Bases para o estabelecimento do manejo de pastagens de braquiária. In: SIMPÓSIO SOBRE MANEJO DE PASTAGENS, 11., Piracicaba, 1975. Anais. Piracicaba: FEALQ, 1994. p.249-266.

CRESPO, G. Variation in the response of tropical pastures to nitrogenous fertilizers throughout the year. 3. Guinea grass (Panicum maximum Jacq.) with irrigation. Cuban Journal of Agricultural Science. v. 20. p. 73-81, 1986. 
CULLIMORE, J. V.; BENNETT, H. J. The molecular biology and biochemistry of plant glutamine synthetase from root nodules of Phaseolus vulgaris 1 . and other legumes. Journal of Plant Physiology, v.132, p.387-393, 1988.

DEANNE-DRUMMOND, C. E. Biochemical and biophysical aspects of nitrate uptake and its regulation. In: ABROL, Y.P. (Ed.) Nitrogen in higher plants. Somerset: England. Research Studies. 1990. p. 1-37.

DECKARD, E.L.; LAMBERT, R.J.: HAGEMAN, R.H. Nitrate reductase activity in corn leaves as related to yields of grain and grain protein. Crop Science, v. 13, p.343-350,1973.

DIAS FILHO, M.B. Espécies forrageiras e estabelecimento de pastagens na Amazônia. Belém: EMBRAPA, CPATU, 1987. 49p. (Documento, 46).

ECK, H.V.; HAGEMAN, R.H. Nitrate reductase activity sudangrass cultivars. Crop Science,v. 14, p.283-287,1974.

EILRICH, G.L.; HAGEMAN, R.H. Nitrate reductase activity and its relationship to accumulation of vegetative and grain nitrogen in wheat (Triticum aestivum L.). Crop Science, v.13, p.59-66,1973.

ELLIOTT, W.H. Isolation of glutamine synthetase and glutamontransferase from green peas. The Journal of Biological Chemistry, v.201, p. 661-673, 1953. 
FAVORETTO, V.; RODRIGUES, L.R.A.; TUPINAMBÁ, L.F. Estudo do nitrogênio na produção e composição bromatológica do capim-colonião e seus aspectos econômicos. Científica, v.9, p. 295-300, 1988.

FERNANDES, M.S.; FREIRE, L.R. Efeitos de nitrogênio nítrico aplicado ao solo na atividade da nitrato redutase e acumulação de $\mathrm{N}$-solúvel em Brachiaria sp. Turrialba,v. 26, p.268-273,1976.

FERNANDES, M.S. \& FREIRE, L.R. Efeitos da interação de $\mathrm{N}-\mathrm{NO}_{3}$ e $\mathrm{NH}_{4}$ na atividade da nitrato redutase e acumulação de N-proteico com Brachiaria sp. Turrialba, v.28, p.187-191,1978.

FERNANDES, M.S.; ROSSIELO R.O.P. Aspectos do metabolismo e utilização do nitrogênio em gramíneas tropicais. In: SIMPÓSIO SOBRE CALAGEM E ADUBAÇÃO DE PASTAGENS, 1., Nova Odessa, 1985. Anais. Piracicaba: POTAFOS, 1986 . p. 93-123.

FERRARI NETO,J. Limitações nutricionais para o colonião (Panicum maximum Jacq) e braquiária (Brachiaria decumbens Stapf) em latossolo da região noroeste do estado do Paraná. Lavras,1991 .126p. Dissertação (M. S.)Escola Superior de Agricultura de Lavras.

GOMIDE, J. A. Aspectos biológicos e econômicos da adubação de pastagens. In: ECOSSISTEMA DE PASTAGENS, l., Jaboticabal, 1989. Anais. Jaboticabal: FUNEP, 1989. p.237-270. 
GOMDE, J. A.; COSTA,G.G. Adubação nitogenada e consorciação de capim-colonião e capim-jaraguá.3 Efeitos de níveis de nitrogênio sobre a composição mineral e digestibilidade da matéria seca das gramíneas. Revista da Sociedade Brasileira de Zootecnia, v.13, p.215- 224,1984.

GOMIDE, J. A.; ZAGO, C.P.; RIBEIRO, A.C.; BRAGA, J.M.; MARTINS, O. Calagem, fontes de fósforo e níveis de fósforo no estabelecimento e produção de capim-colonião (Panicum maximum Jacq) no cerrado. Revista da Sociedade Brasileira de Zootecnia, v.13, p.241-246, 1986.

GUSS, A.; AGOSTINI, J.A.E. Sistema de produção de leite. Vitória: EMCAPA, 1984. 18p. ( Circular Técnica,8).

HUBER, S.C.; HUBER, J.L. Metabolic activators of spinach leaf nitrate reductase: effects on enzymatic actiity and dephosphorylation by endogenous phosphatases. Planta, v. 196, p.180-189,1995.

JANK,L. Potencial do Gênero Panicum. In: SIMPÓSIO BRASILEIRO DE FORRAGEIRAS E PASTAGENS, 1., Campinas, 1994. Anais. Campinas: Colégio Brasileiro de Nutrição Animal, 1994. p. 25-31.

LARA, M.; CULLIMORE, J. V.; LEA, P.L.; MIFLIN, B. J.; JOHNSTON, A.W.B.; LAMB, J.W. Appearance of a novel form of plant glutamine synthetase during nodule development in Phaseolus vulgaris L. Planta, v.157, p.254- 258,1983. 
LAYZELL, D.B. $\mathrm{N}_{2}$ fixation, $\mathrm{NO}_{3}^{-}$reduction and $\mathrm{NH}_{4}{ }^{+}$assimilation. In: DENNIS, D.T.; TURPIN, D.H. Plant physiology, biochemistry and molecular biology. London: Longman Scientific and Technical, 1990. p.389406.

LEHNINGER, A. L. Bioquímica. São Paulo, Edgard Blucher, 1976. v.3.

LEWIS, O.A.M.; WATSON, E.F.; HEWITT, E.J. Determination of nitrate reductase activity in barley leaves and roots. Annals of Botany, v. 49, p.3137,1982 .

MARSCHNER, H. Mineral nutrition in higher plants: Berlin: Academic Press, 1986. 674p.

MARUN, F. Produção de matéria seca e e nutrição mineral de gramíneas forrageiras em função da relação $\mathrm{Ca} / \mathrm{Mg}$ do corretivo. Lavras, 1990. 81p. Dissertação (M. S.)- Escola Superior de Agricultura de Lavras.

McNALLY, S.F.; ORBANJO, T.O.; HIREL, B.; STEWART, G.R. Glutamine synthetase isoenzymes of Striga hermonthica and other angiosperm root parasites. Journal of Experimental Botany, v.34, p.610-4,1983.

MENGEL.K.: KIRKBY, E. A. Principles of plant nutrition. 4. ed. Bern: Internacional Potash Institute, 1987. 687p. 
MIFLIN, B.J.; LEA, P.J. Ammonia assimilation. In:STUMPF, P.K.; CONN, E.E. (Ed.) The biochemistry of plants. London: Academic Press, 1980. v.5, p.169-202.

MILLS, H, A.; BARKER, A.V.; MAYNARD, D.N. Effects of nitrapyrin on nitrate accumulation in spinach. Journal of the American Society for Horticultural Science, v. 101, p.202-4,1976.

MONTEIRO,F.A. Níveis de cálcio e de magnésio em soja-perene Tinaroo. Piracicaba, 1993. 132p. Tese (Livre Docência)-Escola Superior de Agricultura "Luiz de Queiroz", Universidade de São Paulo.

MONTEIRO, F.A.; WERNER, J. C. Efeitos das adubações nitrogenada e fosfatada em capim-colonião, na formação e em pasto estabelecido. Boletim de Indústria Animal,v. 34, p.91-101,jan./jun. 1977.

MONTEIRO, F. A.; LIMA, S. A. A.; WERNER, J. C.; MATTOS, H.B. Adubação potássica em leguminosas e em capim-colonião (Panicum maximum Jacq.) adubado com níveis de nitrogênio ou consorciado com leguminosas. Boletim de Indústria Animal, v. 37, n.1, p.127- 147, jan./jun.,1980.

MULDER, E. G.; BOXMA, R.; VAN VEEN,W.L. The effect of molybdenum and nitrogen deficiencies on nitrate reduction in plant tissue. Plant and Soil, v.10, p.335-355, 1959. 
OAKS, A.; HIREL, B. Nitrogen metabolism in roots. Annual Review of Plant Physiology, v. 36, p.345- 365, 1985.

OHTA,D.; MATSUI, J.;MATOH,T.; TAKAHASHI,E. Sodium requirement of monocotyledonous $\mathrm{C} 4$ plants for growth and nitrate reductase activity. Plant and Cell Physiology, v.29, p.1429-1432,1988.

O'NEAL,D.; JOY,K.W. Glutamine synthetase of pea leaves. Plant Physiology, v.54, p.773-779, 1974.

PACHECO,O.; PEREZ,D.; FLORES,E. Comparación de fuentes nitrogenadas en la fertilización de la Guinea común (Panicum maximun). Agrotecnia de Cuba, v. 16, p.89-93,1984.

PREMAZZI, L. M. Saturação por bases como critério para recomendação de calagem em cinco forrageiras tropicais. Piracicaba, 1991. 215p. Dissertação (M. S.)- Escola Superior de Agricultura "Luiz de Queiroz", Universidade de São Paulo.

PURCINO, A.A.C.; MAGNAVACA, R.; MACHADO, A.T.; MARRIEL, I.E. Atividade da redutase do nitrato em genótipos antigos e modernos de milho, cultivados sob dois níveis de nitrogênio. Revista Brasileira de Fisiologia Vegetal, v. 6, p.41-46, 1994a. 
PURCINO, A.A.C.; SANTOS, F.G.;SANTOS, M.X.;PAIVA, E.; SILVA, M.R. Atividade da pep-carboxilase e da glutamina sintetase em genótipos de milho e sorgo contrastantes em eficiência de uso de nitrogênio. Revista Brasileira de Fisiologia Vegetal, v.6, p.67-70, 1994b.

QUINN, L. R.; MOTT,G.O.; BISSCHOFF, W. V.A. Fertilização de pastos de capim colonião e produção de carne com novilhos Zebu. New York: IBEC Research Institute, 1961. 40p.

RAIJ,B. van. Fertilidade do solo e adubação. São Paulo: Agronômica Ceres. Associação Brasileira para Pesquisa da Potassa e do Fosfato, 1991. 343p.

RUFTY, T.W.JR.; THOMAS, J.F.; REMMLER, J.L.; CAMPBELL, W.H.; VOLK, R.J. Intercellular localization of nitrate reductase in roots. Plant Physiology, v. 82, p.675-680, 1986.

SANTOS, A.R.; CORRÊA, B.D.; MONTEIRO, F.A. Efeitos de níveis de nitrogênio sobre $\mathrm{o}$ rendimento de matéria seca, teor de nitrogênio e perfilhamento em Panicum maximum cultivar Vencedor. In: CONGRESSO BRASILEIRO DE CIÊNCIA DO SOLO, 25, Viçosa,1995. Resumos expandidos. Viçosa: Sociedade Brasileira de Ciência, 1995. v. 2, p.741-742.

SARRUGE, J. R. Soluções nutritivas. Summa Phytopathologica, v.1, p.231- 233, mar., 1975.

SARRUGE, J. R.; HAAG, H.P. Análises químicas em plantas. Piracicaba: ESALQ, 1974. 56p. 
SAS INSTITUTE INCORPORATION. Proprierty Software Release 6.08. Cary, NC USA, 1989.

SHEN, Z.; LIANG, Y.; SHEN, K. Effect of boron on the nitrate reductase activity in oilseed rape plants. Journal of Plant Nutrition, v.16, p.12291239, 1993.

SILVEIRA, J. S. M. \& SANT'ANNA, R. Efeitos de nitrato e do amônio no crescimento e fracionamento de $\mathrm{N}$ em capim-colonião. Pesquisa Agropecuária Brasileira, v.23, p.135-143, 1988.

SIMÃO NETO, M.; SERRÃO, E.A.S.; GONÇALVES, C.A.; PIMENTEL, D.M. Comportamento de gramíneas forrageiras na região de Belém. Belém:IPEAN, 1973. 17p. (Circular Técnico, 44).

SRIVASTAVA, H. S. Regulation of nitrate reductase activity in higher plants. Phytochemistry, v.19, p. 725-733, 1980.

TAIZ, L.; ZIEGER, E. Plant physiology. Redwood City: The Benjamin/Cumminggs Publishing Company, 1991. cap 12: Assimilation of mineral nutrients, p.292-317.

VANGE, C.P.; GRIFFTH, S.M. The molecular biology of N metabolism. In: DENNIS, D.T.; TURPIN, D.H. Plant physiology, biochemistry and molecular biology. London: Longman Scientific and Technical, 1990. p.37388. 
WERNER, J. C.; HAAG, H. P. Estudos sobre a nutrição mineral de alguns capins tropicais. Boletim de Indústria Animal, v.29, p.191- 245,1972.

WERNER, J. C.;QUAGLIATO, J. L.;MARTINELLI,D. Ensaio de fertilização do colonião com solo de Sertãozinho. Boletim de Indústria Animal, v.24, p.155-158, 1967.

YONEYAMA, T.; YAMADA, H.; YAMAGATA, M.; KOUCH, H. Nitrate reduction and partioning of nitrogen in komatsuna (Brassica campestris L. var. rapa) plants: compartmental analysis in combination with ${ }^{15} \mathrm{~N}$ tracer experiments. Plant Cell Physiology, v.28, p.679-96, 1989.

ZIMMERMAN, M. Magnesium in plants. Soil Science, v.63, p.1- 12,1947.

ZINK, M.W. Regulation of ammonia-assimilation enzymes by various nitrogen sources in cultured Ipomoea spp. Canadian Journal of Botany, v.67, p.3127-3133, 1989. 